\title{
Working time preferences
}

Citation for published version (APA):

Loog, B. (2014). Working time preferences. [Doctoral Thesis, Maastricht University]. Maastricht University. https://doi.org/10.26481/dis.20141114bl

Document status and date:

Published: 01/01/2014

DOI:

$10.26481 /$ dis.20141114bl

Document Version:

Publisher's PDF, also known as Version of record

\section{Please check the document version of this publication:}

- A submitted manuscript is the version of the article upon submission and before peer-review. There can be important differences between the submitted version and the official published version of record.

People interested in the research are advised to contact the author for the final version of the publication, or visit the DOI to the publisher's website.

- The final author version and the galley proof are versions of the publication after peer review.

- The final published version features the final layout of the paper including the volume, issue and page numbers.

Link to publication

\footnotetext{
General rights rights.

- You may freely distribute the URL identifying the publication in the public portal. please follow below link for the End User Agreement:

www.umlib.nl/taverne-license

Take down policy

If you believe that this document breaches copyright please contact us at:

repository@maastrichtuniversity.nl

providing details and we will investigate your claim.
}

Copyright and moral rights for the publications made accessible in the public portal are retained by the authors and/or other copyright owners and it is a condition of accessing publications that users recognise and abide by the legal requirements associated with these

- Users may download and print one copy of any publication from the public portal for the purpose of private study or research.

- You may not further distribute the material or use it for any profit-making activity or commercial gain

If the publication is distributed under the terms of Article $25 \mathrm{fa}$ of the Dutch Copyright Act, indicated by the "Taverne" license above, 


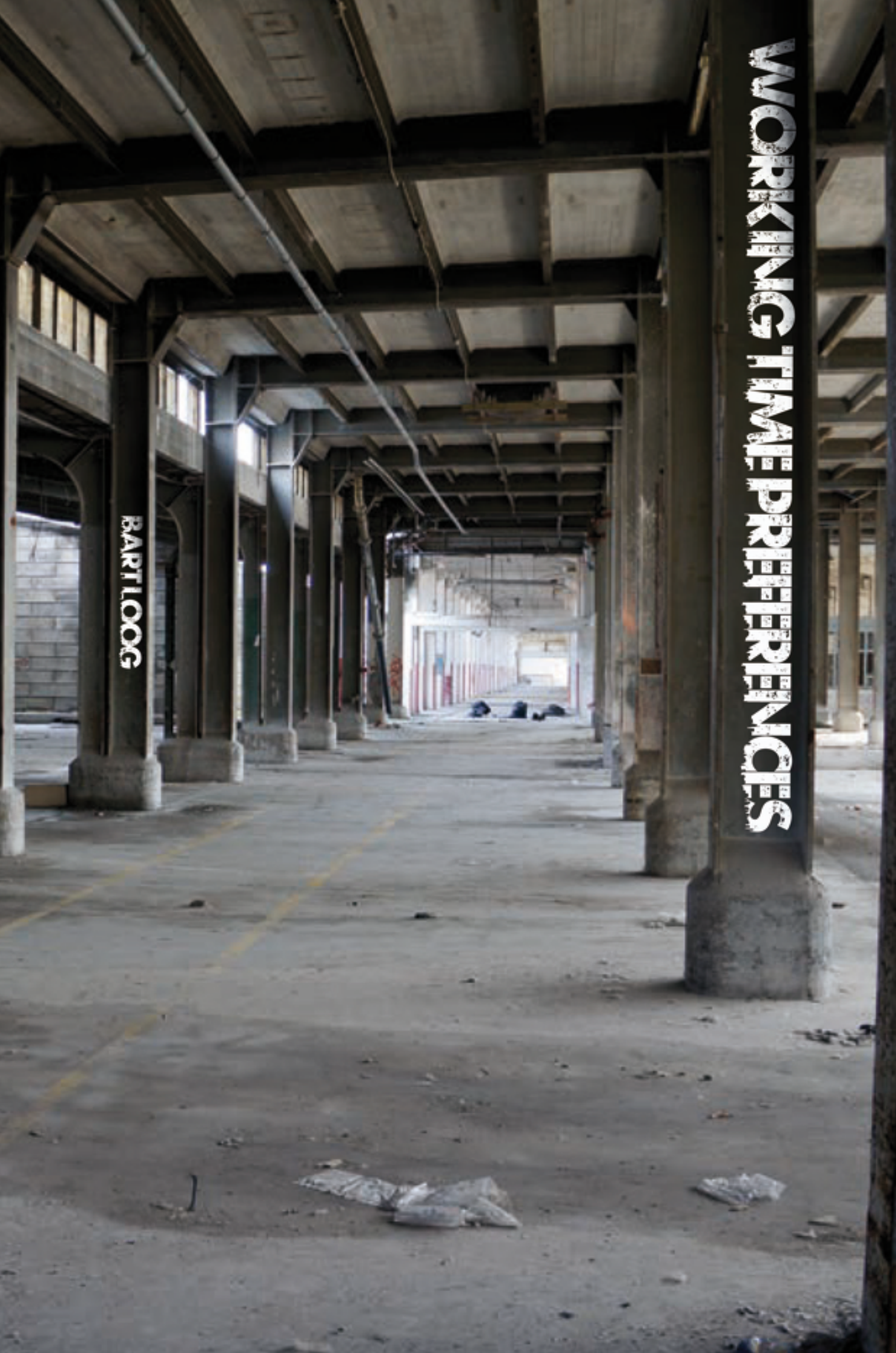


Copyright (c)Bart Loog, Heerlen 2014

All rights reserved. No part of this publication may be reproduced, stored in a retrieval system, or transmitted, in any form, or by any means, electronic, or mechanical, including photocopying, recording or otherwise, without prior permission in writing from the author.

This book was typeset by the author using $\mathrm{LAT}_{\mathrm{E}} \mathrm{X}$.

Cover by Linda and Paul Küsters

Published by Datawyse - Universitaire Pers Maastricht

ISBN 978-94-6159-367-2 


\title{
Working time preferences
}

\author{
DISSERTATION \\ to obtain the degree of Doctor at Maastricht University, \\ on the authority of the Rector Magnificus, \\ Prof. dr. L.L.G. Soete \\ in accordance with the decision of the Board of Deans, \\ to be defended in public \\ on Friday November 14, 2014, at 14:00 hours
}

by

Bart Loog

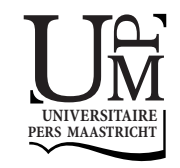




\section{Supervisor:}

Prof. dr. Thomas Dohmen

\section{Co-supervisor:}

dr. Maarten Vendrik

\section{Assessment Committee:}

Prof. dr. Lex Borghans (chair)

Prof. dr. Arie Kapteyn (University of Southern California)

Prof. dr. Gerard Pfann

I thank the Maastricht Research School of Economics of Technology and Organizations (METEOR) for financial support. 


\section{Acknowledgements}

I would like to thank Thomas and Maarten for all their encouragement and discussions throughout my $\mathrm{PhD}$. Thomas, your advice on how to position a paper, and 'write down' research, were - and still are - invaluable. Maarten, I mostly harassed you with all my questions, and I want to thank you for the fact that your door was always open. I would also like to thank the assessment committee (Lex Borghans, Arie Kapteyn and Gerard Pfann) for their efforts and comments.

For many work-related discussions, coffee-breaks, lunches, watching funny movies, and attempts to play football in office every now and then, I thank Ehsan, Lennart, Norbert, Ron, Ulf, and Mona. I also thank Tyas, for all the above + for supporting me during the finishing stages of writing the dissertation. Tyas and Ehsan, thank you for being my paranymphs.

Another warm 'thank you' goes out to the ladies of the A0 wing. Fleur, Silvana and Sylvia, thank you for having an occasional chat, listening to my stories (about a broken car on the way to Bruges, looking for a new apartment, looking for a job, etcetera), answering all my questions regarding administrative matters, and for the almost unlimited supply of nice candy and cookies every single day of the week.

Thank you, Linda, for putting up with all evenings and weekends I spent in front of my laptop, for believing in me when I didn't, and for your love. I am lucky to have you at my side on numerous holidays, city-trips, and strolls across the Brunsummerheide and 6417, and - in general - in my life.

Finally, I want to thank my big brothers Marco and Tom, and my parents Ad and Toos, for a carefree childhood and for their support in making study-related, work-related, and all kinds of other choices in life.

\section{Bart Loog, Heerlen, October 2014}





\section{Contents}

2 Working longer or shorter hours:

Heterogeneity among working women 5

2.1 Introduction . . . . . . . . . . . . . . . . . 5

2.2 Data . . . . . . . . . . . . . . . . . . 6

2.2.1 Actual and preferred hours . . . . . . . . . . . . . 7

2.2.2 Background characteristics ............ . . 8

2.3 Regression analysis . . . . . . . . . . . . . . . . . . . 11

2.4 Policy . . . . . . . . . . . . . . . . . . 16

2.5 Conclusion . . . . . . . . . . . . . . . . 17

3 The scope for increasing total hours worked $\quad 19$

3.1 Introduction . . . . . . . . . . . . . . . . . . . . . . . 19

3.2 Data . . . . . . . . . . . . . . . . . . 21

3.3 Discrepancy between actual and preferred hours . . . . . . . . . . 22 
3.4 Estimation . . . . . . . . . . . . . . . . . . 24

3.5 Results . . . . . . . . . . . . . . . . . 26

3.5.1 Heterogeneity between segments . . . . . . . . . . . 26

3.5.2 Heterogeneity within segments . . . . . . . . . . . . . . 29

3.6 Concluding remarks . . . . . . . . . . . . . . . . . . . . . . . 33

4 The impact of changes in the standard workweek on preferences for labor supply

4.1 Introduction . . . . . . . . . . . . . . . . . . . . . . . . . . 35

4.2 Data . . . . . . . . . . . . . . . . 36

4.3 Assignment to standard-hours regime . . . . . . . . . . . . . . . . 39

4.4 Descriptive evidence for preference adjustment . . . . . . . . . . . 40

4.4.1 Reductions in the length of the standard workweek . . . . . 41

4.4.2 Extensions of the standard workweek . . . . . . . . . . . . . 44

4.4.3 Reductions and extensions quantified . . . . . . . . . . . 44

4.5 Augmented standard labor supply model . . . . . . . . . . . . . . . 44

4.6 Results . . . . . . . . . . . . . . . . . . . . 46

4.7 Robustness ...................... 50

4.7.1 Changes in the standard workweek and the unemployment rate 50

4.7.2 Selectivity: Leaving the civil service after workweek extension? 51

4.7.3 Wage endogeneity . . . . . . . . . . . . . 51

4.8 Discussion of results: Reference effects . . . . . . . . . . . . . . . 53

4.9 Summary and concluding remarks . . . . . . . . . . . . . . . . 55

$5 \quad$ Interdependent preferences in labor supply $\quad 57$

5.1 Introduction . . . . . . . . . . . . . . . . 57

5.2 Literature . . . . . . . . . . . . . . . . . . . . . . . 58

5.3 Identification of interdependent preferences . . . . . . . . . . . . 59

5.4 Data . . . . . . . . . . . . . . . . . 61

5.5 Results . . . . . . . . . . . . . . . . . 63

5.6 Validity of the exclusion restriction of the instrumental variable . . 64

5.7 Discussion and concluding remarks . . . . . . . . . . . . . . . 66

$\begin{array}{lll}6 & \text { Conclusion and discussion } & 69\end{array}$

6.1 Chapter $2 \ldots \ldots \ldots$. . . . . . . . . . . . . . . . . 69

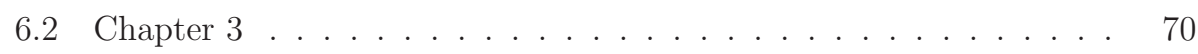

6.3 Chapter $4 \ldots \ldots \ldots 71$ 
6.4 Chapter $5 \ldots \ldots \ldots \ldots$. . . . . . . . . . . . . . . 72

Bibliography

Samenvatting (Summary in Dutch)

Curriculum Vitae 



\section{List of Figures}

2.1 Preferred working hours per week. . . . . . . . . . . . . 8

3.1 Actual weekly working hours . . . . . . . . . . . . . 24

3.2 Equilibrium hours of work . . . . . . . . . . . . . 25

3.3 Heterogeneity in the "equilibrium hours of work" . . . . . . . . 26

4.1 Length of the standard workweek for civil servants and public sector employees in West-German federal states . . . . . . . . . . . 38

4.2 Series of standard, actual, contractual and preferred weekly hours, by gender . . . . . . . . . . . . . . . . . . . . . 42

4.3 The effects of a shortening and lengthening of the standard workweek 43

4.4 The effects of a shortening and lengthening of the standard workweek 49

5.1 Length of the standard workweek for civil servants in West-German federal states. . . . . . . . . . . . . . . . . . . 61 



\section{List of Tables}

2.1 Summary statistics . . . . . . . . . . . . . . . . 9

2.1 Summary statistics 2010-wave (continued from previous page) . . 10

2.2 Regression results . . . . . . . . . . . . . . . . . . 12

2.2 Regression results (continued from previous page) . . . . . . 13

3.1 Summary statistics . . . . . . . . . . . . . . . . . . 23

3.2 Regression results . . . . . . . . . . . . . . . . . . 27

3.2 Regression results (continued from previous page) . . . . . . . 28

3.2 Regression results (continued from previous page) . . . . . . . . 29

3.3 Results from the LFS . . . . . . . . . . . . . . . . . . . 31

3.4 Predicting the desired change in working hours $(\mathrm{hm}) \ldots \ldots$

4.1 Length of the standard workweek . . . . . . . . . . . 37

4.2 Length of the standard workweek for employees in public service at the federal and municipal level. . . . . . . . . . . . . . . 40

4.3 The effect of changes in the standard workweek . . . . . . . . . 45

4.4 Main results . . . . . . . . . . . . . . . . . 47

4.4 Main results (continued from previous page) . . . . . . . . 48

4.5 Results from standard model including the unemployment rate . . 53

5.1 Length of the standard workweek of civil servants . . . . . . . 62

5.2 Results . . . . . . . . . . . . . . . . . 65 



\section{Introduction}

The number of activities one can undertake is almost infinite. The amount of time an individual has at his disposal is not, however. Therefore, individuals have to choose how much time to spend on each of these activities. For a labor economist the model is simpler: individuals either enjoy leisure time or they spend time working for an income. The income earned is used to buy consumption goods. That is, people essentially face a trade-off between enjoying leisure time and buying consumption goods. For a given wage rate, some prefer to have a lot of leisure time, work short hours and buy few consumption goods. Others prefer to work long hours, have few holidays a year and buy a lot of consumption goods.

In neoclassical theory these differences in labor supply are explained by differences in earning capacity, other income, and preferences for leisure and commodity goods. That is, the optimal combination of buying consumption goods and having leisure time in the labor-consumption schedule is affected by (i) a rotation of the budget constraint following a change in the wage rate, (ii) a shift of the budget constraint following a change in other income, and (iii) preferences. That is, agents facing a similar wage rate and enjoying the same level of other income may still end up at different optima when they value consumption goods and leisure time differently (Killingsworth, 1983, p.10).

Within the framework of neoclassical theory, empirical research has shown that factors other than those captured by this simple model affect labor supply decisions. Examples are differences in family size (Angrist and Evans, 1998) and the availability and costs of child care (Attanasio et al., 2008; Del Boca and Vuri, 2007). Yet, the analysis of labor supply - estimating the effect of changes in explanatory 
variables on labor supply - is subject to more challenges, two of which are the subject of this thesis.

First, there are discrepancies between actual and preferred working hours, which may complicate the effects of a change in the wage rate on working hours (see Kahn and Lang, 1991). Several studies document these discrepancies. ${ }^{1}$ Moreover, there is suggestive empirical evidence that there exists heterogeneity in these discrepancies among working women in the Netherlands (Booth and Van Ours, 2013; Keuzenkamp et al., 2009; Portegijs et al., 2008). However, there is no study that systematically investigates these discrepancies. As such, little is known about the relation between the desire to change working hours and individual background characteristics of working Dutch women. This is the first main issue we tackle in this thesis.

Second, preferences for work and leisure may change over time. Individual preferences might, for example, be subject to habit formation, such that preferences change according to one's behavior (e.g. Bover, 1991; Vendrik, 1993). Preferences may also evolve over time for other reasons, such as changing social norms (e.g. Fernández, 2013; Fogli and Veldkamp, 2011), or because individuals' preferences are affected by the behavior of others (Blomquist, 1993; Woittiez and Kapteyn, 1998). Researchers who want to identify these reference effects face certain problems. In the case of interdependent preferences for work and leisure, i.e. the effect of someone's labor supply behavior on someone else's preferences, it is common to relate individual working hours to the average hours worked in a certain reference group. However, there is no guarantee that the variation in the average working hours of the reference group is a legitimate source of variation for identifying preference interdependence. Variation in this average only identifies preference interdependence if it is not driven by factors that also directly affect the individual's preferred hours. For example, a sudden increase in the workload that causes an increase in hours worked across the board might affect everybody's preferred hours (e.g. through habit formation), and would hence introduce a spurious correlation between average hours and individual preferred hours.

The analysis of habit formation - the effect of past behavior on current preferences - faces a similar problem. ${ }^{2}$ Explaining current behavior by lagged behavior in an individual-fixed-effects model introduces a correlation between the independent variable of interest and the residual. In order to properly investigate the existence of reference effects like the ones mentioned here, we ideally need some source of exogenous variation. This is the second main issue addressed in this thesis.

In Chapters 2 and 3, we investigate the heterogeneity in the desire to change the weekly working hours among working women in the Netherlands. In Chapters 4 and 5, we analyze to what extent labor supply preferences are subject to reference

\footnotetext{
${ }^{1}$ Examples are Euwals (2001) and Euwals and Van Soest (1999) for the Netherlands, Kahn and Lang (1995) and Barrett and Doiron (2001) for Canada, Stewart and Swaffield (1997) and Böheim and Taylor (2004) for Britain, and Holst (2009) for Germany.

${ }^{2}$ See for example Bover (1991) and Hotz et al. (1988).
} 
effects, making use of a policy change that affected the standard workweek for a particular group of employees.

Several studies have uncovered discrepancies between actual and preferred working hours among working women in the Netherlands. In Chapter 2 we add to the previous literature by presenting an integrated analysis of the determinants of these discrepancies. Specifically, we carry out a regression analysis with the desired change in weekly working hours as the dependent variable and several individual background, demographic and financial characteristics, and satisfaction measures as independent variables.

The results from the heterogeneity analysis indicate that there is a sizable group of part-time-working women who would like to increase their weekly working hours, mainly women who perform semi- or unskilled manual labor and women with lower educational attainment. At the same time, a substantial number of working women would prefer to reduce the number of weekly working hours. Relatively many highly educated women are in the latter group. On the basis of these results we hint at policy implications and suggest it might be possible to increase working hours when policy is aimed towards those already willing to increase their weekly hours.

In Chapter 3 we examine how women's desire to work fewer or more hours varies between and within segments of the labor market. We calculate the number of hours beyond which there is, on average, a tendency to prefer a decrease in hours worked. This point is allowed to vary with background characteristics. We then investigate which proportion of each group that works more than this particular number of hours. This proportion is an indication of how many women with a particular set of characteristics are expected to prefer to work less.

The results indicate that this 'equilibrium' point where average actual and preferred working hours are equal depends on individual characteristics. Given that this point differs between groups of individuals, we show that the relative sizes of the groups working longer and shorter hours differ between groups.

In Chapter 4 we analyze whether reference points affect labor supply decisions. Several theories build on the idea that reference points affect preferences for work and leisure. Examples of such reference effects are preference interdependence (e.g., Blomquist, 1993), habit formation (e.g., Vendrik, 1993), internalization of a social norm (e.g., Grodner and Kniesner, 2006) and anchoring (Tversky and Kahneman, 1974). Using data from the German Socio-Economic Panel Study we analyze whether preferences for work and leisure are affected by such reference effects. We exploit arguably exogenous changes in the length of the standard workweek of (former) West German civil servants (Beamte) and public sector employees (Angestellte im offentlichen Dienst) and investigate whether the preferred number of hours worked changes in response to reductions and extensions in the length of the standard workweek. In particular, we estimate a standard labor supply model in which we model an individual's preferred working hours as a function of the 
standard working time and conventional determinants of labor supply.

We find that the variations in the standard workweek significantly and strongly affect the preferences for weekly working hours. A reduction in the standard workweek was followed by a strong contemporaneous decrease in preferred hours. However, in subsequent years preferences partly reverted back to the old level, such that the long-run effect was smaller than the short-run effect. A workweek extension led to a gradual increase in preferred weekly working hours over time. That is, we find an asymmetry in the adjustment process of preferred labor supply for extensions and reductions of standard working hours.

The analysis in Chapter 4 leaves unanswered how preferences are shaped. One of the potential channels is preference interdependence with respect to hours worked. That is, individuals may prefer to work longer hours following an increase in the standard working time because they observe their co-workers working longer hours. In Chapter 5 we attempt to isolate the effect of the labor supply decisions by colleagues on someone's individual labor supply preferences. We assess empirically whether an increase in the average hours worked by colleagues, induced by an extension of the standard workweek, leads to an increase in the preferred working hours of people unaffected by this policy.

The results suggest that the changes in standard and average hours worked of civil servants significantly impacted the preferred hours of public sector employees. A one-hour increase in the average hours worked by civil servants increases desired hours of public sector employees by about two-thirds of an hour. We also estimate a reduced-form model. Results from this model indicate that a one-hour increase in the standard workweek of civil servants leads to a fifteen-minute increase in the preferred working hours of (former) West German public sector employees. 


\section{Working longer or shorter hours: Heterogeneity among working women ${ }^{1}$}

\section{$2.1 \quad$ Introduction}

Compared to other countries in the European Union, there are many women in paid employment in the Netherlands. Yet, the vast majority of Dutch women works in part-time jobs (Statistics Netherlands, 2009). The part-time nature of female employment in the Netherlands has long been an issue debated by policy makers as well as academics. ${ }^{2}$ In an attempt to (1) address the effects of the aging population - the rising cost of the welfare state and the decreasing potential labor force and to (2) reduce the financial dependency of wives on their husbands, the Dutch government founded the Task Force Part-time Plus in 2008. The Task Force's goal was to increase female employment in the Netherlands in terms of working hours (Ministry of Social Affairs, 2008).

Given the part-time nature of female employment and the changing demographic composition of the potential work force it is not surprising that many recent studies investigate the labor supply preferences of Dutch women. In this chapter we provide more insight into the size of discrepancies between the preferred and actual working hours and investigate whether individual characteristics are related to the preferred change in weekly working hours. In light of the attempts to raise participation of working women, we investigate whether it is possible to increase working hours

\footnotetext{
${ }^{1}$ This chapter is based on joint work with Thomas Dohmen and Maarten Vendrik. It concerns a revised and translated version of a paper that is published in TPEdigitaal (Loog et al., 2011).

${ }^{2}$ See for example Bosch et al. (2010), Booth and Van Ours (2013) and TPEdigitaal 3(2).
} 
among working women, taking as a starting point the preferences for hours worked under current conditions. The results highlight the importance of heterogeneity, which has implications for policy aimed at increasing working hours.

Several studies examine the labor supply preferences of working women in the Netherlands. Keuzenkamp et al. (2009) analyze preferences of women working in jobs of a maximum of 24 hours a week. The authors show that these women would, on average, prefer a two-hour increase in their weekly working time. Portegijs et al. (2008) show that most women who work long hours actually prefer working fewer hours. The authors also show that a fraction of the female work force would like to increase hours under improved working conditions (e.g. being able to work from home more often) and discuss the characteristics of only this group. ${ }^{3}$ Cloï (2010) focuses on labor supply decisions of mothers and shows that highly educated mothers make similar trade-offs with respect to the length of their workweek as mothers with lower educational attainment. Yet, a higher fraction of the highly educated mothers would prefer to work less, while a higher fraction of less educated mothers would prefer to work more. These studies uncover discrepancies between actual and preferred working hours. ${ }^{4}$ We augment this literature by presenting an integrated analysis of the determinants of these discrepancies for all working Dutch women.

In the next section we present data that show considerable heterogeneity among working women with respect to the desired change in working hours. In Section 2.3 we investigate how background characteristics correlate with the discrepancy between actual and preferred hours. In Section 2.4 we discuss policy implications, and propose a policy measure that could partly resolve this discrepancy. Section 2.5 concludes.

\subsection{Data}

The data used in this chapter come from the Longitudinal Internet Studies for the Social sciences (LISS), a representative, probability-based internet panel (Scherpenzeel, 2011). The data we use contain information on 4,568 observations of 2,285 women aged between 16 and 59 (inclusive) who were in gainful employment for at least one year in the 2008-2010 period. The main variables of interest in

\footnotetext{
${ }^{3}$ In Portegijs et al. (2008) respondents are first asked to state their preferred hours: "If you yourself would be able to decide, how many hours per week would you like to work? Please, take into account the financial consequences of your decision." Afterwards individuals are asked what conditions must be fulfilled such that the respondent will start working these statedpreferred hours, implying that the first question does not ask for preferred hours under the current circumstances, but under ideal conditions (e.g. being able to arrange child care).

${ }^{4}$ Differences between actual and preferred working hours can be explained theoretically. Becker (1971) and Hashimoto (1981) provide an explanation based on firm-specific human capital. Lazear $(1979,1981)$ explains the discrepancy using principal-agent theory. Kahn and Lang (1992) test both theories and do not find empirical support for either of these theoretical arguments.
} 
2 Working longer or shorter hours: Heterogeneity among working women

the current study are the actual and preferred weekly working hours $(h$ and $h p$ respectively). ${ }^{5}$ Besides information on (preferred) labor supply we have data on demographic and socio-economic background characteristics. We restrict the sample to women who work as employees and who are not in full-time education. ${ }^{6}$

We combine information from separate questions related to working hours, one for average weekly working hours in the main job and one for hours in any potential second job. The wording of the question concerning working hours in the main job is as follows: "How many hours per week do you actually work in your job, on average? If you have multiple jobs, please report the number of hours worked in your main job. Whether overtime is paid or not is irrelevant." The wording of the question concerning working hours in a potential second job: "How many hours per week do you usually work in your additional job?". The wording of the question concerning the preferred working hours per week is as follows: "How many hours per week would you like to work? Please consider the hours worked in all of your jobs combined". ${ }^{7}$ We assume that the question concerning preferred hours $h p$ is answered for the current job(s). ${ }^{8}$

\subsubsection{Actual and preferred hours}

Of the 1,443 employed female respondents in the 2010 wave of the LISS, most work 24 hours per week (10.4 percent), followed by the groups working 40, 32 and 20 hours per week $\left(9.8,8.7\right.$ and 6.9 percent respectively). ${ }^{9}$ As shown in Figure 2.1, jobs with a 32-hour workweek are most popular (17 percent). Jobs of 24 and 20 hours rank second and third (15.5 and 11.7 percent respectively). Only 8 percent of the working women prefer to work 40 hours per week. Roughly 44 percent of the

\footnotetext{
${ }^{5}$ The predictive power of preferred weekly working hours has been evaluated by Euwals et al. (1998). The authors show that - in addition to qualitative information - including preferred hours information in their model helps predicting future actual hours.

${ }^{6} \mathrm{We}$ also exclude women who receive disability benefits, women with a net hourly wage of over 100 euros, women with a net monthly labor income of over 12,000 euros and women whose other household income exceeds 12,000 euros.

${ }^{7}$ The original wording of the Dutch questions is: "Hoeveel uur per week werkt $\mathrm{u}$ gemiddeld in werkelijkheid in uw baan? Hebt $\mathrm{u}$ meerdere banen neem dan de voor $\mathrm{u}$ belangrijkste baan. Of overuren al dan niet betaald worden doet niet terzake" and "Hoeveel uur per week werkt u gewoonlijk in deze bijbaan of tweede werkkring?" and "Hoeveel uren per week zou u in totaal willen werken? Het gaat om het aantal uren in alle banen die u hebt, bij elkaar genomen".

${ }^{8}$ This assumption seems to be justified by the setup of the questionnaire. Before respondents are asked for their preferred weekly working hours, they are asked whether they want to have "other or more work". Because of the wording of the question we are unable to tell whether an individual who answers with "yes" wants another job, more work, or both. In any case, only about 5 percent of the sample answered "yes" to this question, and excluding them from the analysis neither alters the main results nor the conclusions.

${ }^{9}$ The high degree of heterogeneity in the length of the workweek is typical for the Dutch labor market and the flexibility that is implied may be the reason why so many women are working, as suggested by the work of Van Lomwel and Van Ours (2005) and Gregory and Connolly (2008, p.F52).
} 


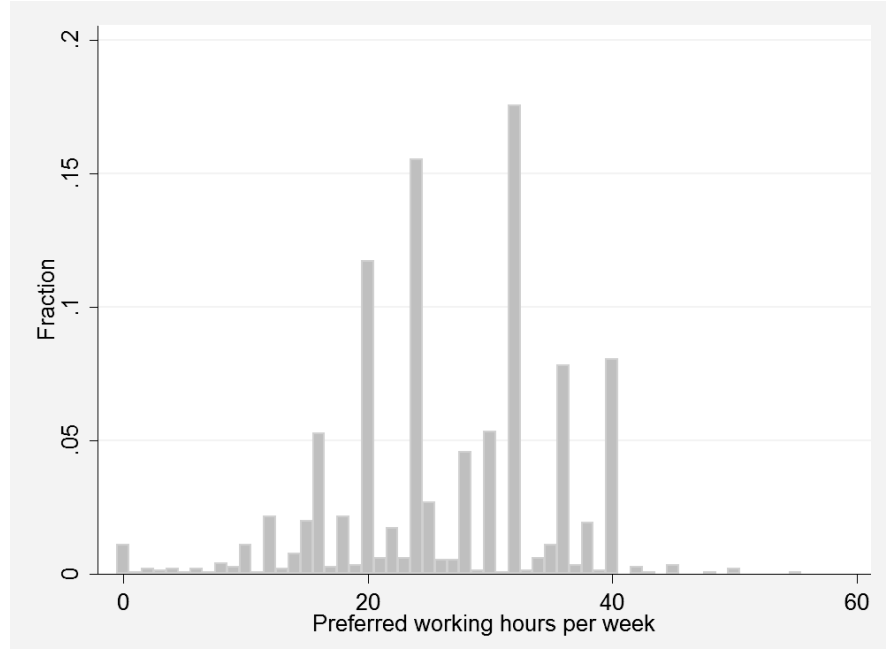

Figure 2.1: Preferred working hours per week.

Note: Presented numbers are based on survey responses in the 2010-wave of the LISS panel.

women in the sample want to work less than they currently do. Only 18 percent would like to increase their weekly working hours. The remaining 38 percent do not desire a change in weekly hours. On average, the difference between preferred and actual hours amounts to negative 2.1. That is, women would like to work significantly less: 26.6 hours instead of their current 28.7 hours.

\subsubsection{Background characteristics}

In Table 2.1 we split the sample into three groups, depending on whether and how individual women would like to change their weekly working hours. Background characteristics of women who want to work shorter $(h p<h)$ and longer $(h p>h)$ hours can be found in columns (1) and (3) respectively. Background characteristics of women who do not want to change weekly hours $(h p=h)$ are presented in column (2). In column (4) we indicate whether there is a significant difference between the averages (or percentages) in columns (1) and (3). That is, we investigate whether those who want to work shorter and longer hours differ significantly with respect to background characteristics. 
2 Working longer or shorter hours: Heterogeneity among working women

Table 2.1: Summary statistics

\begin{tabular}{|c|c|c|c|c|}
\hline Condition on preferred hours & $\begin{array}{c}(1) \\
h p<h\end{array}$ & $\begin{array}{c}(2) \\
h p=h\end{array}$ & $\begin{array}{c}(3) \\
h p>h\end{array}$ & $\begin{array}{c}(4) \\
(1)-(3)\end{array}$ \\
\hline \multicolumn{5}{|l|}{ Hours } \\
\hline Actual hours $(h)$ & $\begin{array}{c}34.2 \\
(9.8)\end{array}$ & $\begin{array}{l}26.1 \\
(8.5)\end{array}$ & $\begin{array}{l}20.7 \\
(8.7)\end{array}$ & $* * *$ \\
\hline Preferred hours $(h p)$ & $\begin{array}{l}26.7 \\
(9.2)\end{array}$ & $\begin{array}{l}26.1 \\
(8.5)\end{array}$ & $\begin{array}{l}27.3 \\
(8.5)\end{array}$ & \\
\hline Preferred change in actual hours $(\mathrm{hm})$ & $\begin{array}{l}-7.5 \\
(6.3)\end{array}$ & $\begin{array}{l}- \\
-\end{array}$ & $\begin{array}{c}6.6 \\
(5.2)\end{array}$ & $* * *$ \\
\hline \multicolumn{5}{|c|}{ Educational attainment } \\
\hline Primary or no education & $1 \%$ & $3 \%$ & $3 \%$ & \\
\hline Preparatory secondary vocational education & $11 \%$ & $22 \%$ & $30 \%$ & $* * *$ \\
\hline Senior general secondary- or pre-university education & $9 \%$ & $7 \%$ & $11 \%$ & \\
\hline Basic vocational training & $25 \%$ & $39 \%$ & $31 \%$ & * \\
\hline Higher professional education & $38 \%$ & $21 \%$ & $18 \%$ & $* * *$ \\
\hline Academic higher education & $13 \%$ & $5 \%$ & $5 \%$ & $* * *$ \\
\hline \multicolumn{5}{|c|}{ Demographics } \\
\hline Age & $\begin{array}{c}41.1 \\
(10.4)\end{array}$ & $\begin{array}{c}43.0 \\
(10.3)\end{array}$ & $\begin{array}{c}41.6 \\
(10.1)\end{array}$ & \\
\hline Number of children living in the household & $\begin{array}{c}1.0 \\
(1.1)\end{array}$ & $\begin{array}{c}1.2 \\
(1.1)\end{array}$ & $\begin{array}{c}1.3 \\
(1.2)\end{array}$ & $* * *$ \\
\hline Married & $52 \%$ & $66 \%$ & $58 \%$ & \\
\hline Divorced & $10 \%$ & $10 \%$ & $12 \%$ & \\
\hline Cohabiting, no children in household & $31 \%$ & $28 \%$ & $24 \%$ & ** \\
\hline Cohabiting with children in household & $43 \%$ & $54 \%$ & $52 \%$ & ** \\
\hline Single, no children in household & $19 \%$ & $11 \%$ & $13 \%$ & $*$ \\
\hline Single with children in household & $7 \%$ & $7 \%$ & $11 \%$ & $*$ \\
\hline \multicolumn{5}{|c|}{ Type of job and sector } \\
\hline Semi- or unskilled manual work & $6 \%$ & $15 \%$ & $21 \%$ & $* * *$ \\
\hline Health and welfare & $30 \%$ & $35 \%$ & $35 \%$ & \\
\hline Government services and public administration & $8 \%$ & $9 \%$ & $6 \%$ & \\
\hline Business services & $8 \%$ & $5 \%$ & $4 \%$ & $* * *$ \\
\hline Financial services & $5 \%$ & $5 \%$ & $2 \%$ & $* *$ \\
\hline Utilities production, distribution and/or trade & $0 \%$ & $1 \%$ & $0 \%$ & \\
\hline Education & $20 \%$ & $7 \%$ & $8 \%$ & $* * *$ \\
\hline Retail trade & $5 \%$ & $10 \%$ & $10 \%$ & $* * *$ \\
\hline Industrial production & $4 \%$ & $3 \%$ & $3 \%$ & \\
\hline Construction & $1 \%$ & $2 \%$ & $1 \%$ & \\
\hline Catering & $2 \%$ & $2 \%$ & $5 \%$ & ** \\
\hline Transport, storage and communication & $2 \%$ & $3 \%$ & $2 \%$ & \\
\hline Environmental services, culture recreation & $2 \%$ & $2 \%$ & $3 \%$ & \\
\hline Other sectors & $11 \%$ & $15 \%$ & $18 \%$ & ** \\
\hline Has multiple jobs & $7 \%$ & $3 \%$ & $10 \%$ & * \\
\hline \multicolumn{5}{|c|}{ Financial information (Net, in euros) } \\
\hline Wage rate & $\begin{array}{l}11.29 \\
(4.71)\end{array}$ & $\begin{array}{l}11.24 \\
(3.56)\end{array}$ & $\begin{array}{l}11.88 \\
(8.90)\end{array}$ & \\
\hline Wage (without 10\% extremes) & $\begin{array}{l}10.96 \\
(2.33)\end{array}$ & $\begin{array}{l}10.97 \\
(2.16)\end{array}$ & $\begin{array}{l}10.64 \\
(2.92)\end{array}$ & \\
\hline Personal income of non-cohabiting respondents & $\begin{array}{l}1,879 \\
(665)\end{array}$ & $\begin{array}{l}1,608 \\
(559)\end{array}$ & $\begin{array}{l}1,261 \\
(417)\end{array}$ & $* * *$ \\
\hline
\end{tabular}

Continued on next page 
Table 2.1: Summary statistics 2010-wave (continued from previous page)

\begin{tabular}{lcccc}
\hline \multirow{2}{*}{ Condition on preferred hours } & $(1)$ & $(2)$ & $(3)$ & $(4)$ \\
& $h p<h$ & $h p=h$ & $h p>h$ & $(1)-(3)$ \\
\hline Personal income of cohabiting respondent & 1,537 & 1,184 & 877 & $* * *$ \\
Other income of cohabiting respondents & $(606)$ & $(475)$ & $(450)$ & \\
& 2,165 & 2,170 & 2,120 & \\
Wage & $(1,033)$ & $(988)$ & $(978)$ & \\
Satisfaction with job aspects & & & $* *$ \\
Working hours & 6.8 & 6.9 & 6.2 & $* * *$ \\
Type of job & $(1.7)$ & $(1.7)$ & $(2.1)$ & $* * *$ \\
& 7.2 & 7.9 & 7.5 & $* * *$ \\
Atmosphere & $(1.7)$ & $(1.4)$ & $(1.6)$ & $* * *$ \\
Career & 7.5 & 7.8 & 7.0 & \\
& $(1.5)$ & $(1.4)$ & $(2.0)$ & \\
Current job & 7.5 & 7.8 & 7.5 & \\
Amount of leisure & $(1.5)$ & $(1.3)$ & $(1.6)$ & $* * *$ \\
& 7.2 & 7.5 & 6.6 & \\
& $(1.4)$ & $(1.3)$ & $(2.0)$ & $* * *$ \\
Number of observations & 7.3 & 7.7 & 6.9 & \\
\hline
\end{tabular}

Note: Descriptive statistics of working women for different conditions on preferred and actual working hours. In column (1) we present the characteristics of women who would like to work shorter hours, column (2) for those who do not want to change working hours and column (3) for those who want to work longer hours. Presented numbers are based on survey responses in the 2010-wave of the LISS panel. Standard deviations are presented in parentheses.

Table 2.1 reveals differences between women who want to work longer and those who want to work shorter hours. In the first panel, we show information on the actual and preferred weekly working hours. Those willing to decrease working hours are concentrated in jobs with relatively long hours, whereas those who want to work more are predominantly in part-time jobs and currently work relatively few hours a week. ${ }^{10}$ Even though the groups differ significantly with respect to many characteristics, there is no significant difference between the preferred weekly working hours of the two groups. This suggests a strong tendency, on average, for Dutch women to prefer a part-time job (see also Booth and Van Ours, 2013).

The majority of women who prefer to reduce working hours graduated from university (academic higher education) or graduated from hbo (higher professional education). These education categories seem to be relatively over-represented in this group, compared to women who would like to work longer hours. Indeed, relatively many women who prefer to work more have below-average educational attainment. We find a similar pattern for the percentage of women performing semi- or low-skilled manual labor. The desire to increase or reduce the number of

\footnotetext{
${ }^{10}$ Smulders and de Feyter (2001) also find a significant negative effect of actual hours on preferred hours.
} 
working hours also differs per sector. Women working in retail predominantly want to work more, while women in education and business services most often want to work less. We also find differences with respect to several measures related to life and job satisfaction. ${ }^{11}$ In general, women who prefer to reduce working hours are more satisfied with the different aspects of their job. However, they are significantly less happy with the amount of leisure they have at their disposal. The women who reported that they worked their preferred number of hours are the happiest with the different attributes of their job.

\section{$2.3 \quad$ Regression analysis}

We next investigate the correlations between the preferred change in working hours and the background characteristics presented in Table 2.1, holding other factors constant. $^{12}$ We denote the difference between the hours a woman prefers to work $(h p)$ and the hours she actually works $(h)$ by $h m$, i.e. $h m=h p-h$. We perform a regression analysis which isolates the effects of the different background characteristics on the preferred change in working hours:

$$
h m_{i t}=\alpha_{0}+\boldsymbol{\alpha}^{\prime} \mathbf{x}_{\mathbf{i t}}+\epsilon_{i t}
$$

The column vector $\mathbf{x}_{\mathbf{i t}}$ contains individual characteristics and a constant term, whereas the coefficients in the row vector $\boldsymbol{\alpha}^{\prime}$ measure the effects of these characteristics on $h m$, keeping everything else constant. ${ }^{13}$ For age, the number of children and income- and satisfaction variables, we subtract the average in the base category from the individual value, which allows us to interpret the constant term as an estimate of the average value of $h \mathrm{~m}$ in the base category. The base category consists of women who have completed mbo (basic vocational training), who are working in health care or the welfare sector, who do not provide semi-skilled or unskilled manual labor, are cohabiting (married and unmarried), and whose family owns the house they live in. Results are reported in Table 2.2.

In column 1 of Table 2.2 we present the relationship between the background variables and the desired change in working hours, excluding income and satisfaction

\footnotetext{
${ }^{11}$ All satisfaction measures are reported on a zero-to-ten scale, where a zero corresponds to "not at all satisfied" and a ten to "fully satisfied".

${ }^{12}$ Several studies performed analyses that are related to the one presented here. Fouarge and Baaijens (2003) and Keuzenkamp et al. (2009) analyzed the determinants of preferred changes in labor supply. However, in the latter study the authors exclude women working in jobs consisting of more than 24 hours per week. Both Keuzenkamp et al. (2009) and Fouarge and Baaijens (2003) control for the actual working hours in their model, which makes comparison with our approach difficult. As we are interested in the background characteristics of women who prefer to work longer or shorter hours, we do not include actual working hours as an explanatory variable.

${ }^{13}$ In the model presented here we follow Booth and Van Ours (2013) and allow for an individual effect that is not correlated with the explanatory variables by estimating a random-effects model.
} 
variables to highlight the correlations between socio-demographic characteristics and the desire to change working hours. Income and satisfaction variables are potential channels through which the background characteristics could influence $\mathrm{hm}$ and we therefore exclude them for now.

Table 2.2: Regression results

\begin{tabular}{|c|c|c|c|}
\hline Dependent variable: & $\begin{array}{l}(1) \\
h m\end{array}$ & $\begin{array}{l}(2) \\
h m\end{array}$ & $\begin{array}{l}(3) \\
h m\end{array}$ \\
\hline \multicolumn{4}{|c|}{ Educational attainment } \\
\hline Academic higher education & $\begin{array}{c}-2.06^{* * *} \\
(0.56)\end{array}$ & $\begin{array}{c}-3.59^{* * *} \\
(0.56)\end{array}$ & $\begin{array}{c}-3.30 * * * \\
(0.54)\end{array}$ \\
\hline Higher professional education & $\begin{array}{c}-1.23^{* * *} \\
(0.31)\end{array}$ & $\begin{array}{c}-2.07^{* * *} \\
(0.33)\end{array}$ & $\begin{array}{c}-1.92^{* * *} \\
(0.34)\end{array}$ \\
\hline Senior general secondary- or pre-university education & $\begin{array}{c}-0.11 \\
(0.43)\end{array}$ & $\begin{array}{l}-0.47 \\
(0.45)\end{array}$ & $\begin{array}{c}-0.10 \\
(0.43)\end{array}$ \\
\hline Preparatory secondary vocational education & $\begin{array}{c}0.48 \\
(0.35)\end{array}$ & $\begin{array}{c}0.46 \\
(0.37)\end{array}$ & $\begin{array}{c}0.72^{* *} \\
(0.36)\end{array}$ \\
\hline Primary or no education & $\begin{array}{l}-0.95 \\
(0.86)\end{array}$ & $\begin{array}{l}-1.18 \\
(0.92)\end{array}$ & $\begin{array}{l}-0.08 \\
(0.95)\end{array}$ \\
\hline \multicolumn{4}{|l|}{ Demographics } \\
\hline Age & $\begin{array}{l}-0.01 \\
(0.01)\end{array}$ & $\begin{array}{c}-0.06^{* * *} \\
(0.01)\end{array}$ & $\begin{array}{c}-0.06^{* * *} \\
(0.01)\end{array}$ \\
\hline Number of children in the household & $\begin{array}{c}0.59 * * * \\
(0.11)\end{array}$ & $\begin{array}{c}0.67^{* * *} \\
(0.11)\end{array}$ & $\begin{array}{c}0.63^{* * *} \\
(0.11)\end{array}$ \\
\hline Single & $\begin{array}{l}-0.57 \\
(0.39)\end{array}$ & $\begin{array}{l}-1.36 \\
(0.84)\end{array}$ & $\begin{array}{l}-0.72 \\
(0.86)\end{array}$ \\
\hline \multicolumn{4}{|c|}{ Type of job and sector } \\
\hline Semi- or unskilled manual labor & $\begin{array}{c}2.53^{* * *} \\
(0.44)\end{array}$ & $\begin{array}{c}3.46^{* * *} \\
(0.48)\end{array}$ & $\begin{array}{c}2.59 * * * \\
(0.45)\end{array}$ \\
\hline Government services and public administration & $\begin{array}{l}-0.57 \\
(0.48)\end{array}$ & $\begin{array}{l}-0.64 \\
(0.49)\end{array}$ & $\begin{array}{l}-0.43 \\
(0.46)\end{array}$ \\
\hline Business services & $\begin{array}{c}-2.14^{* * *} \\
(0.50)\end{array}$ & $\begin{array}{c}-2.31^{* * *} \\
(0.50)\end{array}$ & $\begin{array}{c}-1.80^{* * *} \\
(0.49)\end{array}$ \\
\hline Financial services & $\begin{array}{c}-0.86^{* *} \\
(0.43)\end{array}$ & $\begin{array}{c}-1.15^{* *} \\
(0.48)\end{array}$ & $\begin{array}{l}-0.67 \\
(0.50)\end{array}$ \\
\hline Utilities production, distribution and/or trade & $\begin{array}{c}-2.70^{*} \\
(1.56)\end{array}$ & $\begin{array}{c}-3.20^{*} \\
(1.77)\end{array}$ & $\begin{array}{c}-3.24^{*} \\
(1.96)\end{array}$ \\
\hline Education & $\begin{array}{c}-2.75^{* * *} \\
(0.45)\end{array}$ & $\begin{array}{c}-2.02^{* * *} \\
(0.45)\end{array}$ & $\begin{array}{c}-1.62^{* * *} \\
(0.43)\end{array}$ \\
\hline Retail trade & $\begin{array}{l}-0.41 \\
(0.42)\end{array}$ & $\begin{array}{c}0.61 \\
(0.47)\end{array}$ & $\begin{array}{c}0.67 \\
(0.47)\end{array}$ \\
\hline Industrial production & $\begin{array}{c}-1.77^{* * *} \\
(0.56)\end{array}$ & $\begin{array}{c}-1.40^{* *} \\
(0.58)\end{array}$ & $\begin{array}{c}-1.29 * * \\
(0.61)\end{array}$ \\
\hline Construction & $\begin{array}{c}-2.02^{*} \\
(1.17)\end{array}$ & $\begin{array}{c}-2.50 * * \\
(1.12)\end{array}$ & $\begin{array}{c}-2.18^{* * *} \\
(0.81)\end{array}$ \\
\hline Catering & $\begin{array}{c}0.69 \\
(0.93)\end{array}$ & $\begin{array}{l}1.50^{*} \\
(0.88)\end{array}$ & $\begin{array}{l}1.45^{*} \\
(0.81)\end{array}$ \\
\hline Transport, storage and communication & $\begin{array}{c}-2.05^{* *} \\
(0.96)\end{array}$ & $\begin{array}{c}-1.68^{*} \\
(0.97)\end{array}$ & $\begin{array}{l}-1.16 \\
(0.98)\end{array}$ \\
\hline Environmental services, culture recreation & $\begin{array}{l}-1.00 \\
(0.97)\end{array}$ & $\begin{array}{c}-0.38 \\
(0.95)\end{array}$ & $\begin{array}{l}-0.96 \\
(0.88)\end{array}$ \\
\hline
\end{tabular}

Continued on next page 
2 Working longer or shorter hours: Heterogeneity among working women

Table 2.2: Regression results (continued from previous page)

\begin{tabular}{|c|c|c|c|}
\hline Dependent variable: & $\begin{array}{l}(1) \\
h m\end{array}$ & $\begin{array}{l}(2) \\
h m\end{array}$ & $\begin{array}{l}(3) \\
h m\end{array}$ \\
\hline Other sectors & $\begin{array}{l}-0.49 \\
(0.34)\end{array}$ & $\begin{array}{c}-0.07 \\
(0.37)\end{array}$ & $\begin{array}{l}-0.00 \\
(0.35)\end{array}$ \\
\hline \multicolumn{4}{|c|}{ Financial information } \\
\hline Not a homeowner & $\begin{array}{l}0.60^{*} \\
(0.35)\end{array}$ & $\begin{array}{c}1.29^{* * *} \\
(0.36)\end{array}$ & $\begin{array}{c}1.47^{* * *} \\
(0.36)\end{array}$ \\
\hline $\ln$ (Hourly wage) & & $\begin{array}{c}5.94^{* * *} \\
(0.62)\end{array}$ & $\begin{array}{c}6.51^{* * *} \\
(0.66)\end{array}$ \\
\hline $\ln ($ Other income $)$ & & $\begin{array}{l}-0.02 \\
(0.11)\end{array}$ & $\begin{array}{c}0.06 \\
(0.11)\end{array}$ \\
\hline \multicolumn{4}{|c|}{ Satisfaction with aspects of job } \\
\hline Wage & & & $\begin{array}{c}-0.24^{* * *} \\
(0.07)\end{array}$ \\
\hline Working hours & & & $\begin{array}{c}0.46^{* * *} \\
(0.08)\end{array}$ \\
\hline Type of job & & & $\begin{array}{c}-0.12 \\
(0.12)\end{array}$ \\
\hline Career & & & $\begin{array}{c}-0.39^{* * *} \\
(0.10)\end{array}$ \\
\hline Current job & & & $\begin{array}{c}0.15 \\
(0.12)\end{array}$ \\
\hline Atmosphere & & & $\begin{array}{c}0.02 \\
(0.08)\end{array}$ \\
\hline Amount of leisure & & & $\begin{array}{c}0.55^{* * *} \\
(0.06)\end{array}$ \\
\hline Constant & $\begin{array}{c}-0.80^{* * *} \\
(0.28)\end{array}$ & $\begin{array}{c}-0.84^{* * *} \\
(0.30)\end{array}$ & $\begin{array}{c}-1.15^{* * *} \\
(0.30)\end{array}$ \\
\hline Number of observations & 4,468 & 4,249 & 3,806 \\
\hline Number of individuals & 2,226 & 2,122 & 1,976 \\
\hline
\end{tabular}

Note: Results of a random-effects least squares estimation on the 2008-, 2009- and 2010-wave of the LISS data. Following Booth and Van Ours (2013) we report standard errors clustered at the individual level between parentheses. The asterisks ***, ** and * denote significance at the 1-, 5- and 10-percent level respectively. The base category consists of women who finished intermediate vocational education, are working in the sector health care and welfare, do not provide semi-skilled or unskilled manual labor, are cohabiting (married and unmarried) and their family is owner of the house they live in. In each year, interviews have been conducted in different months. To correct for potential effects the month of the interview might have on the preferred change in working hours, add include dummies as explanatory variables to control for this. The base category has been interviewed in April 2010 .

The significant negative estimate of the constant term $(-0.8$; p-value $<0.01)$ in column 1 indicates that women in the reference category on average want to work shorter hours than they currently do. Keeping everything else constant, we find that those who completed higher vocational $(-2.0$; p-value $<0.01)$ and university education $(-2.9 ;$ p-value $<0.01)$ would like to reduce their working hours even more. ${ }^{14}$ In general, highly educated women would like to work shorter hours. The differences between the reference category (intermediate vocational education) and the below average educated women is insignificant.

\footnotetext{
${ }^{14}$ Analogously one can calculate the average $h m$ of women with other characteristics, by adding the relevant coefficients.
} 
Women who have children living in the household would like to work significantly more. ${ }^{15}$ We also find that women who perform low- or unskilled labor, but whose other characteristics are similar to those of the base category, would like to increase working hours significantly by 1.7 hours per week on average ( $\mathrm{p}$-value $<0.01$ ). Women working in education and business services - two of the largest sectors would prefer to reduce working hours significantly by 3.6 and 2.9 on average (both p-values $<0.01)$. That is, they would like to reduce working hours more than women employed in health care and the welfare sector, who already would like to work shorter hours than they currently do.

In column 2 we include financial characteristics, the hourly wage and other household income, in the model. We find a positive correlation between the desired change in working hours and the log of the hourly wage. The coefficient implies that an individual with a wage that is 10 percent higher than the average wage in the base category (approximately 9.30 euros) reports a preferred increase in hours that is $5.94 \times \ln (1.1)=0.57$ hours higher than preferred hours in the base category. The significant effect of the wage rate suggests that it could be an important instrument for bringing preferred hours in line with actual hours, but the effect size implies that a large wage increase would be required to establish this. ${ }^{16}$

Most of the coefficients on educational and sectoral controls become stronger when including financial incentives. The larger coefficients suggest that the effects reported in column 1 are attenuated by an opposing force that is working through the wage rate. For example, highly educated women earn a higher wage, which is positively correlated with the desire to increase working hours. It seems that the higher hourly wage partly corrects for the discrepancy between actual and preferred hours.

When adding satisfaction variables in column 3, we find a pattern that resembles the pattern previously uncovered in Table 2.1. Greater satisfaction with one's career and wage rate is associated with a stronger desire to decrease working hours, whereas a high score on satisfaction with working hours and the amount of leisure are positively associated with $\mathrm{hm}$. The coefficient on the satisfaction with the amount of leisure time $(0.6$; p-value $<0.01)$ indicates that a one-point increase in

\footnotetext{
${ }^{15}$ In a slightly refined regression setup (Loog et al., 2011), we find that mainly single and cohabiting women without children or with one child would like to work significantly less than cohabiting women with two children (the base category).

${ }^{16}$ The average preferred change for women working 23 hours or more per week is about -3.8 hours. According to the parameter estimates in Table 2.2 it would require an increase in the wage rate of 90 percent $\left(\exp \left(\frac{3.8}{5.94}\right)=1.90\right)$ in order to remove this discrepancy. That is, if one would interpret the coefficient on the wage rate as a causal effect. Furthermore, a positive change in $\mathrm{hm}$ may also be the result of less demand, as a result of higher wages. This follows from the fact that actual hours $h$ likely depend on demanded hours $h d$ as well as preferred hours $h p$. If we simplify this relationship as the weighted average $h=\alpha h p+(1-\alpha) h d$ with $0<\alpha<1$, it can be shown that $\frac{\partial h m}{\partial w}=(1-\alpha)\left(\frac{\partial h p}{\partial w}-\frac{\partial h d}{\partial w}\right)$. A positive sign of $\frac{\partial h m}{\partial w}$ could then be the result of $\frac{\partial h d}{\partial w}<0$ as well as $\frac{\partial h p}{\partial w}>0$. Moreover, Dutch women do not seem to react strongly to an increase in the wage rate (Bosch and Van Der Klaauw, 2012; Evers et al., 2008).
} 
2 Working longer or shorter hours:

Heterogeneity among working women

the satisfaction-scale leads to a 0.6-hour increase in $\mathrm{hm}$.

The results indicate that the dissatisfaction with the amount of leisure time is expressed in the desire to decrease weekly working hours. Leisure is what is left after subtracting time spent working for pay and time for home production (e.g. running errands, child rearing, etc.) from the total endowment of time (Mincer, 1963). The importance of leisure time is reflected in the less negative coefficients on the independent variables and holds in particular for the highly educated, for singles (albeit insignificant) and for those working in business services, financial services and education. Apparently, the marginal utility of leisure is higher than the marginal utility they would indirectly (via salary or social contacts and the like) derive from an additional hour of work. Therefore, they would like to work less. Indeed, Portegijs et al. (2008) show that enjoying more leisure time is a major reason why Dutch women work in part-time jobs.

The strong negative coefficients for the highly educated and the significant positive coefficients for the below-average educated and semi- or unskilled manual workers suggest that there is currently relatively more demand for highly educated than for less educated workers. The fact that many women still work in 'small parttime jobs', the reason for founding the Task Force Part-time Plus, is therefore not entirely attributable to the fact that they do not want to work longer hours. It seems that, at the current wage rate, there is not enough demand for the types of labor supplied by particular subgroups of the female work force. This holds in particular for the less educated and for those performing semi- or unskilled manual work. ${ }^{17}$ This conjecture is confirmed by survey information presented by Keuzenkamp et al. (2009) who show that many women working in the cleaning sector would like to work longer hours in their current jobs, but are unable to do so.

Other characteristics also explain part of the variation in the desired change. In some of the larger sectors like business services, financial services and education, women have an even stronger tendency to want to reduce their weekly working hours than in the sector health care and welfare, where women would already prefer a sizable hours reduction. Age also plays a significant role. Especially older women would like to work less. On the other hand, the wage rate positively affects $\mathrm{hm}$. However, it is questionable to what extent the wage rate can make up for the discrepancies uncovered here (see footnote 16). Therefore, it seems important to think of other instruments that are likely to positively affect preferred working hours.

\footnotetext{
${ }^{17}$ Because we do not include a full set of interaction effects between all the characteristics of interest, it is theoretically possible that those performing semi- or unskilled manual labor are highly educated individuals who would like to work longer hours in a job at their own education level. However, the fraction of highly educated women in semi- or unskilled manual labor is negligible.
} 


\subsection{Policy}

The analysis in this chapter has identified two particular groups of working women: a group consisting of relatively high-wage workers who, on average, currently work longer hours and who would like to reduce working hours, and a second group of women with less than average education who work few hours and often perform semi- or unskilled manual labor. The latter group prefers to increase their weekly working hours. ${ }^{18}$

The heterogeneity described here indicates that a fraction of the female work force would like to work longer hours per week than they currently do, even though women would like to work shorter hours on average. This finding suggests that increasing participation on the intensive margin across the board is not only a matter of stimulating labor supply, but also one of stimulating the demand for certain tasks. Moreover, solely stimulating the supply side would not yield higher hours worked for all women, as several workers already prefer to work longer hours under current conditions. This concerns mainly lower educated women, or women who are performing semi- or low skilled manual labor. ${ }^{19}$

One example of a policy intervention that would take into account the discrepancies shown in this study could be to stimulate the market for household services. Such services could be provided by those who are currently supplying unskilled labor, and are willing to work longer hours. Stimulating the purchase of homeproduction services ${ }^{20}$ may increase participation along the intensive margin of those who would like to work longer hours already (semi- and unskilled manual workers and those with a below-average educational attainment), while it might reduce the discrepancy between actual and preferred hours of the highly educated women who prefer to work shorter hours. Whether buying household services can decrease the discrepancy between actual and preferred hours should be examined in future research. The potential success depends on a number of factors which will be briefly discussed in turn. First, we should get a clear overview of the tasks that women who want to work shorter hours, i.e. who would like to enjoy more leisure, would prefer not to do themselves. ${ }^{21}$ The extent to which women appreciate certain tasks

\footnotetext{
${ }^{18}$ About seven percent of the sample in the 2010-wave consists of women who are performing semi- or unskilled manual labor and women who finished intermediate secondary (or lower) education who would like to increase weekly working hours. The desired increase in working hours is about seven.

${ }^{19}$ The motivation behind writing this chapter was the ongoing debate of increasing female labor force participation along the intensive margin. We therefore do not discuss whether it is economically desirable to artificially increase the demand for products or services. Moreover, we are aware of the fact that we perform a partial-equilibrium analysis. That is, we do not fully account for the demand side of the market. Assuming actual hours are generated as described in footnote 16 , we at least partially account for the demand side.

${ }^{20}$ Tijdens (2000) discusses several services to enhance employee comfort, so-called "gemaksdiensten".

${ }^{21}$ Portegijs et al. (2008) discuss conditions under which women who already indicate to be willing
} 
2 Working longer or shorter hours:

Heterogeneity among working women

or activities has been the subject of international research (Kahneman et al., 2004; Krueger et al., 2009), but such research has to the best of our knowledge not yet been carried out among Dutch women (who want to work fewer hours).

Second, it has to be examined whether women who would like to work longer hours, and in particular those who are currently in semi- or unskilled manual jobs, are willing to perform the type of services referred to above. The fact that a large proportion of women in the cleaning sector wants to work longer hours in their current job (Keuzenkamp et al., 2009) suggests that they might also want to do so in a comparable job.

Third, the (latent) demand for personal or household services needs to be activated, either directly via households or indirectly via employers. Buying personal services does not yet seem ingrained in our culture and cultural change may be a necessary condition for the aforementioned idea to be successful. It should become socially accepted to buy low- or unskilled services that someone prefers not to perform themselves. The high untapped potential at the lower end of the labor market, and the desire for more leisure time at the top of the market, suggests that this is not yet the case. This conjecture seems to be confirmed by information from the Labor Accounts (Arbeidsrekeningen) of Statistics Netherlands. The number of working hours by "persons employed by private households" increased by only 4.8 percent between 1990 and 2010, from 125 to 131 million hours (CBS StatLine). In the same period, the number of double-income families of which at least one partner works full time increased by 58.3 percent (Statistics Netherlands, 2011).

The aforementioned questions cannot be analyzed using our data. However, given the amount of attention paid to studies that have 'increasing participation' as a starting point, it seems in general interesting to develop policies aimed at the group of women that wants to work longer hours already, which will increase hours worked at the lower end of the labor market. This might then reduce the discrepancy between preferred working time at the higher end of the labor market, which is by itself desirable (Wooden et al., 2009).

\subsection{Conclusion}

In this chapter we presented evidence for heterogeneity with respect to the discrepancy between actual and preferred working hours per week. Based on the analysis we can conclude that increasing participation in terms of working hours across the board is not just a matter of stimulating supply. Several women would already like to increase working hours under current circumstances.

The analysis shows that women who perform semi- or unskilled manual labor,

to work longer hours will do so. For our study especially women who want to work shorter hours - those disregarded by the study mentioned here - are of key importance. 
mainly the lower educated, would like to work longer hours than they currently do. On the other hand, especially highly educated women, usually working relatively long hours on average, want to work shorter hours.

The particular nature of the heterogeneity with respect to the discrepancy between actual and preferred hours suggests that policy could be aimed at promoting substitution of household production for leisure time, that is, higher educated women who want to work shorter hours should be stimulated to purchase personal services on the market, where such services are produced by women in lowand unskilled manual jobs who would like to work longer hours. This form of substitution could create a more efficient allocation on the labor market. We show, using data on preferred working hours, that the promotion of outsourcing of household production may be effective in this respect. Moreover, such a policy might increase average participation along the intensive margin.

One important caveat pertains to the implicit assumption made in this chapter, which is that women prefer (or are indifferent to) time devoted to market work over housework. This assumption may not hold for all women. In that case, the abovementioned policy recommendation does not have an effect on all working women. Future research should investigate how Dutch working women value market work compared to household production. 


\section{The scope for increasing total hours worked $^{1}$}

\subsection{Introduction}

Policymakers in the Netherlands are concerned about the consequences of the aging society as aging leads to a smaller potential workforce and tax base, threatening the sustainability of the welfare state. To mitigate the problem of the shrinking working population, policymakers would welcome an increase in total hours worked. Such an increase could result from an increase in the participation rate (extensive margin) or an increase in the number of working hours by individuals already working (intensive margin).

At the extensive margin there seems to be little scope for increasing total hours: Relative to the European Union as a whole, Dutch men and women more often work in paid jobs (Statistics Netherlands, 2009) and the growth in the female participation rate is likely to decrease in the near future (Euwals et al., 2011). However, the intensive margin does offer scope to increase total hours, particularly among the large share of working women in the Netherlands who work part-time. ${ }^{2,3}$

\footnotetext{
${ }^{1}$ This chapter is based on joint work with Thomas Dohmen and Maarten Vendrik, and is published in De Economist (Loog et al., 2013). We thank Didier Fouarge, participants at the Nederlandse ArbeidsmarktDag (The Hague, 2011) as well as an anonymous referee for comments on an earlier draft of this paper.

${ }^{2}$ This possible route of increasing the tax base has been acknowledged by policymakers and led to the creation of the Task Force Part-time Plus in 2008 (Task Force Part-time Plus, 2008, 2010) to address this issue (Ministry of Social Affairs, 2008).

${ }^{3}$ The strong and prevalent preference among women for part-time jobs is well documented in the literature (e.g., Booth and Van Ours, 2013; Portegijs et al., 2008).
} 
The analysis in the previous chapter reveals that working women differ with respect to their preferences for work and leisure. When considering policies aimed at increasing the total number of working hours by women, it seems apparent that policies for women who prefer to work longer hours need a different focus than policies for those who prefer to work less. Consider, for example, a supplystimulating policy. If applied, policy should primarily be focused on the latter group for at least two reasons. First, the fact that employers like this group to work longer hours than they prefer to work suggests excess demand for such women. This is not the case for those who already prefer to work longer hours. Rather, in order to increase hours worked in the latter group, one may consider policies stimulating the demand side of the market. ${ }^{4}$ Second, aligning preferred and actual working hours seems to be welfare-enhancing (Wooden et al., 2009) and at the same time may also have positive long-term effects on female labor supply, since women who would like to work (substantially) shorter hours have a stronger tendency to leave the workforce altogether (Euwals, 2001).

To examine how the desire to work shorter or longer hours varies among and within segments of the labor market, we extend the concept of "equilibrium hours of work" (denoted $h_{0}$ ), as introduced in Booth and Van Ours (2013), who estimate two linear probability models relating preferences for working longer and shorter hours to actual working time. The authors find that the probability of preferring to work longer hours decreases with the number of hours worked, whereas the probability of preferring to work shorter hours increases with the number of working hours. The authors estimate that the two probabilities are equal at about 22 hours per week and denote this as the equilibrium hours of work. ${ }^{5}$

Our approach consists of two parts. In the first part of the analysis we calculate the number of hours beyond which there is a tendency to prefer a decrease in hours on average. We allow this point to vary with group-specific characteristics such as age and educational attainment. The second part of the analysis investigates what proportion of each type/group works longer hours than its equilibrium value. This fraction is an indication of how many women with a particular set of characteristics we expect to be willing to work shorter hours. A high fraction for a certain group would indicate, for example, that a supply-stimulating policy may be fruitful to increase working hours within this group.

In the next section we describe the data used in the analysis. Section 3.3 elaborates on the discrepancy between actual and preferred working hours, and the interpretation of the concept of equilibrium hours of work. Section 3.4 discusses the estimation of this equilibrium. Section 3.5 presents the analysis. Section 3.6 discusses the study's relevance for policy and concludes.

\footnotetext{
${ }^{4}$ See the previous chapter of this dissertation.

${ }^{5}$ In the context of Booth and Van Ours (2013) the notion of equilibrium means that, on average, individuals do not prefer to work longer or shorter hours. It does not imply that no individual would like to change hours.
} 


\subsection{Data}

The data used in the first part of the analysis are drawn from the 'Work and Schooling' survey of the Longitudinal Internet Studies for the Social sciences (LISS). The LISS is a representative, probability-based internet panel (Scherpenzeel, 2011) which provides us with detailed socioeconomic, demographic, and labor supply information. ${ }^{6}$ We restrict the sample to working women aged between 16 and 59 (inclusive) who worked in 2008, 2009, and/or 2010. Students, self-employed workers, and recipients of disability benefits are excluded from the sample. We also exclude women who work or prefer to work more than 84 hours a week.

The variables of interest are the actual and preferred number of weekly working hours ( $h$ and $h p$, respectively). The wording of the question regarding the actual hours is as follows: "How many hours per week do you actually on average work in your job? If you have multiple jobs, please consider the job most important to you. Whether or not extra hours are paid is irrelevant." A similar question asks for the number of hours worked in a second job. For women with more than one job, about six percent of the female respondents in 2010, the answers to these two questions are added to construct actual hours, $h$. The wording of the question regarding the preferred number of hours $(h p)$ is as follows: "How many hours per week in total would you like to work? This concerns the amount of hours worked in all of your jobs combined." 7 We assume that this question is answered with respect to their current job(s) and current conditions of employment and circumstances, not under the assumption of "ideal circumstances" (e.g. being able to arrange child care). ${ }^{8}$ In addition, we assume that the partner's labor supply and income are perceived as exogenous by the subject. ${ }^{9}$ Combining information on the preferred labor supply with the total number of hours worked in all jobs, we construct a measure for the desired change in hours worked $(h m=h p-h)$. This measure is positive for those who want to work longer hours per week, negative for those who desire to work shorter hours, and zero for those who do not want to change the number of hours

\footnotetext{
${ }^{6}$ The LISS panel is administered by CentERdata (Tilburg University).

${ }^{7}$ The wording (in Dutch) of the questions concerning average actual and preferred hours is as follows: "Hoeveel uur per week werkt u gemiddeld in werkelijkheid in uw baan? Hebt u meerdere banen, neem dan de voor u belangrijkste baan. Of overuren al dan niet betaald worden doet niet terzake"; "Hoeveel uren per week zou u in totaal willen werken? Het gaat om het aantal uren in alle banen die u hebt, bij elkaar genomen."

${ }^{8}$ Even though the question specifically asks for "your job(s)," some may want to work longer hours in another job. However, only six percent of the individuals in our sample stated they would prefer "other or more work." Unfortunately, it is impossible to distinguish between "other" and "more." In any case, it seems plausible that the vast majority interpreted the question according to our assumption.

${ }^{9}$ This is one of the features of the "male chauvinist model" (Killingsworth, 1983, p. 30). The motivation behind stimulating female labor supply is increasing tax revenues. Indeed, this would only work if men (particularly the husbands of those women who start working longer hours) would not decrease their hours worked in reaction to the increase in female participation. We therefore view the partner's labor supply (and therefore any other income in the household) as exogenous.
} 
they work.

In the second part of the analysis we employ data from the 2008 Dutch Labor Force Survey (Enquête Beroepsbevolking, henceforth LFS) to investigate the share of individuals within a certain group working longer or shorter hours than the $h_{0}$ belonging to that group. The LFS is representative for the Dutch labor force. We used data on educational attainment, the sector in which someone works, the individual's age, whether children are living in the household and the number of actual weekly working hours.

\subsection{Discrepancy between actual and preferred hours}

The summary statistics presented in Table 3.1 and Figure 3.1 reflect the high degree of heterogeneity in the length of the typical workweek of Dutch women. The data also show the part-time nature of female employment. Dutch working women prefer a workweek of about 26 hours on average, according to our measure of preferred hours. ${ }^{10}$

In many applications, labor economists (implicitly) assume $h p=h$ (Kahn and Lang, 1991), a simplification that originates from the assumption that workers "can freely choose employers offering different wage and hours packages" (Blundell and MaCurdy, 1999, p. 1588). Table 3.1 shows that this assumption is in stark contrast to the situation in the Netherlands. ${ }^{11}$ On average, Dutch women would like to work significantly less than they currently do ( $p$-value $<0.01)$. Preferred hours equal actual hours for only 38 percent of the sample in 2010, whereas 44 percent would like to decrease weekly hours. The remaining 18 percent would like to work longer hours.

\footnotetext{
${ }^{10}$ Euwals et al. (1998) show that, in addition to qualitative information, using preferred hours helps predict actual future hours.

${ }^{11}$ Differences between actual and preferred hours have been documented before (e.g., Keuzenkamp et al., 2009; Stewart and Swaffield, 1997) and can be explained theoretically (see footnote 4 in the previous chapter).
} 
3 The scope for increasing total hours worked

Table 3.1: Summary statistics

\begin{tabular}{|c|c|c|c|c|}
\hline Variables: & Mean & S.d. & Min. & Max. \\
\hline \multicolumn{5}{|l|}{ Hours } \\
\hline Actual hours $(h)$ & 28.7 & 10.5 & 2 & 70 \\
\hline Preferred hours $(h p)$ & 26.6 & 8.8 & 0 & 55 \\
\hline Preferred change in hours $(\mathrm{hm})$ & -2.1 & 7.1 & -46 & 32 \\
\hline \multicolumn{5}{|c|}{ Demographics } \\
\hline Age & 41.9 & 10.3 & 18 & 59 \\
\hline Number of children in household & 1.1 & 1.1 & 0 & 6 \\
\hline Cohabiting, children in the household & $49 \%$ & & 0 & 1 \\
\hline Cohabiting, no children in the household & $29 \%$ & & 0 & 1 \\
\hline Married & $58 \%$ & & 0 & 1 \\
\hline \multicolumn{5}{|c|}{ Education } \\
\hline Academic higher education (wo) & $9 \%$ & & 0 & 1 \\
\hline Professional higher education (hbo) & $28 \%$ & & 0 & 1 \\
\hline Basic vocational training (mbo) & $31 \%$ & & 0 & 1 \\
\hline \multicolumn{5}{|l|}{ Income } \\
\hline Net hourly wage & 11.4 & 5.4 & 1.7 & 86.6 \\
\hline Other income in the household & 1,709 & 1,249 & 0 & 11,000 \\
\hline
\end{tabular}

Note: Summary statistics based on survey responses in the 2010-wave of the LISS panel $(\mathrm{N}=1,443)$. Information on actual hours $(h)$ comes from the survey question "How many hours per week do you actually on average work in your job? If you have multiple jobs, please consider the job most important to you. Whether or not extra hours are paid is irrelevant." This question is combined with information on the number of hours in a potential additional job. Information on preferred hours $(h p)$ comes from the survey question "How many hours per week in total would you like to work? This concerns the amount of hours worked in all of your jobs combined." The desired change in hours is the difference between actual and preferred hours $(h p-h)$. The net hourly wage is approximated by the personal net income per month, divided by the average number of hours actually worked per month (i.e., weekly actual hours times $4 \frac{1}{3}$ ).

Figure 3.2 illustrates the relation between actual and preferred working hours. It plots the average value of $h p$ conditional on $h$, as well as a 45-degree line on which actual hours equal preferred. The intersection of the two lines, denoted by $h_{0}$, provides information about the tensions between the preferred hours, on the one hand, and actual and demanded hours, on the other hand. To the left of this point (i.e., $h<h_{0}$ ) women on average prefer to work longer hours, whereas women to the right of this point (i.e., $h>h_{0}$ ) prefer to work fewer hours on average. Consequently, the value of $h_{0}$ provides us with two insights. First, the parameter offers us the ranges of hours in which policies should take a different focus; to the left of this point policy should be aimed at individuals who want to work longer hours. To the right of this point policy should be tailored toward those who would like to reduce their working hours. Second, evaluation of the relative sizes of the groups to the left and right of this point yields insights into the scope for policy when a particular group is targeted. Again, consider the example of a supply-stimulating policy: The larger the fraction of a group that works hours longer than $h_{0}$, the larger the scope for policymakers to align preferred hours and actual hours worked through a supply-stimulating policy, and the larger the scope to eventually increase hours worked. ${ }^{12}$

\footnotetext{
${ }^{12}$ If the inequality $h>h_{0}$ holds for relatively many women of a certain type, it indicates that employers like these women to work longer hours and it may be beneficial to stimulate the supply
} 


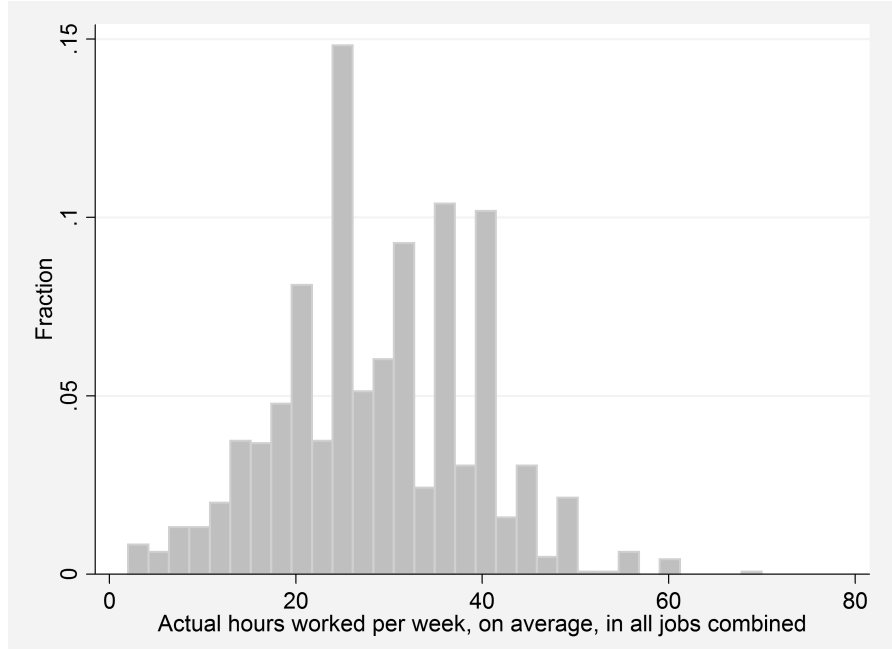

Figure 3.1: Actual weekly working hours

Note: The distribution of average weekly total working hours $(h)$ by working women in the Netherlands (Source: LISS, 2010).

Figure 3.3 illustrates the heterogeneity in $h_{0}$ documented in the first part of the analysis. It shows that the point where preferred and actual hours are equal depends on individual characteristics. The dashed line represents the preferences of nonmanual workers aged 55-59, conditional on the number of weekly working hours. The solid line represents the same for semi- or unskilled manual workers aged 1635. The latter group prefers to decrease their hours worked (on average) when they work about four days per week or more. The former group's tendency to desire a decrease in hours sets in earlier, at about two days per week.

\subsection{Estimation}

Figures 3.2 and 3.3 suggest that the relationship between actual and preferred hours (and thus the desired change, $h m$ ) is nonlinear. The nonlinearity in $h m=f(h)$ is approximated by a third-order polynomial of the form

$$
h m_{i t}=\gamma_{1}\left(h_{i t}-h_{0}\right)+\gamma_{2}\left(h_{i t}-h_{0}\right)^{2}+\gamma_{3}\left(h_{i t}-h_{0}\right)^{3}+\epsilon_{i t},
$$

where $\gamma_{1,2,3}$ and $h_{0}$ are parameters to be estimated by nonlinear least squares. ${ }^{13}$

of labor within this group. This holds under the assumption that the actual number of hours worked is a function of demanded hours as well as preferred hours: $h=\alpha h d+(1-\alpha) h p$, where $0<\alpha<1$. This implies that if $h p<h, h d>h$.

${ }^{13}$ The Taylor approximation of $f(h)$ at $h=h_{0}$ equals $f\left(h_{0}\right)+\frac{f^{\prime}\left(h_{0}\right)}{1 !}\left(h-h_{0}\right)+\frac{f^{\prime \prime}\left(h_{0}\right)}{2 !}\left(h-h_{0}\right)^{2}+$ 


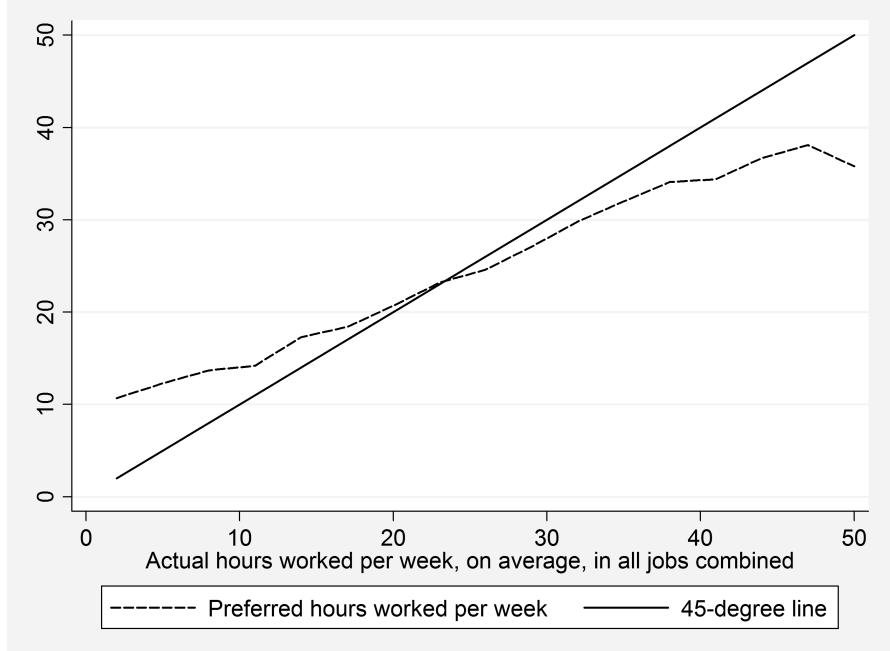

Figure 3.2: Equilibrium hours of work

Note: The average number of preferred working hours $(h p)$ conditional on actual working hours, in three-hour categories (Source: LISS, 2010).

The estimate of $h_{0}$ approximates the point where actual and preferred hours are equal.

The functional form of equation 3.1 offers a neat possibility to investigate how $h_{0}$ depends on individual characteristics. As an example, consider a dichotomous variable $U_{i t}$ representing whether individual $i$ holds a university degree $\left(U_{i t}=1\right)$ or not $\left(U_{i t}=0\right)$ and include it in the estimation as follows (dropping subscripts): $h m=\gamma_{1}\left(h-h_{0}-\beta U\right)+\gamma_{2}\left(h-h_{0}-\beta U\right)^{2}+\gamma_{3}\left(h-h_{0}-\beta U\right)^{3}+\epsilon$. In this case the estimate of $h_{0}$ represents the crossing point (in terms of Figure 3.2) for the base category of no university degree $(U=0)$, whereas the sum of $h_{0}$ and $\beta$ estimates the equilibrium hours of work for women with a university degree $(U=1)$. Other characteristics of interest can be included in the analysis analogously.

Since the model has to be solved by an iterative process and since it can have multiple solutions, the starting values for the process must be provided. We first estimate $h_{0}$ without controls and follow Booth and Van Ours (2013) by choosing 22 as the starting value. In the next step we add one control variable and plug in the estimate for $h_{0}$ found in the previous step. The starting value for the control variable is then set to zero, after which the model is solved for the second time and, along with the new estimate of $h_{0}$, yields an estimate of the coefficient of the control variable. This process is repeated until all controls are added.

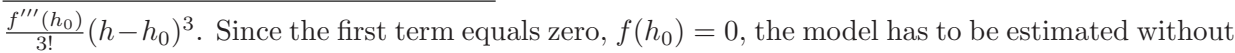
a constant term. Alternatively, we could have chosen to estimate a third-order polynomial in $h$ and solve for $h_{0}$ by equating this estimated polynomial to zero. However, our approach immediately provides us with the estimate of $h_{0}$ as well as its standard error. 


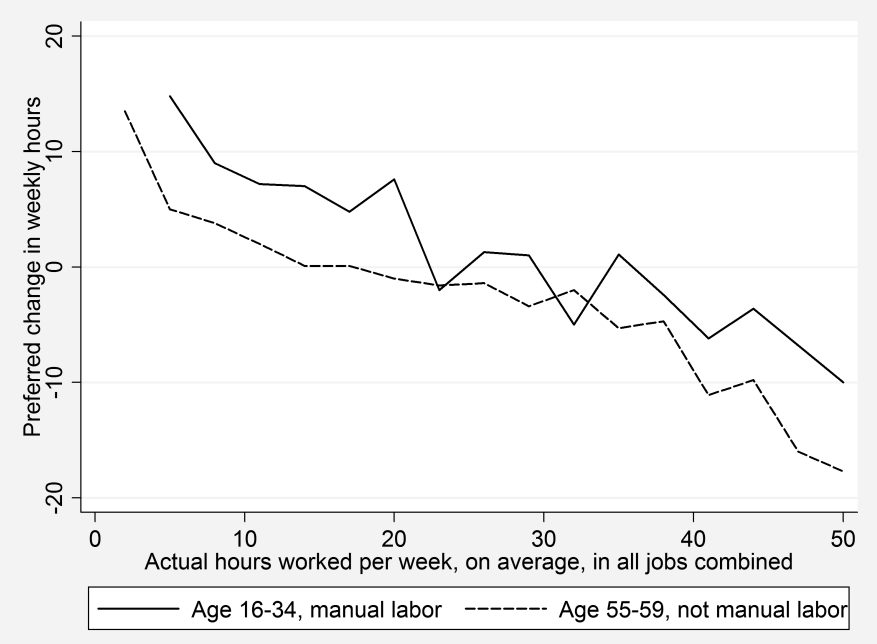

Figure 3.3: Heterogeneity in the "equilibrium hours of work"

Note: The average of preferred hours $(h p)$ given actual hours (in three-hour categories), conditional on background characteristics (Source: LISS, 2010).

\subsection{Results}

\subsubsection{Heterogeneity between segments}

Table 3.2 presents the results of the estimation of model 3.1, augmented with proxies for human capital. The reported $h_{0}$ represents the hours equilibrium for the base category. The base category consists of women who: completed their basic vocational training (mbo); work in health care and welfare; do not provide semi-skilled or unskilled manual labor; are aged between 35 and 44; cohabit, have children living in the household; (co-)own their family home; earn a net hourly wage between 14 and 25 euros; and have an additional household income between 1,000 and 2,000 euros a month. Women with these characteristics form the largest group in the Labor Force Survey (LFS).

The hours equilibrium of the base category $\left(h_{0}\right)$ equals 20.7. ${ }^{14}$ To illustrate the impact of background characteristics on this estimate, we compare it with the hours equilibrium of 25-34 year old university graduates working in the public sector. Adding the relevant coefficients for the latter yields an estimate of 25.9 (s.e. $=1.6$ ), indicating that the desire to work less sets in at about 26 hours per week. This

\footnotetext{
${ }^{14}$ The results from model 3.1 are in line with the work of Booth and Van Ours (2013). When restricting the sample according to their study (non-single women in their prime), we find that $\hat{h}_{0}=21.6$, which is comparable to the 21.7 hours reported by Booth and Van Ours (2013). So, a different method, a different sample, and quantitative instead of qualitative data yield similar results.
} 
point lies significantly above the same estimate for the base category ( $p$-value $<$ 0.01). For other background characteristic types of women the coefficients can be combined in similar ways.

In general, we find that the hours equilibrium depends on educational attainment and that there is considerable heterogeneity between sectors. Yet, the association between age and $h_{0}$ is strongest. Women aged 55-59 have a value of $h_{0}$ that is 4.5 hours less than that of the base category (women aged 35-44). In contrast, for women in the youngest age category, the estimate of $h_{0}$ is about 10 hours higher than for the base category.

In column 2 we allow for financial characteristics to affect $h_{0}$. We find that women in the highest wage category, constituting about 1.5 percent of the sample, have a significantly higher estimated value of $h_{0}$. This coefficient may reflect individual characteristics, such as preferences for work, that are correlated with high wages. We find that the coefficients for the age category remain stable, while the schooling coefficients undergo some changes. For example, the positive effect of holding a university degree on the value of $h_{0}$ we found earlier is partially due to the higher wages university graduates earned compared to women who only finished basic vocational training.

Table 3.2: Regression results

\begin{tabular}{|c|c|c|}
\hline Dependent variable: & $\begin{array}{l}(1) \\
h m\end{array}$ & $\begin{array}{l}(2) \\
h m\end{array}$ \\
\hline \multicolumn{3}{|l|}{ "Equilibrium hours of work" } \\
\hline$x^{2}$ & $\begin{array}{c}20.71^{* * *} \\
(0.80)\end{array}$ & $\begin{array}{c}21.58^{* * *} \\
(1.10)\end{array}$ \\
\hline \multicolumn{3}{|l|}{ Education } \\
\hline Academic higher education & $\begin{array}{l}1.85^{*} \\
(1.01)\end{array}$ & $\begin{array}{c}1.12 \\
(1.07)\end{array}$ \\
\hline Higher professional education & $\begin{array}{c}0.22 \\
(0.67)\end{array}$ & $\begin{array}{l}-0.05 \\
(0.70)\end{array}$ \\
\hline Senior general secondary- or pre-university education & $\begin{array}{c}0.27 \\
(1.02)\end{array}$ & $\begin{array}{c}0.02 \\
(1.07)\end{array}$ \\
\hline Preparatory secondary vocational education & $\begin{array}{l}-1.32 \\
(0.81)\end{array}$ & $\begin{array}{c}-1.68^{*} \\
(0.88)\end{array}$ \\
\hline Other education & $\begin{array}{c}0.50 \\
(1.76)\end{array}$ & $\begin{array}{c}0.48 \\
(1.87)\end{array}$ \\
\hline Primary or no education & $\begin{array}{l}-1.70 \\
(1.78)\end{array}$ & $\begin{array}{l}-2.77 \\
(1.96)\end{array}$ \\
\hline $\begin{array}{l}\text { Sector and type of work } \\
\text { Government services, public administration }\end{array}$ & $\begin{array}{l}2.21^{*} \\
(1.19)\end{array}$ & $\begin{array}{c}1.86 \\
(1.31)\end{array}$ \\
\hline Financial services & $\begin{array}{c}1.37 \\
(1.15)\end{array}$ & $\begin{array}{c}1.47 \\
(1.19)\end{array}$ \\
\hline Business services & $\begin{array}{l}-0.95 \\
(0.97)\end{array}$ & $\begin{array}{l}-0.66 \\
(1.01)\end{array}$ \\
\hline Education & $\begin{array}{c}-1.78^{* *} \\
(0.87)\end{array}$ & $\begin{array}{r}-1.80^{*} \\
(0.94)\end{array}$ \\
\hline
\end{tabular}

Continued on next page 
Table 3.2: Regression results (continued from previous page)

\begin{tabular}{|c|c|c|}
\hline & $(1)$ & $(2)$ \\
\hline Dependent variable: & $h m$ & $h m$ \\
\hline Retail trade & $\begin{array}{c}2.45^{* * *} \\
(0.93)\end{array}$ & $\begin{array}{c}2.65^{* * *} \\
(1.02)\end{array}$ \\
\hline Industrial production & $\begin{array}{c}1.82 \\
(1.40)\end{array}$ & $\begin{array}{c}1.87 \\
(1.51)\end{array}$ \\
\hline Construction & $\begin{array}{c}0.39 \\
(2.43)\end{array}$ & $\begin{array}{c}0.30 \\
(2.59)\end{array}$ \\
\hline Catering & $\begin{array}{c}4.44^{* *} \\
(1.79)\end{array}$ & $\begin{array}{l}4.32^{* *} \\
(1.80)\end{array}$ \\
\hline Transport, storage and communication & $\begin{array}{c}0.79 \\
(1.56)\end{array}$ & $\begin{array}{c}0.73 \\
(1.58)\end{array}$ \\
\hline Environmental services, culture, recreation & $\begin{array}{l}-1.27 \\
(1.59)\end{array}$ & $\begin{array}{l}-1.74 \\
(1.64)\end{array}$ \\
\hline Utilities & $\begin{array}{c}2.04 \\
(3.25)\end{array}$ & $\begin{array}{c}1.09 \\
(3.79)\end{array}$ \\
\hline Other sectors & $\begin{array}{l}1.18 \\
(0.79)\end{array}$ & $\begin{array}{l}1.23 \\
(0.84)\end{array}$ \\
\hline Manual work (semi- or unskilled) & $\begin{array}{l}1.80^{*} \\
(1.02)\end{array}$ & $\begin{array}{l}2.10^{*} \\
(1.11)\end{array}$ \\
\hline \multicolumn{3}{|c|}{ Demographics and household composition } \\
\hline Age 16-24 & $\begin{array}{c}10.23^{* * *} \\
(1.62)\end{array}$ & $\begin{array}{c}9.74^{* * *} \\
(1.74)\end{array}$ \\
\hline Age 25-34 & $\begin{array}{c}1.15 \\
(0.70)\end{array}$ & $\begin{array}{c}0.93 \\
(0.75)\end{array}$ \\
\hline Age 45-54 & $\begin{array}{l}-0.20 \\
(0.66)\end{array}$ & $\begin{array}{l}-0.55 \\
(0.72)\end{array}$ \\
\hline Age 55-59 & $\begin{array}{c}-4.47^{* * *} \\
(1.00)\end{array}$ & $\begin{array}{c}-4.65^{* * *} \\
(1.11)\end{array}$ \\
\hline No children in the household & $\begin{array}{c}3.00^{* * *} \\
(0.58)\end{array}$ & $\begin{array}{c}2.75^{* * *} \\
(0.65)\end{array}$ \\
\hline Single & $\begin{array}{l}1.69^{* *} \\
(0.71)\end{array}$ & $\begin{array}{c}0.97 \\
(1.36)\end{array}$ \\
\hline \multicolumn{3}{|l|}{ Financial characteristics } \\
\hline Not homeowner & & $\begin{array}{c}1.84^{* *} \\
(0.78)\end{array}$ \\
\hline Wage rate (euros): up to 10 & & $\begin{array}{l}-0.77 \\
(1.01)\end{array}$ \\
\hline Wage rate (euros): from 10 up to 14 & & $\begin{array}{l}-0.28 \\
(0.81)\end{array}$ \\
\hline Wage rate (euros): 25 and above & & $\begin{array}{l}6.79^{* *} \\
(2.75)\end{array}$ \\
\hline Other income (euros): up to 1,000 & & $\begin{array}{l}-0.13 \\
(1.31)\end{array}$ \\
\hline Other income (euros): from 2,000 up to 3,000 & & $\begin{array}{l}-0.92 \\
(0.64)\end{array}$ \\
\hline Other income (euros): 3,000 and above & & $\begin{array}{c}0.62 \\
(0.83)\end{array}$ \\
\hline \multicolumn{3}{|l|}{ Other (control) variables } \\
\hline$\gamma_{1}$ & $\begin{array}{c}-0.32 * * * \\
(0.02)\end{array}$ & $\begin{array}{c}-0.31^{* * * *} \\
(0.02)\end{array}$ \\
\hline
\end{tabular}

Continued on next page 
3 The scope for increasing total hours worked

Table 3.2: Regression results (continued from previous page)

\begin{tabular}{lcc}
\hline & $(1)$ & $(2)$ \\
Dependent variable: & $h m$ & $h m$ \\
\hline$\gamma_{2} \times 100$ & 0.12 & -0.04 \\
& $(0.16)$ & $(0.14)$ \\
$\gamma_{3} \times 100$ & $-0.02^{* * *}$ & $-0.02^{* * *}$ \\
& $(0.01)$ & $(0.01)$ \\
\hline Adjusted R-squared & 0.44 & 0.44 \\
Number of observations & 4,468 & 4,249 \\
Number of individuals & 2,226 & 2,122 \\
\hline
\end{tabular}

Note: Results of a non-linear least-squared estimation of model 3.1 on 2008-2010 LISS data. Following Booth and Van Ours (2013), we present cluster-robust standard errors between parentheses. The superscripts ***, **, and $*$ indicate significance of the coefficients at the 1,5 , and 10 percent levels, respectively. The base category is defined as follows: education, secondary vocational education; sector of employment, health and welfare; type of job, no manual work; age, 45-54 years old; household composition, cohabiting with children living in the household; homeownership, homeowner; wages, from 14 to 25 euros; other income, from 1,000 to 2,000 euros; month, April 2010. The month dummies are all insignificant and are not reported.

\subsubsection{Heterogeneity within segments}

The analysis presented above shows that the number of hours worked at which women do not want to work longer or shorter hours $\left(h_{0}\right)$ varies with background characteristics. This section investigates the fraction of women of a particular type who work longer hours than that type/group's value of $h_{0}$. Because this section analyzes data from subgroups, a large sample is needed. We therefore work with the LFS in this part of the analysis. ${ }^{15}$ A drawback of the LFS is that it does not provide income information. However, the results from the estimates presented in Table 3.2 indicate that, controlling for educational attainment and other characteristics, other income in the household hardly affects the value of $h_{0}$.

Table 3.3 presents summary statistics of a selection of sizeable groups from the LFS. Instead of providing a full-blown analysis of all possible combinations of the coefficients in column 1 of Table 3.2, we discuss a few types of workers that are common in the LFS. We identify a separate $h_{0}$ for the two largest educational groups and sectors. In addition, we compare a relatively old to a relatively young age category and distinguish between women with and without children. Table 3.3 presents summary statistics of only cohabiting women who do not perform semi- or unskilled manual labor.

The first four columns of Table 3.3 present background characteristics. As an example, consider the second row of the table. It displays information of working women who hold a higher vocational degree (hbo) and work in business services, are between 25-34 years of age and live in a household without non-adult children. The absolute number of respondents in the LFS, not calibrated to population totals,

\footnotetext{
${ }^{15}$ The available information in the LFS concerning preferred working hours is not suited for the first part of our analysis.
} 
is presented in column 5. Column 6 shows that the average woman with this particular set of characteristics works 37.5 hours per week. Since we do not have the appropriate information on preferred hours in the LFS (see footnote 15), column 7 presents the point estimates of the desired change in hours worked $(h p-h)$ from a random-effects regression on LISS data (Table 3.4). From these results we calculate the predicted value of $h p-h$ for each of the sets of characteristics shown in Table 3.3. Thus, when combining the relevant coefficients in Table 3.4, we find that women with the particular bundle of characteristics presented in the second row prefer to reduce their weekly working time by 5.1 hours $(-1.24-2.14-0.62-1.00-0.13=$ -5.13). In column 8 we add up the actual hours and desired change, to find the preferred working time. Column 9 shows the value of $h_{0}$ for each of the sets of characteristics, according to the parameter estimates in column 1 of Table 3.2. The final column shows the fraction of each subgroup that works longer hours than the $h_{0}$ of that subgroup. That is, we expect that about 93 percent of the women with a higher professional degree, who work in business services, are aged between 25-34 and live in a household without children, would like to reduce the actual weekly working hours.

Column 10 of Table 3.3 shows considerable heterogeneity in the fraction of women who have working hours beyond the value of $h_{0}$ of their type. We uncovered several patterns for the selected sample, which we will discuss in turn. Relative to those with an intermediate vocational diploma (mbo), higher-educated women work longer hours and prefer a larger reduction in weekly hours; yet, their number of preferred hours is higher, on average. These women are also more likely to work more than $h_{0}$ hours, suggesting they are more often inclined to reduce hours. Summary statistics from the LISS (2010 wave) confirm this pattern. About 59 percent of the women with a higher vocational degree $(\mathrm{N}=405)$, but only 35 percent of those with an intermediate vocational diploma $(\mathrm{N}=454)$, prefer to work fewer hours. Conditional on educational attainment, women in business services work longer hours per week and would like to reduce their hours more than the women working in health care and welfare. The former tend to prefer higher weekly hours, but the difference is modest. The percentages reported in column 10 of Table 3.3 are consistently higher for women in business services. Summary statistics again confirm the pattern. About 55 percent of the women working in business services ( $\mathrm{N}=89$ ) would like to reduce their hours, whereas only 40 percent among those in health care and welfare $(\mathrm{N}=475)$ would. 


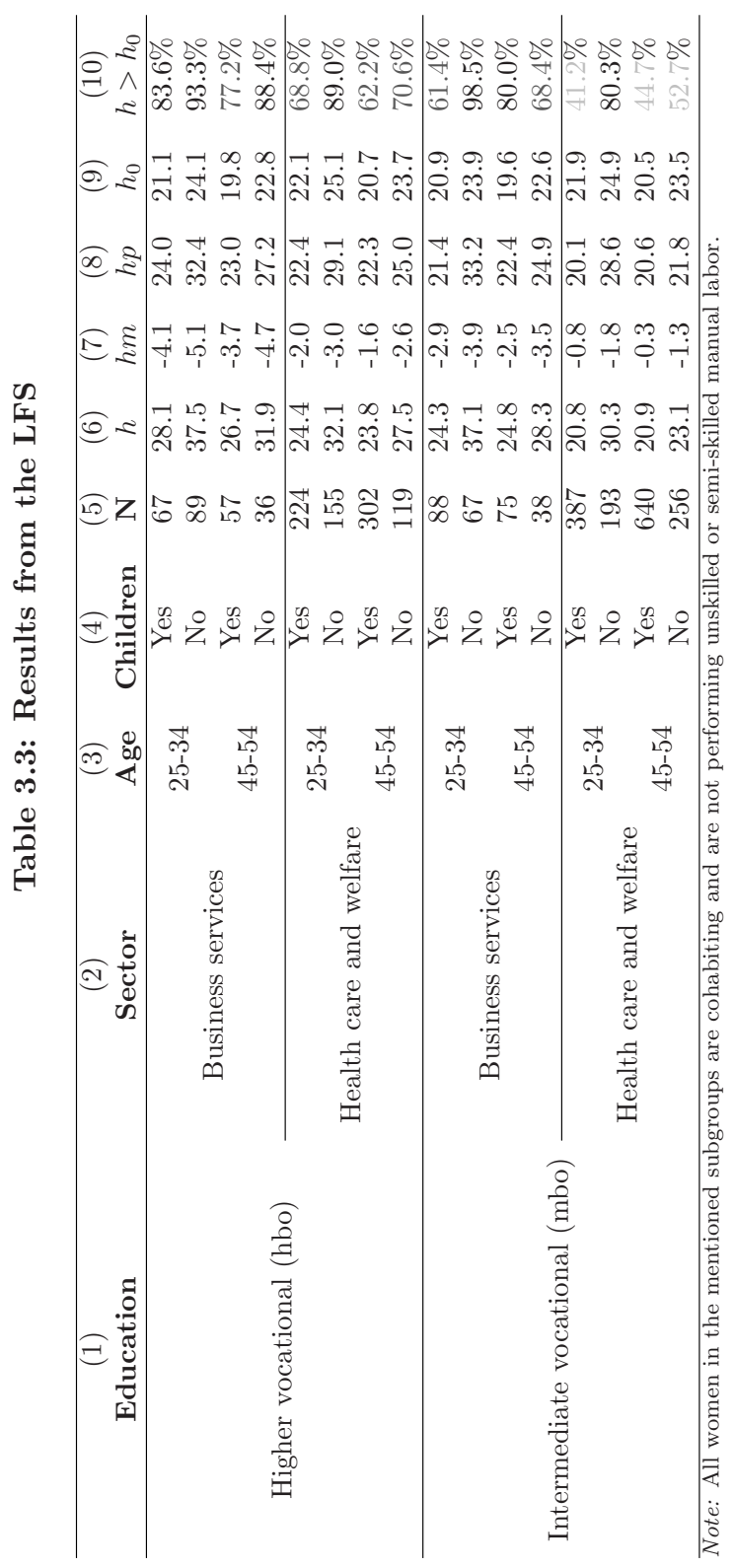


Table 3.4: Predicting the desired change in working hours $(\mathrm{hm})$

\begin{tabular}{|c|c|}
\hline Dependent variable: & $h m$ \\
\hline \multicolumn{2}{|l|}{ Education } \\
\hline Academic higher education & $\begin{array}{c}-2.01^{* * *} \\
(0.56)\end{array}$ \\
\hline Higher professional education & $\begin{array}{c}-1.24^{* * *} \\
(0.31)\end{array}$ \\
\hline Senior general secondary- or pre-university education & $\begin{array}{l}-0.22 \\
(0.43)\end{array}$ \\
\hline Preparatory secondary vocational education & $\begin{array}{c}0.40 \\
(0.35)\end{array}$ \\
\hline Primary or no education & $\begin{array}{l}-0.94 \\
(1.01)\end{array}$ \\
\hline \multicolumn{2}{|l|}{ Sector and type of work } \\
\hline Government services and public administration & $\begin{array}{l}-0.63 \\
(0.41)\end{array}$ \\
\hline Financial services & $\begin{array}{c}-0.90^{* *} \\
(0.45)\end{array}$ \\
\hline Business services & $\begin{array}{c}-2.14^{* * *} \\
(0.52)\end{array}$ \\
\hline Education & $\begin{array}{c}-2.78^{* * *} \\
(0.45)\end{array}$ \\
\hline Retail trade & $\begin{array}{l}-0.43 \\
(0.40)\end{array}$ \\
\hline Industrial production & $\begin{array}{c}-1.84^{* * * *} \\
(0.59)\end{array}$ \\
\hline Semi- or unskilled manual work & $\begin{array}{c}2.58^{* * *} \\
(0.47)\end{array}$ \\
\hline \multicolumn{2}{|c|}{ Demographics and household composition } \\
\hline Age 16-24 & $\begin{array}{c}1.03 \\
(0.71)\end{array}$ \\
\hline Age 25-34 & $\begin{array}{c}-0.62^{* *} \\
(0.31)\end{array}$ \\
\hline Age $45-54$ & $\begin{array}{l}-0.18 \\
(0.29)\end{array}$ \\
\hline Age 55-59 & $\begin{array}{c}-0.80^{*} \\
(0.42)\end{array}$ \\
\hline No child in the household & $\begin{array}{c}-1.00^{* * *} \\
(0.27)\end{array}$ \\
\hline Single & $\begin{array}{l}-0.48 \\
(0.35)\end{array}$ \\
\hline Constant & $\begin{array}{l}-0.13 \\
(0.33)\end{array}$ \\
\hline Number of observations & 4,468 \\
\hline Number of individuals & 2,226 \\
\hline
\end{tabular}

Note: Results of a random effects least-squares estimation with 2008-2010 LISS data. Cluster-robust standard errors are presented between parentheses. The superscripts $* * *, * *$, and $*$ indicate significance of the coefficients at the 1, 5, and 10 percent levels, respectively. The following reference groups are used: education, secondary vocational education; sector of employment, health care and welfare; type of job, no unskilled or semi-skilled manual work; age, 35-44 years old; household composition, cohabiting, with children living in the household; and month, April 2010. 
Conditional on the sector and educational attainment, younger women work longer hours than older women. The younger generation also prefers a higher reduction in weekly hours, whether there are children in the household or not. The main results in column 10 show that younger women work more than $h_{0}$ hours relatively more often. This indicates that the mismatch between actual and demanded hours, on the one hand, and preferred working hours, on the other hand, is expected to be more common for younger women. In the 2010 wave of the LISS, 54 percent of those in the younger generation $(\mathrm{N}=342)$ would like to work shorter hours; for the older generation $(\mathrm{N}=430)$, this percentage is 40 percent.

\subsection{Concluding remarks}

The current study shows that the equilibrium point where average actual working hours meet the preferred hours depends on individual characteristics. This heterogeneity is of interest to policymakers aiming to increase the total number of hours worked by women. This number is informative in two ways. First, it shows in what hour range we will find women who want to work longer and shorter hours. Second, we can calculate the relative sizes of these groups to examine the scope for policy. ${ }^{16}$

As a simple illustration, we compared two groups. They both work in the health care and welfare sector and have an intermediate vocational diploma. The first group is younger and does not have children, whereas the second, older group, does. We estimate $h_{0}$ to be equal to 24.9 (s.e. $=0.9$ ) for the first group and 20.5 $($ s.e. $=0.8)$ for the second. The difference between the two parameter estimates is different from zero at conventional levels of significance (p-value $<0.01$ ). Assume for this example that policymakers want to consider a supply-stimulating policy. Our estimates indicate that the labor supply of women in the former group should be stimulated if they work about 25 hours per week or more. Below this point ( $h$ $<25$ ), a supply-stimulating policy seems unnecessary, because we expect that the majority of women will be willing to work longer hours per week. The desire to decrease working hours for the latter group comes at about 21 hours already. So, the range of hours for which a supply-stimulating policy may be fruitful is wider for the group of older women with children. Yet, the scope for policy interventions (a supply-stimulating policy in this example) is much larger for the former group, since about 80 percent of these women work longer hours than their group's value of $h_{0}$, compared to about 45 percent in the latter group.

The instrument introduced by Booth and Van Ours (2013) and further developed in this paper can provide useful information to policymakers, since it presents an

\footnotetext{
${ }^{16}$ While the average effects of background characteristics on the desired change in hours (previous chapter of this dissertation) are informative, they do not disclose direct information on the sizes of the groups that want to work longer or shorter hours.
} 
hours range in which different policies aimed at increasing total working hours could be fruitful. Moreover, it approximates the scope for policy interventions (the fraction of a group with $h>h_{0}$ or $h<h_{0}$ ). Our study also implies that the goal of a supply-stimulating policy should not be to increase the hours worked of all working women in part-time jobs, as was the goal of the Task Force Part-time Plus (Ministry of Social Affairs, 2008). Our results imply that there are groups or types of workers who already prefer to increase the number of hours they work. Stimulating the supply of labor, in terms of preferred working hours, of these groups would, of course, be ineffective. To be successful, supply-stimulating and other policies should take into account heterogeneity of the type presented in this study. 


\section{The impact of changes in the standard workweek on preferences for labor supply ${ }^{1}$}

\subsection{Introduction}

Several theories point to the importance of reference effects in labor supply. ${ }^{2}$ In this chapter we study whether preferences for work and leisure of (former) West German civil servants (Beamte) and public sector employees (Angestellte im öffentlichen Dienst) changed in response to reductions and extensions in the length of the standard workweek. We examine whether changes in the standard working time in the public sector between 1989 and 2006, which were introduced staggeredly over time for different federal states (Bundesländer), affected stated preferences for work and leisure. In particular, we estimate a standard labor supply model in which we model an individual's preferred working hours as a function of the standard working time and other determinants of labor supply.

Our results indicate that the variations in the standard workweek significantly

\footnotetext{
${ }^{1}$ This chapter is based on joint work (in progress) with Thomas Dohmen and Maarten Vendrik. Earlier drafts of this chapter have been presented at the Conference of the European Association of Labour Economists (Bonn, Germany, 2012), the Conference of the European Economic Association (Málaga, Spain, 2012), the Conference of the European Society for Population Economics (Bern, Switzerland, 2012) and the Spring Meeting for Young Economists (Mannheim, Germany, 2012). I thank participants at these conferences, and Ulf Zölitz for discussion and comments. The data used in this study were extracted using the add-on-package PanelWhiz for Stata. See Haisken-DeNew and Hahn (2006) for details.

${ }^{2}$ Examples are preference interdependence (e.g., Blomquist, 1993) and habit formation (e.g., Vendrik, 1993).
} 
changed the preferences with respect to weekly working hours. A reduction in the standard workweek is followed by a strong contemporaneous decrease in preferred hours. However, in the subsequent years preferences partly revert back towards the old level, such that the long-run effect is smaller than the short-run effect. A workweek extension leads to a gradual increase in preferred weekly working time. That is, we find an asymmetry in the adjustment process of preferred labor supply for extensions and reductions of standard hours. The identified effects can potentially be accounted for by preferences that are subject to habit formation, preference interdependence, social norms and/or anchoring. ${ }^{3}$

We structure this chapter as follows. In Section 4.2 we briefly introduce the data used in this study, after which we discuss in detail the assignment to the standardhours regime in Section 4.3. In Section 4.4 we present descriptive evidence in favor of preference adjustment following changes in the standard working time. Section 4.5 introduces the econometric model. The estimation results are presented in Section 4.6. In Section 4.7 we perform some robustness checks. Section 4.8 discusses the results. Section 4.9 presents a short summary and concludes.

\subsection{Data}

The data used in this study come from the German Socio-Economic Panel Study (SOEP), waves 1985 to 2009. The dependent variable in our analysis are the preferred weekly working hours (denoted $h p$ ). Preferred-hours data are available in all waves of the SOEP, except for 1996. Respondents were asked the following question: "If you could choose your own number of working hours, taking into account that your income would change according to the number of hours: How many hours would you want to work?" 4 We assume that individuals answer the question having their contractual hourly wage in mind. ${ }^{5}$ One might be skeptical to draw conclusions from subjective data of this kind. However, Euwals et al. (1998) show that, in addition to qualitative information, self-reported preferred hours predict future actual hours.

The independent variable of interest is the standard working time. We merge data on the length of the standard workweek to the SOEP data. State-specific information on the length of the workweek of public sector employees was provided by Ver.di, the labor union in which public sector employees are organized. ${ }^{6}$

\footnotetext{
${ }^{3}$ We discuss these phenomena more in detail during the discussion.

${ }^{4}$ In the German version of the questionnaire, the question was phrased as follows: "Wenn Sie den Umfang Ihrer Arbeitszeit selbst wählen könnten und dabei berücksichtigen, daß sich Ihr Verdienst entsprechend der Arbeitszeit ändern würde: Wie viele Stunden in der Woche würden Sie dann am liebsten arbeiten?"

${ }^{5} \mathrm{I}$ calculate the contractual hourly wage as $\frac{Y_{L}}{h c * \times 4 \frac{1}{3}}$, where $Y_{L}$ and $h c$ represent monthly individual labor earnings and working hours stipulated in the contract, respectively.

${ }^{6}$ Even if, on the level of collective decision making, the changes in the standard workweek were
} 
$\underline{4}$ The impact of changes in the standard workweek on preferences for labor supply

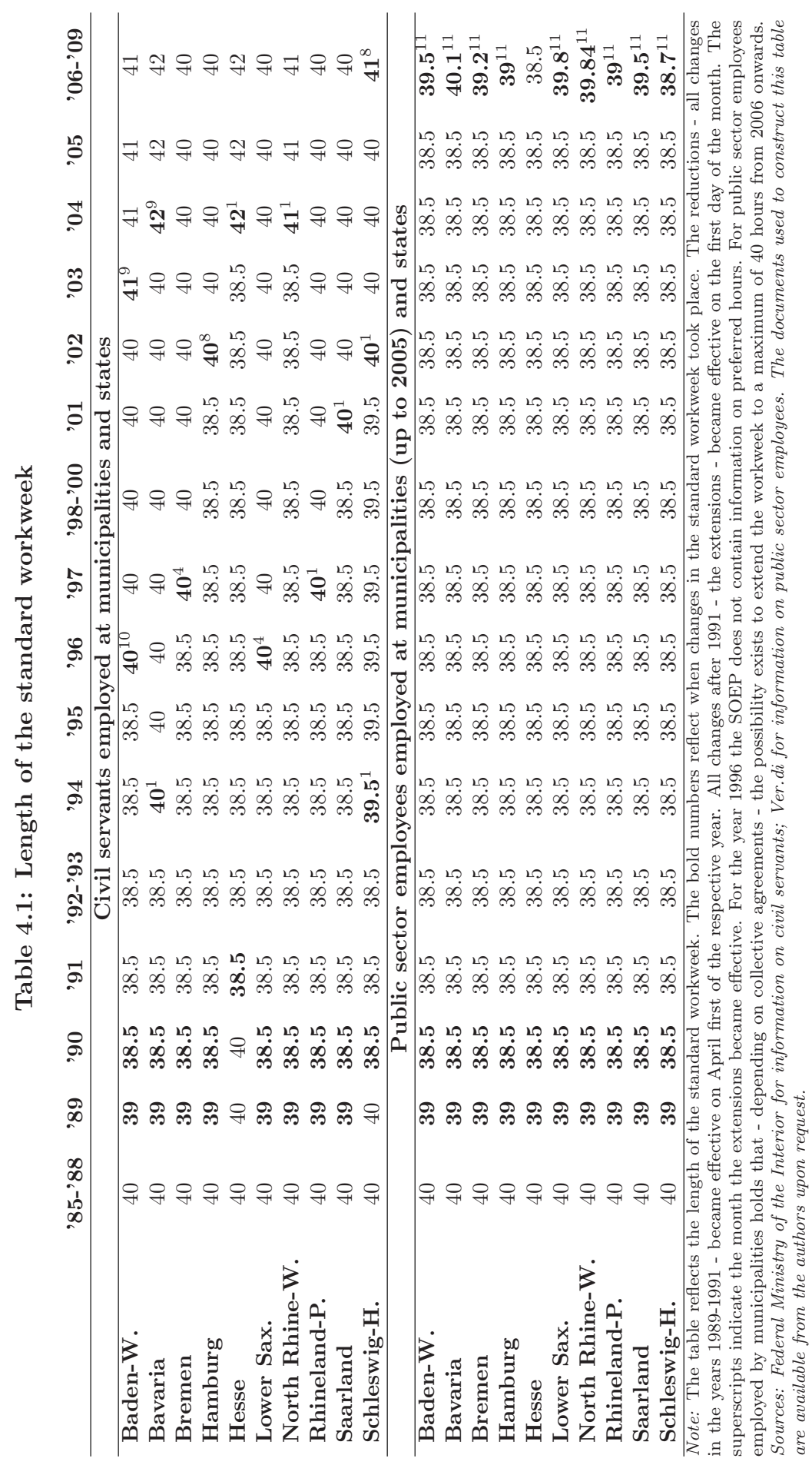




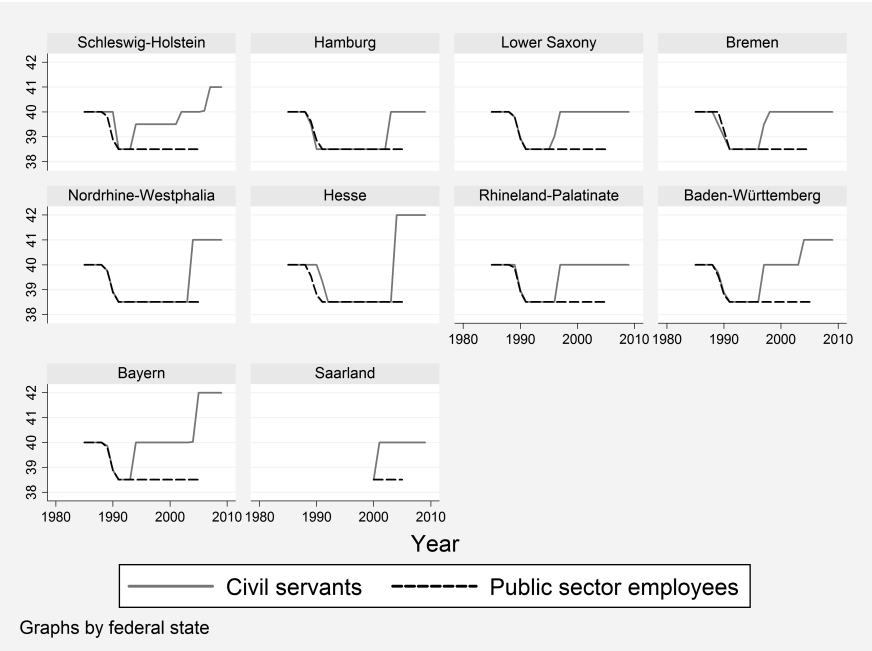

Figure 4.1: Length of the standard workweek for civil servants and public sector employees in West-German federal states

Note: This figures shows the length of the standard workweek for civil servants and public sector employees for all West-German federal states. For civil servants we present data for the years 1985-2009, whereas for the public sector employees we present data for the years 1985-2004. Source: Federal Ministry of the Interior and Ver.di.

Information on the length of the standard workweek of civil servants was provided by the Federal Ministry of the Interior. Table 4.1 and Figure 4.1 provide an overview of these numbers. These reveal that there is a period of shortening of the standard workweek (1989-1992) followed by a period of lengthening. Prior to 1992 all employees in the public service experienced a reduction in the standard working time from 40 to 38.5 hours. For civil servants in Schleswig-Holstein the reduction from 40 to 38.5 hours became effective in April 1990 and for those in Hesse in April 1991. For all remaining civil servants and all public sector employees the reductions became effective in a staggered fashion. In April 1989 the full-time workweek was shortened by one hour to 39 hours. Exactly one year later (April 1990) it was shortened by an additional half hour to a standard full-time workweek of 38.5 hours. From 1994 civil servants in all states experienced one or several prolongations of the standard workweek, resulting in a standard workweek of up to 42 hours per week in Hesse and Bavaria.

We restrict our sample to individuals between the ages of 15 and 49 (inclusive) who are regularly employed as either civil servant or public sector employee. We exclude employees aged 50 and older from the sample, because these workers are eligible for special arrangements with respect to weekly hours. Furthermore, we exclude all individuals in full-time education, individuals with an additional job, and those who reported (preferred) hours of more than 84 per week (seven times

partially based on individual labor supply preferences they can be regarded as exogenous because the influence of each individual's preference separately on the standard workweek is negligible. 
$\underline{4 \text { The impact of changes in the standard workweek on preferences for labor supply }}$

half a natural day). Finally, we should note that before the year 2000, we are unable to discriminate between individuals living in Saarland and Rhineland-Palatinate. Since the inhabitants of Saarland constitute only a minor fraction of the sample, we neglect this issue.

\subsection{Assignment to standard-hours regime}

The SOEP does not contain information about the standard workweek people are subject to. We therefore have to assign the correct standard workweek length to the right individuals. This exercise is hampered by the fact that there can exist differences in the standard workweek between people employed at federal government bodies, states and municipalities. We briefly highlight these differences for civil servants and public sector employees in turn.

For civil servants there are differences in the standard workweek only between those employed at states and municipalities (Landesbeamte and Kommunalbeamte) on the one hand, and those employed at the federal level (Bundesbeamte) on the other hand. Tables 4.1 and 4.2 reveal these differences. In fact, the timing of workweek reductions is identical for most civil servants, while the timing of the workweek extensions after 1994 is not. For example, civil servants employed at the federal level experienced extensions in the standard workweek in 2004 and 2006, whereas civil servants employed at several states and municipalities experienced such extensions in the pre-2004 period already.

Whereas civil servants employed at states and municipalities do not differ with respect to their standard workweek length, these differences can be present for public sector employees. Even though the timing of the 1989-reductions is identical for all public sector employees, there exist differences with respect to the extensions (Tables 4.1 and 4.2). Public sector employees employed by federal bodies experienced a half-an-hour extensions in October 2005, whereas those employed by states experienced extensions over a year later (November 2006). Public sector employees employed by municipalities may have been subject to a higher level of standard hours (up to 40) from October 2005 onwards, depending on bargaining agreements (not presented in Table 4.2).

Unfortunately, the SOEP data lack information that explicitly indicates whether a civil servant or public sector employee is employed at a federal body, a state or a municipality. As a result, we cannot unambiguously assign the relevant standard workweek to all individuals. Since the vast majority of civil servants is employed at states/municipalities (German Federal Statistical Office, 2011), we maintain the assumption that all civil servants are subject to the state-level standard-workweek regulations prevailing in the state they reside in. In fact, we maintain the same assumption for public sector employees. However, in case of the public sector employees, the ratio of municipal-to-state employed is about fifty-fifty (German 
Table 4.2: Length of the standard workweek for employees in public service at the federal and municipal level.

\begin{tabular}{|c|c|c|c|c|c|c|c|c|}
\hline & '85-'88 & '89 & '90 & '91-’03 & '04 & '05 & '06 & '07-’09 \\
\hline & \multicolumn{8}{|c|}{ Civil servants } \\
\hline Federal bodies & 40 & 39 & 38.5 & 38.5 & $40^{10}$ & 40 & $41^{3}$ & 41 \\
\hline & \multicolumn{8}{|c|}{ Public sector employees } \\
\hline Federal bodies & 40 & 39 & 38.5 & 38.5 & 38.5 & $39^{10}$ & 39 & 39 \\
\hline Municipalities & 40 & 39 & 38.5 & 38.5 & 38.5 & 38.5 & 38.5 & 38.5 \\
\hline
\end{tabular}

Note: See note to Table 4.1. From October first 2005 onwards there were special rules for public sector employees employed by municipalities. Depending on negotiations the option exists to extend the workweek to 40 hours per week.

Federal Statistical Office, 2011). Thus, assuming all employees are subject to the length of the standard workweek prevalent in a particular state would introduce considerable noise after 2005. Therefore, we set the variable measuring the length of the standard workweek to missing for those public sector employees interviewed in October 2005 and after. ${ }^{7}$

\subsection{Descriptive evidence for preference adjustment}

In Figure 4.2 we present the series of average actual, preferred, standard and contractual hours (denoted $h, h p, h s$ and $h c$ respectively) for the selected sample. ${ }^{8}$ Panel (a) presents the series for men and panel (b) presents them for women. The standard-hours series illustrate the length of one full-time equivalent at the time of completing the interview. Given that individuals are not interviewed in the same month and because we average data across several states, the average length of the standard workweek changes smoothly. The series of actual hours worked is more erratic. Nevertheless, the co-movement of actual hours and the standard workweek in Panel (a) of Figure 4.2 suggests that working hours are affected by the standard workweek.

The pattern in Panel (b) is less clear cut. Comparing the series of female civil servants and public sector employees, it seems that working time preferences of the former remain rather stable, whereas preferred hours of the latter group tend to slope downward. This gradual reduction in preferred working time likely reflects the decreasing propensity for women to work in full-time jobs. About 72 percent of

\footnotetext{
${ }^{7}$ Indeed, when we include public sector employees and assume that they are subject to the length of the standard workweek prevalent in the state, we find - as expected - that the effect size decreases slightly. Yet, the results remain qualitatively unchanged.

${ }^{8}$ The following questions were used for eliciting the contractual and actual weekly working hours: "How many hours are stipulated in your contract (excluding overtime)?", followed by "And how many hours do your actual working-hours consist of including possible over-time?" Following the advice of members of the SOEP team, we present the generated actual hours variable.
} 
4 The impact of changes in the standard workweek on preferences for labor supply

women in the public sector in our sample reported to work full-time in 1985. This fraction gradually fell to 48 percent in 2009.

\subsubsection{Reductions in the length of the standard workweek}

In Panel (a) of Figure 4.3 we plot the development of the averages of standard and preferred hours around the time of the reductions in the standard working time. Because civil servants and public sector employees experienced the change at the same point in time, we combine the information for both groups in one graph. The two vertical red lines indicate the years in which most states introduced the shorter workweek (1989 and 1990). An exception is Hesse. The standard workweek for Hesse civil servants was reduced only in April 1991. For ease of exposition, we lag the data series underlying Panel (a) of Figure 4.3 for civil servants in Hesse by one year (i.e. 1991 becomes 1990; 1990 becomes 1989 etcetera), ${ }^{9}$ so that the year 1989 in the figure corresponds to the year in which the standard workweek was shortened.

Note that Panel (a) of Figure 4.3 plots the average of the standard workweek that applied to respondents at the time of the interview. Roughly 77 percent of the respondents to the 1989 wave of the SOEP were interviewed before the change in the standard workweek became effective (i.e. before April), which causes the entire change in the standard and actual hours to be visible only in 1990, when the new standard working hours applied to all respondents.

From Panel (a) we observe that the preferred hours remained quite stable in the years before the first shortening. However, the year after the first reduction became effective we observe a sizable drop in preferred hours. The pattern in preferred hours revealed in Panel (a) suggests that preferences adjusted to changes in the standard workweek, at least in the short-run. It seems that preferred hours gradually increased towards the old level after some years. On the one hand, such a reversion could reflect that preferences are only affected temporarily by a change in the standard working time. On the other hand, it could reflect changing determinants of labor supply in the underlying sample. Given the development of the preferred-hours series of male civil servants from the mid-90s onwards, the first explanation seems unlikely, as preferred hours in Panel (a) of Figure 4.2 do not seem to revert to some old level. Rather, they are correlated over time with standard and actual hours.

\footnotetext{
${ }^{9}$ Of course, strictly speaking we neglect year-specific effects here. However, this presentation facilitates the graphical analysis.
} 


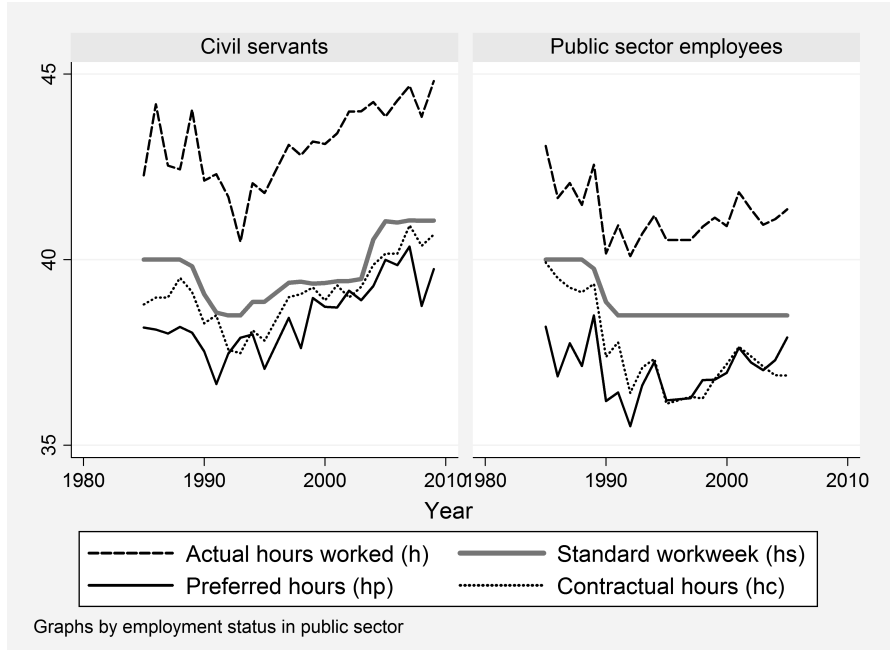

(a) Men

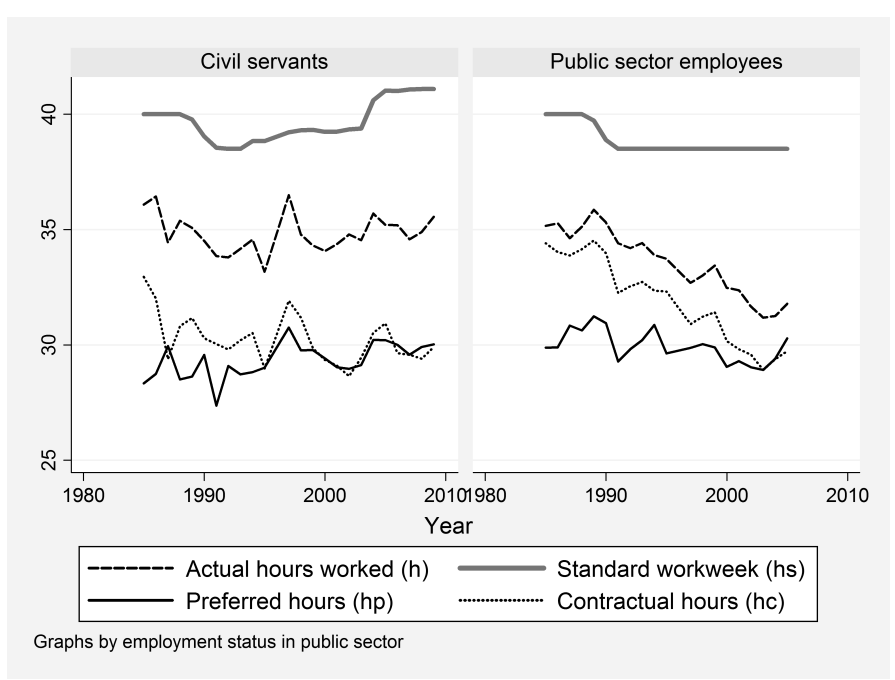

(b) Women

Figure 4.2: Series of standard, actual, contractual and preferred weekly hours, by gender

Note: In this figure we present the cross-sectionally averaged preferred and standard hours, along with contractual and actual hours worked. The time series of civil servants and public sector employees are presented on the left and right hand side respectively. We assume that an individual living in a certain state is subject to the length of the standard working time in that state. 


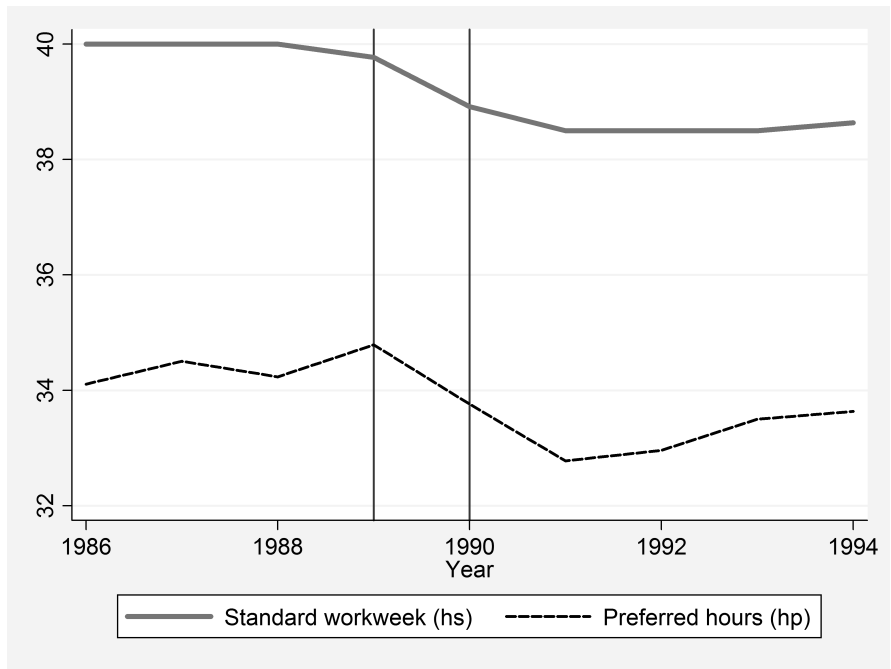

(a) Shortening of standard workweek for Beamte and Angestellte

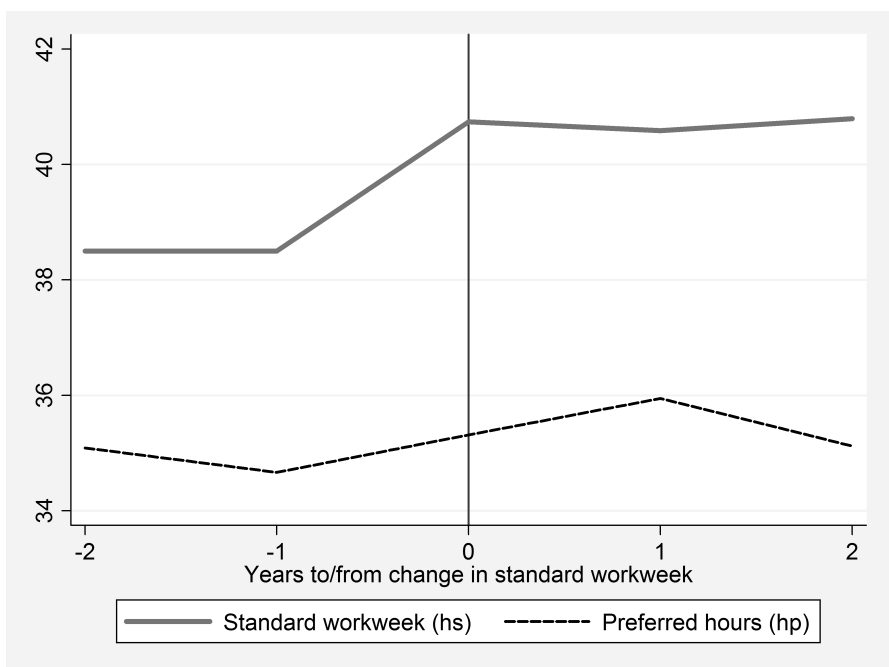

(b) Lengthening of standard workweek for Beamte

\section{Figure 4.3: The effects of a shortening and lengthening of the standard workweek}

Note: Panel (a) plots the cross-sectionally averaged preferred and standard hours for the period in which all employees in the public sector experienced a shortening of the standard workweek. The two vertical lines indicate the years in which the shortenings became effective. The shortening in the standard workweek for Hesse civil servants occurred only on April 1, 1991. We take this into account by taking a one-year lag of the data series for civil servants in Hesse (i.e. 1991 becomes 1990; 1990 becomes 1989 etcetera). Panel (b) plots the cross-sectionally averaged preferred and standard hours for the period in which many civil servants experienced a lengthening in the length of the standard workweek. Since the extensions did not take effect at the same point in time we construct a variable that measures the years to and from the extension in standard working time which is measured on the $\mathrm{x}$-axis. 


\subsubsection{Extensions of the standard workweek}

Contrary to the reductions, the extensions did not take effect at the same point in time for all civil servants and public sector employees. In order to compare the development of the averages of $h p$ and $h s$ after workweek extensions we construct a variable measuring the years to/from the extension. For all federal states listed in Table 4.1 we exploit the first workweek extension, the increases from 38.5 to either 39.5, 40 or 42 hours. The averages of standard and preferred hours are presented in Panel (b) of Figure 4.3. In the raw data, the increase in preferred hours seems only small, relative to the increase in standard hours between $t=-1$ and $t=1$. After $t=1$ average preferred hours decrease towards the level of $t=-1$. However, note that Figure 4.3 only represents raw data, and does not take into account background characteristics.

\subsubsection{Reductions and extensions quantified}

In column 1 of Table 4.3 we present the regression coefficients of a fixed-effects regression of a change in the length of the standard workweek on preferred hours. We find that an increase in the length of the standard workweek is associated with an increase in preferred hours of about half an hour. In column 2 we allow for a lagged effect, as is common in the habit-formation literature. We do not find evidence in favor of such an effect, as the coefficient is quantitatively small and statistically insignificant.

To test whether preferences adjust differently to reductions and extensions of the standard workweek, as Figure 4.3 suggests, we allow for the coefficient on the standard workweek $(h s)$ to differ between periods of workweek shortenings (i.e. year $\leq 1993$ ) and periods of expansions of the standard workweek (i.e. year $>$ 1994). The results presented in column 3 of Table 4.3 indicate that both effects are of comparable magnitude, suggesting that the effect found in column 1 is driven by reductions as well as extensions.

\subsection{Augmented standard labor supply model}

In this section we augment the standard labor supply model to test whether preferred working hours are affected by changes in the standard working time. We model preferred hours $(h p)$ to linearly dependent on background characteristics (cf. Hausman and Ruud, 1984) and current and lagged standard hours $(h s) .{ }^{10}$ In the

\footnotetext{
${ }^{10}$ Woittiez and Kapteyn (1998) estimate a similar model to test for the effect of past hours worked and hours worked in the reference group on current preferences. In addition, the authors estimate a participation equation. We focus on a group of workers who faced a change in the standard working time, and therefore do not estimate a participation equation.
} 
4 The impact of changes in the standard workweek on preferences for labor supply

Table 4.3: The effect of changes in the standard workweek

\begin{tabular}{lccc}
\hline & $(1)$ & $(2)$ & $(3)$ \\
Dependent variable: & $h p$ & $h p$ & $h p$ \\
\hline Standard workweek $\left(h s_{t}\right)$ & $0.48^{* * *}$ & $0.38^{* * *}$ & \\
& $(0.12)$ & $(0.14)$ & \\
L.Standard workweek $\left(h s_{t-1}\right)$ & & 0.08 & \\
& & $(0.13)$ & \\
$h s_{t} \times \mathbf{1}($ year $\leq \mathbf{1 9 9 3})$ & & $0.43^{* * *}$ \\
& & & $(0.12)$ \\
$h s_{t} \times \mathbf{1}($ year $>\mathbf{1 9 9 3})$ & & & $0.45^{* * *}$ \\
& & & $(0.12)$ \\
\hline Number of observations & 18,325 & 13,125 & 18,325 \\
Number of individuals & 4,106 & 2,935 & 4,106 \\
\hline
\end{tabular}

Note: Regression coefficients of a fixed-effects estimation of $h p$ on $h s$ without additional controls. The constant has been suppressed. In column (1) we regress current $h p$ on current $h s$. In column (2) we allow for a lagged effect of standard hours, $h s(t-1)$, on current $h p$. In column (3) we allow for asymmetric effects. Robust standard errors are reported in parentheses

graphical analysis we observed that preferred hours are rather volatile. In Panel (a) of Figure 4.3, after preferences adjust to the new workweek, they seem to revert back to the old level. This reversion could simply reflect changes in (average) determinants of labor supply in the sample. It could also be that preferences are in the long run - not affected by a change in the standard workweek. To test for the possibility of reversion, we add lagged $h s$-terms as explanatory variables in a stepwise fashion to our basic model, which we specify as

$$
h p_{i t}=\beta_{0} h s_{i t}+\boldsymbol{\beta}^{\prime} \mathbf{x}_{\mathbf{i t}}+\epsilon_{i t},
$$

where individual $i$ in period $t$ is subject to the standard workweek of length $h s$. The column vector $\mathbf{x}_{\mathbf{i t}}$ contains individual characteristics relevant for labor supply decisions, a constant, and lagged regressors. ${ }^{11}$

The contemporaneous effect of a change in the standard workweek in a model without lagged $h s$-variables is now easily identified as $\frac{\partial h p_{i t}}{\partial h s_{i t}}=\beta_{0}$, the coefficient of the length of the standard workweek. We assume that the error term contains an individual-specific component $\theta_{i}: \epsilon_{i t}=\theta_{i}+\nu_{i t}$ which captures time-invariant unobserved factors that affect $h p_{i t}$. The residual $\nu_{i t}$ is assumed to be white noise. Estimating Model 4.1 with fixed effects eliminates the time-invariant component $\theta_{i}$.

\footnotetext{
${ }^{11}$ Habit formation models usually only include a lagged term, most often a lagged dependent variable. This setup implies that one is unable to measure habit formation within a year's time. In our case we allow for a contemporaneous effect of $h s$ on $h p$.
} 


\subsection{Results}

In column 1 of Table 4.4 we present the results of the asymmetric model presented in column 3 of Table 4.3, augmented with control variables. ${ }^{12}$ Since we want to control for a time trend, we add age dummies in the estimations, instead of a continuous age variable. We allow for a separate linear trend for women to reflect the gradual reduction in the propensity to work full-time among women, as discussed earlier. Including controls in the regression reduces the effect of changes in the standard workweek on preferred hours by about a third, compared to the model without controls. That is, a one-hour change in the length of the standard workweek leads to a change in preferred hours worked of about twenty minutes ( 0.32 hours) in the same direction. ${ }^{13}$

The result from section 4.4.3 suggests that the adjustment process of preferences is similar for reductions and extensions. Yet, the patterns in Figure 4.3 seem to differ. To test whether the adjustment processes following extensions and reductions are the same, we now add lagged $h s$-terms for both periods (i.e. the period during which only reductions became effective and the period during which only extensions became effective). Whenever we include lagged values of the $h s$-terms, we include lagged values (of the same lag length) of all other explanatory variables as well.

Since there are no a priori candidates for a suitable lag-length, we perform two types of lag length selection tests. For both tests we start with a fairly general model that includes three lags and - in a stepwise fashion - reduce the lag length until we end up with our preferred specification.

In the first set of tests we test the significance of the lagged explanatory variables as follows. We run the regression including three lags. We then test the joint significance of all highest-order lagged explanatory variables (null hypothesis: all highest-order lagged effects are jointly zero), including the $h s$-terms of that order. If this test fails to reject the null-hypothesis that lagged variables affect contemporaneous preferred hours at the 10-percent level, we perform the same test on the highest-order lagged $h s$-terms only (null hypothesis: all highest-order lagged $h s$-terms are zero). If this test also fails to reject insignificance (p-value $>0.1$ ) all highest-order lags are omitted from the model and we repeat the same set of tests on the resulting model. As a second test we rely on the comparison of the Akaike and Schwarz Information Criterion (AIC and SIC, respectively) to select between models.

\footnotetext{
${ }^{12}$ The set of control variables included in the estimation consists of the (natural log of) the wage rate, the other income in the household, education and age dummies, the number of children below the age of 16 in the household, a dummy variable indicating whether someone lives with a spouse or not, a linear trend, and a trend interacted with a female dummy.

${ }^{13}$ Estimating the model with contemporaneous control variables only for females and males separately indicates that the effects of reductions as well as prolongations are larger for females $(0.31$ ( $\mathrm{p}$-value $<0.1)$ and 0.31 ( $\mathrm{p}$-value $<0.1)$ respectively) than for males $(0.26(\mathrm{p}$-value $<0.05)$ and 0.24 (p-value $<0.05)$ respectively), but less significant.
} 
Both information criteria in the second set of tests favor the model without lags. According to the tests, the higher-order explanatory variables do not explain enough variation to justify their inclusion in the model. ${ }^{14}$ Yet, the first set of hypothesis tests leads to a different conclusion. For the model with three lagged explanatory variables the highest-order lags (jointly), as well as the highest-order lagged $h s$ terms in isolation, are insignificant ( $\mathrm{p}$-value $>0.1$ ). However, when estimating the model with two lags the test rejects the (joint) insignificance of all highestorder lagged explanatory variables at conventional significance levels. Since the explanatory variables of interest in the model with second-order lags are significant, we retain the two-lag model as our preferred specification. The results of this estimation are presented in column 3 of Table 4.4.

Table 4.4: Main results

\begin{tabular}{|c|c|c|c|}
\hline & (1) & $(2)$ & $(3)$ \\
\hline Dependent variable: & $h p$ & $h p$ & $h p$ \\
\hline$h s_{t} \times \mathbf{1}($ year $\leq 1993)$ & $\begin{array}{c}0.32^{* * *} \\
(0.11)\end{array}$ & $\begin{array}{c}0.85^{* * *} \\
(0.30)\end{array}$ & $\begin{array}{l}0.75^{* *} \\
(0.31)\end{array}$ \\
\hline$h s_{t-1} \times \mathbf{1}($ year $\leq \mathbf{1 9 9 3})$ & & $\begin{array}{c}-0.53^{*} \\
(0.28)\end{array}$ & $\begin{array}{l}-0.17 \\
(0.37)\end{array}$ \\
\hline$h s_{t-2} \times \mathbf{1}($ year $\leq \mathbf{1 9 9 3})$ & & & $\begin{array}{l}-0.29 \\
(0.29)\end{array}$ \\
\hline$h s_{t} \times \mathbf{1}($ year $>1993)$ & $\begin{array}{c}0.32^{* * *} \\
(0.11)\end{array}$ & $\begin{array}{c}0.23 \\
(0.15)\end{array}$ & $\begin{array}{c}0.05 \\
(0.16)\end{array}$ \\
\hline$h s_{t-1} \times \mathbf{1}($ year $>1993)$ & & $\begin{array}{c}0.07 \\
(0.15)\end{array}$ & $\begin{array}{l}-0.01 \\
(0.16)\end{array}$ \\
\hline$h s_{t-2} \times \mathbf{1}($ year $>1993)$ & & & $\begin{array}{l}0.23^{*} \\
(0.14)\end{array}$ \\
\hline Natural log of net hourly wage & $\begin{array}{c}-2.59^{* * *} \\
(0.43)\end{array}$ & $\begin{array}{c}-2.61^{* * *} \\
(0.53)\end{array}$ & $\begin{array}{c}-2.50 * * * \\
(0.65)\end{array}$ \\
\hline Net other income, thousands per week & $\begin{array}{c}-1.96^{* * *} \\
(0.51)\end{array}$ & $\begin{array}{c}-1.66^{* * * *} \\
(0.46)\end{array}$ & $\begin{array}{c}-1.32^{* *} \\
(0.59)\end{array}$ \\
\hline Unknown education (Yes $=1$, Vocational is base) & $\begin{array}{c}-0.21 \\
(0.48)\end{array}$ & $\begin{array}{c}-0.73 \\
(0.53)\end{array}$ & $\begin{array}{l}-0.65 \\
(0.57)\end{array}$ \\
\hline College education (Yes $=1$, Vocational is base) & $\begin{array}{c}2.54^{* * * *} \\
(0.65)\end{array}$ & $\begin{array}{c}0.33 \\
(0.94)\end{array}$ & $\begin{array}{l}-0.60 \\
(1.02)\end{array}$ \\
\hline Age $<35($ Yes $=1)$ & $\begin{array}{l}-0.40 \\
(0.27)\end{array}$ & $\begin{array}{l}-0.05 \\
(0.33)\end{array}$ & $\begin{array}{l}-0.27 \\
(0.38)\end{array}$ \\
\hline Age $>44($ Yes $=1)$ & $\begin{array}{c}0.33 \\
(0.23)\end{array}$ & $\begin{array}{c}0.65^{* *} \\
(0.29)\end{array}$ & $\begin{array}{c}0.72^{* *} \\
(0.30)\end{array}$ \\
\hline Children under 16 in household (Yes=1) & $\begin{array}{c}-2.82^{* * *} \\
(0.28)\end{array}$ & $\begin{array}{c}-1.86^{* * *} \\
(0.33)\end{array}$ & $\begin{array}{c}-1.55^{* * * *} \\
(0.36)\end{array}$ \\
\hline Trend & $\begin{array}{c}0.07^{*} \\
(0.04)\end{array}$ & $\begin{array}{c}0.03 \\
(0.05)\end{array}$ & $\begin{array}{c}0.02 \\
(0.06)\end{array}$ \\
\hline Trend $\times 1[$ female $]$ & $\begin{array}{c}-0.23^{* * *} \\
(0.04)\end{array}$ & $\begin{array}{c}-0.18^{* * *} \\
(0.05)\end{array}$ & $\begin{array}{c}-0.17^{* * *} \\
(0.06)\end{array}$ \\
\hline
\end{tabular}

Continued on next page

\footnotetext{
${ }^{14}$ From three to zero lags, the AIC and SIC are in turn: $35,754,35,744,35,734$ and 35,731 ; $36,038,35,960,35,882$ and 35,812 . To be able to compare the information criteria across different regressions, we estimated the different models on only those observations included in the model containing three lags of all explanatory variables.
} 
Table 4.4: Main results (continued from previous page)

\begin{tabular}{|c|c|c|c|}
\hline & (1) & $(2)$ & $(3)$ \\
\hline Dependent variable: & $h p$ & $h p$ & $h p$ \\
\hline Lives with spouse $($ Yes $=1)$ & $\begin{array}{c}-0.92^{* * *} \\
(0.30)\end{array}$ & $\begin{array}{l}-0.30 \\
(0.32)\end{array}$ & $\begin{array}{l}-0.30 \\
(0.34)\end{array}$ \\
\hline L.Wage & & $\begin{array}{c}0.37 \\
(0.45)\end{array}$ & $\begin{array}{c}0.42 \\
(0.56)\end{array}$ \\
\hline L.Other income & & $\begin{array}{l}-0.52 \\
(0.59)\end{array}$ & $\begin{array}{l}-0.32 \\
(0.52)\end{array}$ \\
\hline L.Education unknown & & $\begin{array}{c}0.65 \\
(0.56)\end{array}$ & $\begin{array}{c}0.31 \\
(0.87)\end{array}$ \\
\hline L.College education & & $\begin{array}{l}1.59^{*} \\
(0.86)\end{array}$ & $\begin{array}{c}1.18 \\
(0.93)\end{array}$ \\
\hline L.Age $<35$ & & $\begin{array}{l}-0.46 \\
(0.33)\end{array}$ & $\begin{array}{l}-0.14 \\
(0.38)\end{array}$ \\
\hline L.Age $>44$ & & $\begin{array}{l}-0.03 \\
(0.30)\end{array}$ & $\begin{array}{c}0.10 \\
(0.30)\end{array}$ \\
\hline L.Children & & $\begin{array}{c}-0.67^{* *} \\
(0.31)\end{array}$ & $\begin{array}{l}-0.30 \\
(0.39)\end{array}$ \\
\hline L.Spouse & & $\begin{array}{l}-0.45 \\
(0.34)\end{array}$ & $\begin{array}{l}-0.11 \\
(0.36)\end{array}$ \\
\hline L2. Wage & & & $\begin{array}{l}-0.53 \\
(0.56)\end{array}$ \\
\hline L2.Other income & & & $\begin{array}{c}-1.29^{* *} \\
(0.51)\end{array}$ \\
\hline L2.Education unknown & & & $\begin{array}{c}0.53 \\
(0.78)\end{array}$ \\
\hline L2.College education & & & $\begin{array}{c}0.49 \\
(0.66)\end{array}$ \\
\hline L2.Age $<35$ & & & $\begin{array}{l}-0.56 \\
(0.35)\end{array}$ \\
\hline L2.Age > 44 & & & $\begin{array}{l}-0.09 \\
(0.30)\end{array}$ \\
\hline L2.Children & & & $\begin{array}{l}-0.52 \\
(0.34)\end{array}$ \\
\hline L2.Spouse & & & $\begin{array}{l}-0.03 \\
(0.35)\end{array}$ \\
\hline Constant & $\begin{array}{c}29.73^{* * *} * \\
(4.50)\end{array}$ & $\begin{array}{c}29.84^{* * *} \\
(5.40)\end{array}$ & $\begin{array}{c}32.63^{* * *} \\
(6.61)\end{array}$ \\
\hline Number of observations & 16,645 & 11,602 & 8,471 \\
\hline Number of individuals & 3,813 & 2,660 & 1,909 \\
\hline$\Sigma h s$-terms pre-1993 & $0.32^{* * *}$ & $0.31^{* *}$ & $0.29^{*}$ \\
\hline$\sum h s$-terms post-1993 & $0.32^{* * *}$ & $0.31^{* *}$ & $0.28^{*}$ \\
\hline H0: highest-order lags equal zero (p-value) & - & 0.08 & 0.05 \\
\hline
\end{tabular}

Note: Results of a fixed-effects estimation of Model 4.1. Robust standard errors are reported in parentheses. The asterisks $* * *, * *$ and $*$ indicate significance at the 1-, 5- and 10-percent level. 


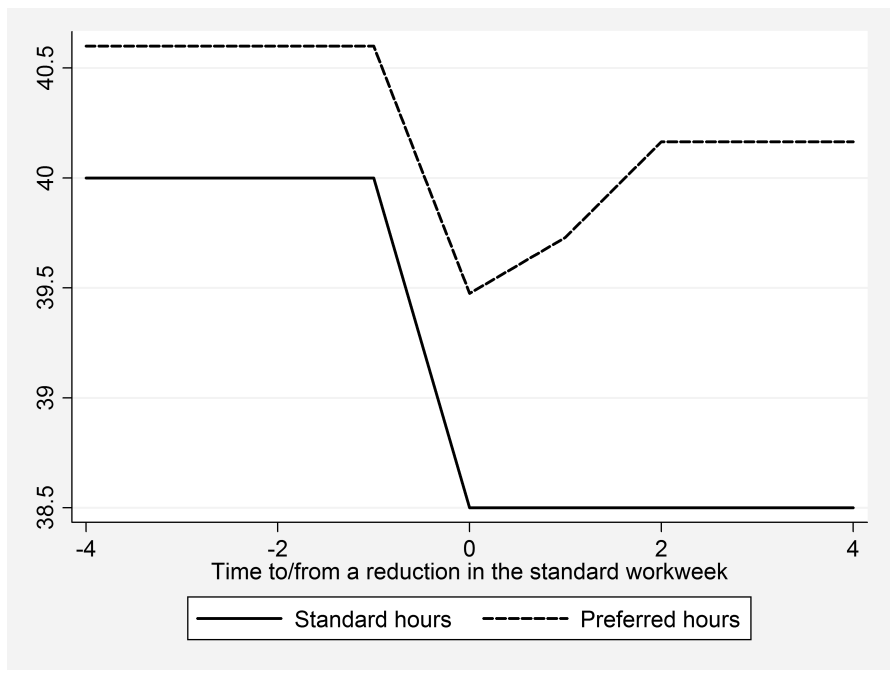

(a) Shortening of standard workweek

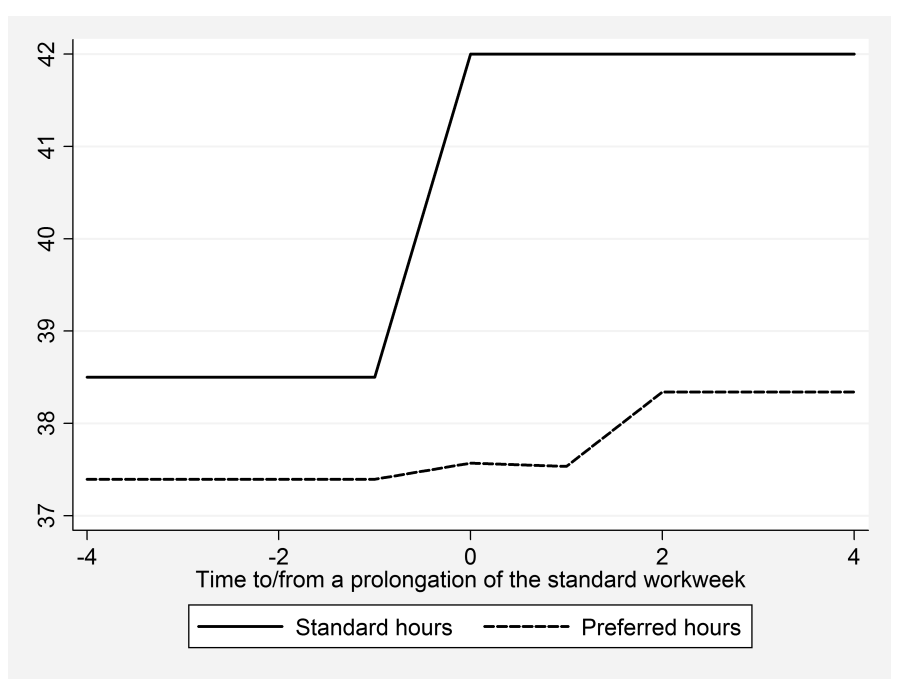

(b) Lengthening of standard workweek

Figure 4.4: The effects of a shortening and lengthening of the standard workweek

Note: Using the coefficients estimated in column 3 of Table 4.4 we graphically present the effect of a one-hour shortening and lengthening in the standard working time on preferred hours worked (keeping everything else constant). 
According to the two-lags model, a standard workweek reduction (pre-1993) is followed by a strong drop in preferred hours. However, the contemporaneous effect (0.75) overshoots the long-run effect, which is just over a third of the contemporaneous effect and is significant at the 10 -percent level $(0.29$; p-value $=$ 0.06). That is, a one-hour reduction in $h s$ leads to a decrease in preferred labor supply of just under twenty minutes per week.

For extensions of the standard workweek (post-1993) the adjustment process of preferences looks differently. In the model with only first-order lagged explanatory variables (column 2 of Table 4.4) there are two positive adjustments. Even though individually these two effects are insignificant, the sum of the effects is positive and significant at the 10-percent level $(\mathrm{p}$-value $=0.08)$. When considering the model with an additional set of lags, the second order lagged $h s$-term is significant, yielding positive and significant total effect $(\mathrm{p}$-value $=0.07)$.

We illustrate the estimated dynamic and asymmetric effects from the preferred specification (column 3 of Table 4.4) of $h s$ on $h p$ in Figure 4.4. Panel (a) plots the estimated dynamic adjustment for a shortening of the standard workweek, and illustrates the overshooting of the contemporaneous effect. Similarly, Panel (b) presents the results of a comparable exercise for a prolongation of the standard workweek.

\subsection{Robustness}

The results presented in the previous section can arguably have sources other than the changes in the standard workweek length. We consider three potential issues, including selectivity, and show that these issues do not drive the presented results.

\subsubsection{Changes in the standard workweek and the unemployment rate}

The reductions in the standard workweek became effective in a period marked by falling unemployment rates, whereas the extensions became effective in a period of rising unemployment. One could argue that the changes in the stated preferences we observe are related to, or explained by, job insecurity. Job insecurity or the fear of being fired might trigger the desire for precautionary savings. However, we acknowledge that such an impact is not that plausible, as civil servants cannot be fired in principle, and job security for public sector employees is high as well.

The results presented in Table 4.5 indicate that effect sizes are smaller than in the standard model, but are still significant at the 10-percent level for the model without lags and the model with one lag. For the model with two lags the total effects are not significant at the 10 -percent level $(\mathrm{p}$-value $=0.14$ and $\mathrm{p}$-value $=0.16$, 
4 The impact of changes in the standard workweek on preferences for labor supply

respectively). Note, however, that the contemporaneous effect for the reductions and the second-order lagged effect for the extensions are still significant at the 5percent level. The insignificance of the total effects is due to adding insignificant regressors.

\subsubsection{Selectivity: Leaving the civil service after workweek extension?}

Especially when considering extensions in the standard workweek one might argue that the results presented in the previous section could be due to those individuals who are willing to experience an extension in the standard working time. Civil servants who are unwilling to undergo such 'treatment' select themselves out of the civil service. To check this potential problem we investigate the behavior of civil servants in the years 1993-2008, the years in which extensions in the standard working time took effect.

Exploiting the panel dimension of the SOEP, we create a variable that indicates whether or not an individual left the civil-servant status during a particular year. Throughout the 1993-2008 period only a minority of the civil servants, on average about 13.5 percent each year, left the civil service. ${ }^{15}$ We regress this indicator on the length of the standard workweek in the next year. This analysis essentially answers the question of whether an extension of the standard working time in the coming year is related to a higher probability of leaving the civil service. The results of a fixed-effects logit model indicate that the effect of an extension of the standard workweek is not related to leaving the civil service for civil servants during the year prior to that change ( $\mathrm{p}$-value $>0.1$ ).

\subsubsection{Wage endogeneity}

An issue left unaddressed up to this point is the endogeneity of the wage rate. The wage rate can be endogenous for several reasons, like measurement error, reverse causality and omitted variables. A common approach to tackle the endogeneityproblem is to employ instrumental variable estimation. A huge body of literature is concerned with identifying the effects of wage changes on changes in hours worked. Identification in that strand of the literature usually relies on a natural experiment, like changes in the marginal tax rate (e.g., Ashenfelter et al., 2010; Blundell et al., 1998; Bosch and Van Der Klaauw, 2012). Because identifying the true effect of wages on preferred hours is not the aim of the current study, and because of lack of an appropriate instrument, we approach the problem in a pragmatic way without employing instrumental-variable techniques. We instead use simulation techniques

\footnotetext{
${ }^{15}$ The minimum and maximum are 8.8 percent (1993 and 1996) and 15.6 percent (2002) respectively.
} 
to map out the sensitivity of the effect of changes in the standard working hours on preferred working hours to plausible values of the elasticity of labor supply. ${ }^{16}$ That is, we analyze how sensitive the estimated coefficient of the length of the standard workweek is to changes in the elasticity of labor supply.

When estimating Model 4.1, the long-run elasticity of labor supply $(\eta)$ is given by $\eta=\frac{\beta_{\text {wage }}}{\widehat{h p}}$, where $\beta_{\text {wage }}$ is the coefficient of the wage rate in Model 4.1 and $\widehat{h p}$ is the overall average of preferred hours in the sample. We start by estimating the standard model without lagged values and fixing the coefficient at several plausible values for the elasticity of labor supply, $\eta$. We rely on the work of Evers et al. (2008) to select the range of elasticities. Evers et al. (2008) perform a meta-analysis of uncompensated labor supply elasticities. The authors gathered 107 elasticity estimates (for males) from 19 different studies, not relying on OLS for identification, and reported elasticities in the range $[-0.24 ; 0.45] .{ }^{17}$ Only one study on German data was included (Bonin et al., 2003), which found an elasticity of 0.02 for men and 0.03 for women. This compares to an elasticity of $\eta=\frac{-2.59}{38}=-0.07$ found in our estimations.

We proceed as follows. For each possible elasticity between -0.25 and +0.45 (with 0.05 -increments), we calculate the associated coefficient $\beta_{\text {wage }}$ and estimate Model 4.1 fixing the wage coefficient at this level. In case of an elasticity of, for example, $\eta=0.15$, this means that we fix the coefficient $\beta_{\text {wage }}$ at $\eta \times \widehat{h p} \approx 0.15 \times 38=5.7$, and estimate the other parameters of the model accordingly. We find that even if the true elasticity is $\eta=-0.25$, which is more than three times the size of the elasticity we find, the aforementioned coefficient estimates are significant at the 5-percent level for reductions $(\mathrm{p}$-value $=0.02)$ as well as for extensions $(\mathrm{p}$-value $=0.02)$. For all elasticities above -0.25 both coefficients of interest are always significant at the 1-percent level and lie roughly between 0.2 and 0.7 .

From this exercise we can conclude that - for any reasonable value of the elasticity of labor supply - there is a significant positive effect of the length of the standard workweek on preferred hours per week. If anything, our $\hat{\beta}_{\text {wage }}$ might be underestimated because of reverse causality running from $h p$ to the wage rate. ${ }^{18}$

\footnotetext{
${ }^{16}$ We experimented with one instrumental variable in the standard model; the average wage rate in a certain reference group. Results remained quantitatively similar, but were just insignificant when allowing for asymmetric dynamic adjustments. Once including lags, instruments were too weak. Indeed, it is debatable to what extent the average wage rate in a reference group is a suitable instrument. In particular, it is questionable to what extent the exclusion restriction holds. A proper instrument does not have a direct influence on the dependent variable. In this case an increase in the average wage of a reference category could increase consumption in the reference category, which might in turn increase preferred consumption of other individuals, leading to higher preferred hours.

${ }^{17}$ Note that a recent and accurate estimate of -0.2 (Ashenfelter et al., 2010) is also included in this range.

${ }^{18} \mathrm{An}$ increase in preferred hours may lead to an increase in contractual and actual hours, and might therefore reduce the average wage rate.
} 
4 The impact of changes in the standard workweek on preferences for labor supply

Table 4.5: Results from standard model including the unemployment rate

\begin{tabular}{lccc}
\hline & $(1)$ & $(2)$ & $(3)$ \\
Dependent variable: & $h p$ & $h p$ & $h p$ \\
\hline$h s_{t} \times \mathbf{1}($ year $\leq \mathbf{1 9 9 3})$ & $0.23^{* *}$ & $0.70^{* *}$ & $0.63^{* *}$ \\
& $(0.11)$ & $(0.30)$ & $(0.32)$ \\
$h s_{t-1} \times \mathbf{1}($ year $\leq \mathbf{1 9 9 3})$ & & -0.43 & -0.27 \\
& & $(0.29)$ & $(0.37)$ \\
$h s_{t-2} \times \mathbf{1}($ year $\leq \mathbf{1 9 9 3 )}$ & & & -0.12 \\
& & & $(0.31)$ \\
$h s \times \mathbf{1}($ year $>\mathbf{1 9 9 3 )}$ & $0.22^{*}$ & 0.18 & 0.01 \\
& $(0.11)$ & $(0.16)$ & $(0.17)$ \\
$h s_{t-1} \times \mathbf{1}($ year $>\mathbf{1 9 9 3})$ & & 0.08 & -0.08 \\
& & $(0.15)$ & $(0.16)$ \\
$h s_{t-2} \times \mathbf{1}($ year $>\mathbf{1 9 9 3})$ & & & $0.31^{* *}$ \\
& & & $(0.15)$ \\
\hline Number of observations & 16,645 & 11,602 & 8,471 \\
Number of individuals & 3,813 & 2,660 & 1,909 \\
$\sum h s$-terms pre-1993 & $0.23^{* *}$ & $0.27^{*}$ & 0.24 \\
$\sum h s$-terms post-1993 & $0.22^{*}$ & $0.26^{*}$ & 0.23 \\
H0: all lags in model equal zero (p-value) & - & 0.12 & 0.02 \\
\hline
\end{tabular}

Note: Results for the standard model including state-specific unemployment rate. Robust standard errors are reported in parentheses. The asterisks $* * *, * *$ and * indicate significance at the 1-, 5- and 10-percent level. Only the variables of interest to our analysis are presented.

\subsection{Discussion of results: Reference effects}

The question remains what channels could explain the effects uncovered in this study. As briefly outlined above, there are at least four mechanisms that could account for the effects found in this study. These mechanisms will be discussed in turn.

First, habit-formation models can be viewed as reference-effects models in which preferences depend on past behavior and in which past behavior acts as a reference point. Habit formation models originate from the theory of consumer behavior, ${ }^{19}$ but the concept has been introduced in labor supply as well.

Models of habit formation typically explain current preferences and/or behavior by past behavior of the individual. Bover (1991) models the disutility of hours worked by $\left(h_{i t}-\alpha h_{i, t-1}\right)$, where $h_{i t}$ measures the number of hours worked by individual

\footnotetext{
${ }^{19}$ See the work of Duesenberry (1949). Pollak (1970), amongst others, formalized this concept and proposes that utility derived from a certain level of consumption of a good depends on the "necessary" (p.749) quantity - either psychologically or physiologically - of that good, which in turn could depend on past consumption. Campbell and Deaton (1989) and Fuhrer (2000) showed that consumers adjust consumption slower following changes in lifetime resources than is explained by the permanent income hypothesis (Friedman, 1957; Hall, 1978). Abel (1990), Constantinides (1990) and Jermann (1998) concluded that habit formation can explain the equity premium puzzle as identified by Mehra and Prescott (1985). Carroll et al. (2000) found that the fact that a higher growth rate leads to more savings can be reconciled with the theory if one allows for habit formation in consumption. See also the discussion in Frederick et al. (2002).
} 
$i$ in period $t$. The parameter $\alpha$ measures the strength of the habit-persistence mechanism. All else equal, higher labor supply in the past leads to stronger preferences for work through a reduction in the disutility of working. The results found in the current study could potentially be explained by a habit-formation mechanism, as a change in the standard working time affects actual working hours. The subsequent change in behavior, working longer or shorter hours, would induce a change in reported preferred hours in the same direction. ${ }^{20}$

The evidence in favor of habit formation in labor supply models is not overwhelming. Johnson and Pencavel (1984) investigated the dependence of current on past hours worked as well, but did not take into account the correlation between the lagged dependent variable - the independent variable of interest - and the error term. Bover (1991) did take into account the correlation between the lagged dependent variable and the error term and found a significant effect of past on current hours, but the exogeneity of the instrument set was not questioned. Moreover, she does not have information on preferred hours. Woittiez and Kapteyn (1998) estimated the effect of past working hours on current preferred hours and find an economically and statistically significant positive effect. However, the authors were unable to control for unobserved heterogeneity as they only have two years of data.

The second possible channel through which preferences could be affected by the change in the standard working time is preference interdependence. If preferences with respect to labor supply depend on behavior of a certain reference group, preferences might not change because one's own behavior changes (i.e. habit formation), but because the observed behavior of colleagues changes. ${ }^{21}$ Even if someone in first instance does not want to work longer hours after a workweek extension, preferred hours may yet adjust upward because the colleagues are observed to work longer hours. If that is the case, preferences for hours worked might depend on a function of the hours worked by colleagues, or another reference group (Blomquist, 1993). This channel is comparable to the spillover effect described in Grodner and Kniesner (2006). In case of the spillover (or social-utility) effect, the utility function includes an interaction between the decision variable, $h$ in case of Grodner and Kniesner, and the average number of hours worked in a certain reference group. As a result, preferences for working longer hours are stronger if the average hours worked in the reference group is high.

Third, the standard workweek itself may act as a social norm which individuals internalize in their utility function. An example would be the conformity effect analyzed by Grodner and Kniesner (2006). In their model the extent to which someone deviates from a social norm yields disutility, on top of the disutility of hours worked that is commonly assumed (see also Vendrik, 2003). A plausible social norm is the standard working time itself, at least for full-time workers. Changes in

\footnotetext{
${ }^{20}$ See Vendrik (1993) for a theoretical model of habit formation.

${ }^{21}$ Weinberg et al. (2004) found that neighborhood characteristics affect individual hours worked. Maurin and Moschion (2009) found that mothers are more likely to participate on the labor market if other mothers in the neighborhood also participate.
} 
$\underline{4 \text { The impact of changes in the standard workweek on preferences for labor supply }}$

the standard workweek then imply that the social norm some people would like to adhere to alters. Therefore, a change in the length of the standard workweek could affect preferred working hours.

The fourth possible explanation for an effect of standard hours on preferred hours is anchoring in answering behavior. A plausible anchor in our case is the length of the standard workweek, as it is a potentially salient reference point. A change in this anchor could change stated preferences into the same direction. Tversky and Kahneman (1974) show how an arbitrary reference point can affect individual decision making. The length of the standard workweek should in principle be arbitrary with respect to working time preferences. That is, in the standard model it does not affect the optimum of preferred hours.

Given that the data we have at our disposal is not experimental in nature, we are unable to pin down the exact mechanism(s) that account(s) for the effects we detected in our analysis. Rather, the study presents evidence that a change in the standard working time affects preferred working hours, which in turn suggests that reference effects like the ones discussed above $d o$ influence working time preferences.

\subsection{Summary and concluding remarks}

In this study we have investigated to what extent preferred working hours are subject to reference effects by estimating the effect of a change in standard working time on preferences for labor supply of West-German civil servants and public sector employees. The results indicate that the length of the standard workweek has a positive and statistically significant long-term effect on the preferred weekly working hours. The effect is economically significant as well. Our estimates of the long-term effect suggest that a one-hour reduction/extension in the standard weekly working hours leads to about a twenty-minute drop/increase in the preferred working time.

Even though the long-term effect on standard working time on preferred hours is similar for extensions and reductions in the standard workweek, the estimates show that the dynamic adjustment of preferences following a prolongation of the standard workweek is different from the adjustment following a cut. We find that individuals subject to an expansion of standard hours slowly adjust their preferred hours upwards over the two-year period following the change. When confronted with a reduction of standard working hours, preferred hours dropped immediately by almost as many hours as the reduction was. However, in the two years after the reduction, preferences partly reverted back to the old level. The initial response is almost three times as high as the long-term response. This finding indicates that individuals preferences are affected differently by 'good' and 'bad' changes. ${ }^{22}$

\footnotetext{
${ }^{22}$ Di Tella et al. (2010) found that the level of reported happiness reacts differently (in the short term) to positive and negative shocks in income. However, the effect is economically small.
} 
The fact that the current length of the standard workweek has a strong effect on individual preferences is especially interesting in light of the standard habit formation literature. The habit formation literature usually attempts to identify the effect of past behavior on current behavior or preferences. When working with survey data, the 'past' is usually about a year ago. Indeed, when we estimate the classical labor supply model without a contemporaneous $h s$-term term and without allowing for any asymmetries (i.e. removing the contemporaneous term in column 2 of Table 4.3$)$, we find that $h s_{t-1}$ has a positive and significant effect on preferred hours $(0.38 ;$ p-value $<0.01)$. This may be interpreted as habit formation. Yet, once we control for current standard hours (column 2 of Table 4.3), the effect of the lagged term vanishes. 


\section{Interdependent preferences in labor supply ${ }^{1}$}

\section{$5.1 \quad$ Introduction}

Over the past 25 years people working in the German public sector experienced several changes in the length of their standard workweek. In Chapter 4, we documented that these changes affected individual preferences for work and leisure. However, the analysis in the previous chapter leaves open through which channel, or channels, preferences are shaped. ${ }^{2}$ One of the potential channels is preference interdependence with respect to hours worked. That is, individuals may prefer to work longer hours following an increase in the standard workweek because they observe their co-workers working longer hours. ${ }^{3}$ In this chapter we attempt to empirically isolate the effect of co-workers' labor supply decisions on individual labor supply preferences.

Interdependent preferences in labor supply are of interest to policymakers since changes in policy variables may not only have a direct effect on the target group, but can also change the preferences of individuals who are not directly affected by

\footnotetext{
${ }^{1}$ I thank my supervisors Thomas Dohmen and Maarten Vendrik for extensive discussions and indepth advice they gave my while writing this chapter (paper in progress). I also thank participants at the Nederlandse ArbeidsmarktDag (The Hague, 2013) for their comments. The data used in this study were extracted using the add-on-package PanelWhiz for Stata. See Haisken-DeNew and Hahn (2006) for details.

${ }^{2}$ That is, for individuals who face a change in the standard working hours it is difficult to disentangle the different effects.

${ }^{3}$ The idea that imitative behavior affects decision making has been voiced earlier in the theoretical literature (e.g., Blomquist, 1993).
} 
the policy. For example, a policy that affects labor supply decisions of individual $i$, might influence the preferences for work and leisure of $i$ 's colleague $j$ who is not directly affected by the policy. In this study, we aim to identify whether such spillover effects of policy exist because of interdependent preferences.

We assume that preferred working time depends on the actual hours worked by colleagues, which seems to be a plausible assumption (cf. Mayraz et al. (2009) and Clark and Senik (2010) for the case of income comparisons). We identify the effect of co-workers' hours on individual preferences by relying on the particular composition of the workforce in the German public sector, which consists of public sector employees and civil servants. These two types of workers are often co-workers and may even perform the same tasks. Between 1993 and 2005 civil servants (Beamte) experienced several prolongations of the standard workweek, changing the hours they worked (see Chapter 4). We assess empirically whether these changes affected the preferred working hours of public sector employees (Angestellte im öffentlichen Dienst), whose standard workweek was not prolonged.

We find that the changes in the working hours of civil servants significantly affect the preferences for labor supply of public sector employees. Our estimates indicate that a one-hour increase in average hours worked by civil servants induced a preference among public sector employees for working about two-thirds of an hour more per week. As the analysis below casts some doubt on the exclusion restriction of the instrumental variable, we also estimate a reduced-form model. In this reducedform estimation we find that a one-hour increase in the standard workweek of civil servants leads to a quarter of an hours increase in the preferred working time of public sector employees.

The rest of the paper is structured as follows. In Section 5.2 we first discuss the literature that is closely related to the current study. In Section 5.3 we analyze the concept of preference interdependence in more detail and elaborate on how it is identified. In Section 5.4 the data are presented, after which the results are presented in Section 5.5. In Section 5.6 we discuss the validity of the exclusion restriction of the instrumental variable. Section 5.7 discusses the results and concludes.

\subsection{Literature}

A considerable body of literature has been devoted to the analysis of interdependent preferences in labor supply. In this section we give a brief overview of the literature that is most related to our study. The idea of preference interdependence originates from the consumption literature (e.g., Duesenberry (1949)). In this strand of the literature it is argued that current preferences for consumption depend on other 
people's consumption patterns. ${ }^{4}$ Clearly, changes in preferences for consumption can affect labor supply decisions, as individuals trade-off leisure and consumption. Apart from this indirect effect of preference interdependence on labor supply, a different strand of literature considers how the labor supply decisions of others affect an individual's preferences for work and leisure.

Blomquist (1993) and Vendrik (1998) developed theoretical models in which an individual's working hours depend on the average number of hours worked in a particular reference group. Blomquist (1993) argues that models that neglect this effect cannot accurately predict the effects of a tax change on labor supply; and Vendrik (1998) provides an explanation for the growth in female labor force participation. Grodner and Kniesner (2006) theoretically investigated the effects of spillover and conformity in a model of labor supply. The authors conclude that the neglect of endogenous social interactions leads to biases in the estimation of the elasticity of labor supply.

Maurin and Moschion (2009) empirically investigated labor force participation along the extensive margin and found that mothers who live in a neighborhood with many working mothers are more likely to work themselves. Similarly, Weinberg et al. (2004) showed that the number of actual hours worked is related to neighborhood characteristics, like the employment rate of adult men. In line with that, Grodner and Kniesner (2008) found that hours worked by individuals are related to those worked by an economically and geographically close reference group. It is not clear, however, whether this correlation is the result of a causal impact of such reference groups on individuals' labor supply decisions. In fact, their estimates imply unreasonably large effects, which only become plausible when a lag of individual hours worked is included in the regression. ${ }^{5}$ Woittiez and Kapteyn (1998) incorporated survey information on reference groups and estimated a standard labor supply model. The authors concluded that preference interdependence contributes significantly to explaining preferences for labor supply. However, when allowing for habit formation, by controlling for lagged hours worked, the preferenceinterdependence effect is insignificant. Moreover, the authors are unable to allow for individual heterogeneity.

\subsection{Identification of interdependent preferences}

In this chapter we attempt to identify the effect of the hours worked by co-workers on the stated preferences for hours worked of individuals $(h p)$. We assume that the

\footnotetext{
${ }^{4}$ In the model of Pollak (1976) and Kapteyn (1977) the parameters of the utility function vary with other people's consumption patterns.

${ }^{5}$ As the lagged dependent variable is not instrumented (see also Bover, 1991), and since the authors do not control for unobserved heterogeneity, it is likely that the results represent correlations rather than causal effects. A potential alternative explanation of the results could be the heterogeneity in economic activity across regions, which is not controlled for by the authors.
} 
preferred working hours of individual $i$ generally depend on the hours worked by all members $j \neq i$ of a reference group $\mathbf{r}_{i}$, as well as a vector $\mathbf{x}_{\mathbf{i t}}$, which captures (other) observable determinants of labor supply, and an unobserved individualspecific effect.

$$
h p_{i t}=\beta_{0} f\left(\left\{h_{j t} \mid j \in \mathbf{r}_{i}\right\}\right)+\boldsymbol{\beta}^{\prime} \mathbf{x}_{\mathbf{i t}}+\epsilon_{i t} .
$$

It is common to assume that the term $f\left(\left\{h_{j t} \mid j \in \mathbf{r}_{i}\right\}\right)$ equals the average hours worked in the reference group, $\bar{h}_{\mathbf{r}_{i}} \cdot{ }^{6}$ Variation in this average only identifies preference interdependence if it is not driven by factors that also directly affect $h p_{i t}$. For example, a sudden increase in the workload that causes an increase in hours worked across the board might also have a direct effect on everybody's preferred hours (e.g., through habit formation), and would hence introduce a spurious correlation between average hours and individual preferred hours. ${ }^{7}$

To solve this problem we exploit the fact that the German public sector employs two different types of workers: civil servants who faced extensions in their standard workweek during 1993-2005 and public sector employees whose standard workweek remained unchanged at 38.5 hours. We investigate whether changes in the average working hours of civil servants that were induced by changes in their standard workweek, affected the preferences of public sector employees in a particular state and year. These workweek extensions were introduced to reduce labor costs in the longer term and did not seem to be directly related to a sudden economic shock that might have affected individual desired hours as well. ${ }^{8}$

We operationalize $\bar{h}_{\mathbf{r}_{i}}$ by the average hours worked by civil servants in a particular state and year $\left(\bar{h}_{C S}\right)$, and instrument this average with the standard workweek maintained in that particular state and year. Under the maintained assumption that the changes in the standard workweek of civil servants did not directly affect the working time preferences of public sector employees, this approach identifies preference interdependence.

Figure 5.1 shows that civil servants working at the state level experienced several changes in the standard workweek. The standard workweek of civil servants working at the federal level evolved differently. ${ }^{9}$ The latter group saw one single increase in standard hours from 38.5 to 40 in October 2004. Unfortunately, we do not know whether public sector employees work at the state or at the federal level.

\footnotetext{
${ }^{6}$ See, for example, the overview of the social-comparison literature by Clark et al. (2008).

${ }^{7}$ This is a subtle variant of the 'reflection problem' as discussed by Manski (1993).

${ }^{8}$ This reason is stated in an email received from one of the state ministries: "...hatte die Verlängerung der Wochenarbeitszeit ... haushalterische Gründe. Bei gleichbleibendem Einkommen standen insgesamt mehr Arbeitsstunden zur Verfügung. Dieser Arbeitszeitgewinn für den Dienstherrn konnte (allerdings auf längere Sicht) für Personaleinsparungen in Höhe des Arbeitszeit-Gegenwertes genutzt werden."

${ }^{9}$ For an elaborate discussion about the assignment to the standard-hours regimes, see Section 4.3 .
} 
Consequently, we do not know whether their colleagues work at the state level (Landesbeamte) or at the federal level (Bundesbeamte). We treat our data as if all employees and civil servants are employed at the state level, implying that the relevant reference group $\left(\mathbf{r}_{i}\right.$ in $\left.\bar{h}_{\mathbf{r}_{i}}\right)$ are all the civil servants in the same state and year. This probably leads to an underestimate of the true effect.

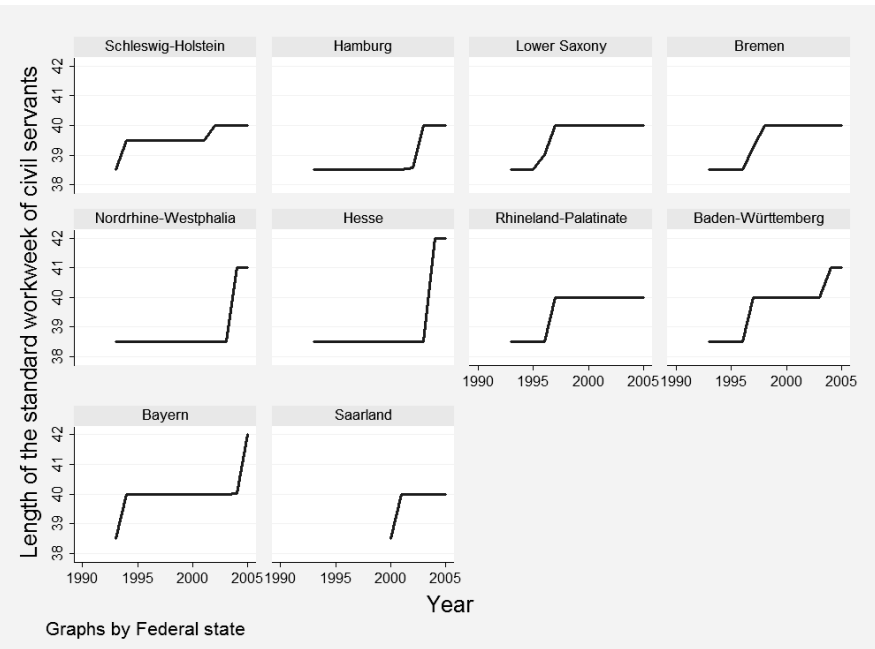

Figure 5.1: Length of the standard workweek for civil servants in WestGerman federal states.

Note: This figure shows the length of the standard workweek for civil servants for all West-German federal states. Note that before 2000 the SOEP does not discriminate between individuals living in Saarland and RhinelandPalatinate. Source: Federal Ministry of the Interior. The documents used to construct this figure are available from the authors upon request.

\subsection{Data}

The data used in this paper come from the German Socio-Economic Panel Study (SOEP), waves 1993 to $2005 .^{10}$ The sample is restricted to employees in the public sector who are between the ages of 15 and 59 (inclusive). We exclude all individuals in full-time education, individuals with an additional job, and those who reported (preferred) hours of more than 84 per week (seven times half a natural day). Finally, we should note that before the year 2000, we are unable to discriminate between individuals living in Saarland and Rhineland-Palatinate. Since the inhabitants of Saarland constitute only a minor fraction of the sample, we neglect this issue.

The dependent variable in the analyses below is the preferred hours worked per

\footnotetext{
${ }^{10}$ The data were extracted using the add-on-package PanelWhiz for Stata. See Haisken-DeNew and Hahn (2006) for details.
} 


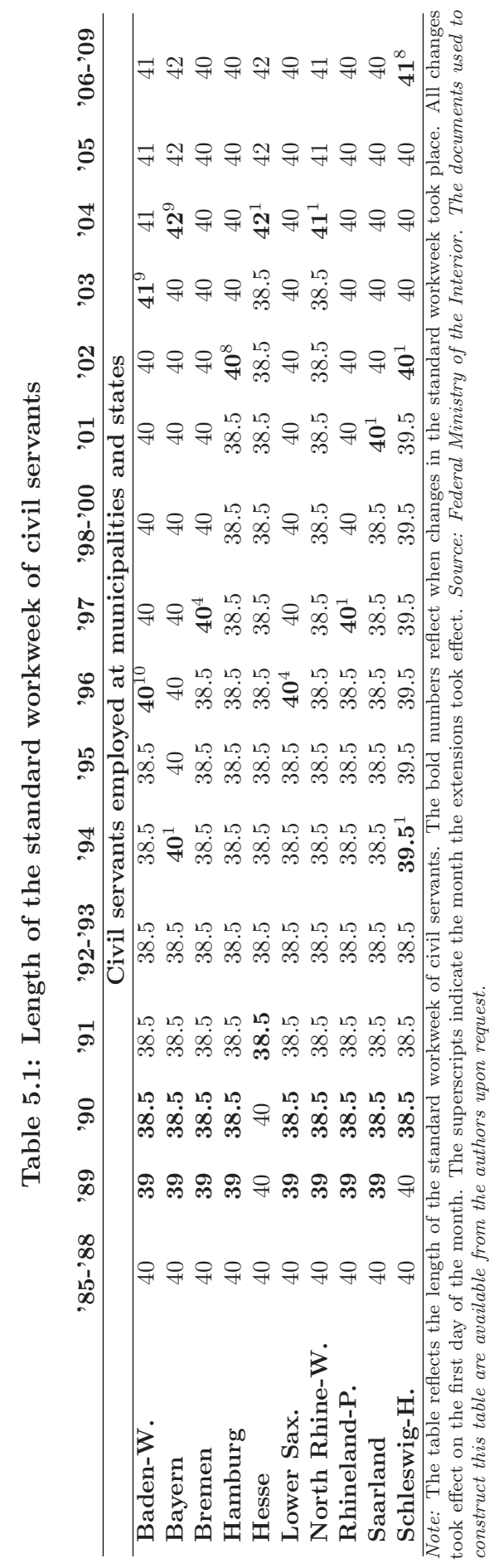


week (denoted $h p$ ), which is available in all waves, except for $1996 .{ }^{11}$ Respondents were asked the following question: "If you could choose your own number of working hours, taking into account that your income would change according to the number of hours: How many hours would you want to work?". ${ }^{12}$ We assume that individuals answer the question with their contractual hourly wage in mind. ${ }^{13}$

In this study we estimate the effect of average hours worked by civil servants on preferences for labor supply of public sector employees. These average hours are computed for each year and state using the following variable in the SOEP: "And how many hours do your actual working hours consist of including possible overtime?". ${ }^{14}$ The source of variation in the average hours of civil servants that we exploit in this study is changes in the standard workweek of civil servants. These changes are presented in Table 5.1. We received information on the length of the standard workweek of civil servants from the Federal Ministry of the Interior.

\subsection{Results}

In column (1) of Table 5.2 we present the parameter estimates of an instrumental variable (IV) estimation of model 5.1. We instrument the average hours worked by civil servants with their standard workweek. The results indicate that the average hours worked by civil servants significantly and positively affect the working time preferences of public sector employees. A one-hour increase in average hours of civil servants increases the preferred working hours of public sector employees by about two-thirds of an hour (s.e. $=0.25$; p-value $<0.01) .{ }^{15}$

The first-stage regression results are presented in column (2). The KleibergenPaap F-statistic in column (2) indicates that the estimates do not suffer from the weak-instrument problem, as it is well above 10 .

Even though the focus in column (1) is on average hours worked by civil servants $\left(\bar{h}_{C S}\right)$, preferences of public sector employees $h p$ can potentially be affected by the average hours worked of other public sector employees $\left(\bar{h}_{P S E}\right)$ as well. Yet, if

\footnotetext{
${ }^{11}$ One might be skeptical to draw conclusions from subjective data of the kind presented here. However, Euwals et al. (1998) showed that, in addition to qualitative information, using desired hours helps to predict future actual hours.

${ }^{12}$ In the German version of the questionnaire, the question was phrased as follows: "Wenn Sie den Umfang Ihrer Arbeitszeit selbst wählen könnten und dabei berücksichtigen, daß sich Ihr Verdienst entsprechend der Arbeitszeit ändern würde: Wie viele Stunden in der Woche würden Sie dann am liebsten arbeiten?"

${ }^{13}$ We calculate the contractual hourly wage as $\frac{Y_{L}}{h c * \times 4 \frac{1}{3}}$, where $Y_{L}$ and $h c$ represent monthly individual labor earnings and contractual weekly working hours, respectively.

${ }^{14}$ The original, German, phrasing of the question read as follows: "Und wieviel beträgt im Durchschnitt Ihre tatsächliche Arbeitszeit einschließlich eventueller Überstunden?"

${ }^{15} \mathrm{In}$ unreported results we did not find any evidence for dynamic/lagged effects of the average hours worked on individual preferences. In these results we followed the same approach as in the previous chapter.
} 
preference-interdependence effects are at play, $\bar{h}_{P S E}$ can be considered a mediating variable for the effect of $\bar{h}_{C S}$ on $h p$, and hence a bad control (in the sense of Angrist and Pischke (2008)), and should therefore not be included as an explanatory variable in column (1). Consider the prolongations in the standard workweek of civil servants that raise their average working hours. If such increases positively impact the preferred hours of public sector employees, they may adjust working hours accordingly. Indeed, in an IV regression similar to the one presented in column (1) of Table 5.2 we find that the average hours of civil servants, instrumented by the length of their standard workweek, has a positive effect on the average hours of public sector employees $(0.57$; s.e. $=0.05$; p-value $<0.01)$. We therefore exclude the average $\bar{h}_{P S E}$ from the regression in column (1). Consequently, the total effect of 0.67 presented in column (1) of Table 5.2 reflects the total preferenceinterdependence impact of a direct effect of a change in $\bar{h}_{C S}$ on $h p$ as well as an indirect effect of that change in $\bar{h}_{C S}$ through $\bar{h}_{P S E}$ on $h p$.

\subsection{Validity of the exclusion restriction of the instrumental variable}

In the above IV specification we maintain the assumption that the standard workweek of civil servants does not have a direct effect on the preferred working time of public sector employees. That is, the standard workweek should fulfill the exclusion restriction for instrumental variables. We now investigate how the previous result changes once we relax this assumption. Relaxing the exclusion restriction implies that we allow the standard workweek of civil servants to have a direct effect on preferred hours of public sector employees, rather than only through the average hours worked by civil servants. A positive effect of the standard workweek of civil servants on the preferred hours of public sector employees casts doubt on whether the standard workweek is a suitable instrument in this analysis.

The results from a fixed-effects OLS regression in column (3) of Table 5.2 indicate that changes in the standard workweek of civil servants have a marginally significant $(\mathrm{p}$-value $=0.07)$ direct effect on the preferred working time of public sector employees. The effect of the average hours worked by civil servants is comparable in size but significant even at the 5-percent level. It indicates that a one-hour increase in the average hours worked by civil servants increases the preferred hours of public sector employees by about one-fifth of an hour. However, this OLS estimate of average hours $(0.19$; s.e. $=0.08)$ is not significantly different from the coefficient of average hours in the IV regression $(0.67$; s.e. $=0.25)$ in column $(1)$. The result that $h s_{C S}$ has a significant impact on $h p$ suggests the exclusion restriction is not satisfied. However, this combination of results from the OLS regression should be interpreted with some caution for at least two reasons.

On the one hand, approximating the average hours worked in the true reference 
Table 5.2: Results

\begin{tabular}{|c|c|c|c|c|}
\hline Dependent variable: & $\begin{array}{l}\text { (1) } \\
h p\end{array}$ & $\begin{array}{c}(2) \\
\bar{h}_{C S}\end{array}$ & $\begin{array}{l}\text { (3) } \\
h p\end{array}$ & $\begin{array}{l}\text { (4) } \\
h p\end{array}$ \\
\hline \multirow[t]{2}{*}{ Average hours of civil servants $\left(h_{C S}\right)$} & $0.67^{* * *}$ & & $0.19^{* *}$ & \\
\hline & $(0.25)$ & & $(0.08)$ & \\
\hline \multirow[t]{2}{*}{ Standard workweek civil servants $\left(h s_{C S}\right)$} & & $0.39^{* * *}$ & $0.19^{*}$ & $0.26^{* * *}$ \\
\hline & & $(0.02)$ & $(0.10)$ & $(0.10)$ \\
\hline \multirow[t]{2}{*}{ Natural log of hourly wage } & $-2.39^{* * *}$ & $-0.19 * *$ & $-2.48^{* * *}$ & $-2.51 * * *$ \\
\hline & $(0.49)$ & $(0.08)$ & $(0.57)$ & $(0.57)$ \\
\hline \multirow[t]{2}{*}{ Other income, thousands per week } & $-2.49^{* * *}$ & -0.15 & $-2.56^{* * *}$ & $-2.59 * * *$ \\
\hline & $(0.45)$ & $(0.10)$ & $(0.53)$ & $(0.53)$ \\
\hline \multirow[t]{2}{*}{ Education unknown } & 0.73 & 0.04 & 0.75 & 0.76 \\
\hline & $(0.52)$ & $(0.15)$ & $(0.62)$ & $(0.62)$ \\
\hline \multirow[t]{2}{*}{ College education } & $3.89^{* * *}$ & -0.37 & $3.71^{* * *}$ & $3.64^{* * *}$ \\
\hline & $(0.98)$ & $(0.26)$ & $(1.36)$ & $(1.36)$ \\
\hline \multirow[t]{2}{*}{ Age $<35$} & -0.38 & -0.05 & -0.41 & -0.41 \\
\hline & $(0.36)$ & $(0.08)$ & $(0.40)$ & $(0.40)$ \\
\hline \multirow[t]{2}{*}{ Age $>44$} & 0.01 & 0.07 & 0.04 & 0.06 \\
\hline & $(0.32)$ & $(0.08)$ & $(0.36)$ & $(0.36)$ \\
\hline \multirow[t]{2}{*}{ Person lives with spouse } & $-1.62^{* * *}$ & 0.04 & $-1.61^{* * *}$ & $-1.60 * * *$ \\
\hline & $(0.39)$ & $(0.07)$ & $(0.44)$ & $(0.44)$ \\
\hline \multirow[t]{2}{*}{ Children under 16 in household (if 1) } & $-2.93^{* * *}$ & 0.06 & $-2.90 * * *$ & $-2.89^{* * *}$ \\
\hline & $(0.35)$ & $(0.07)$ & $(0.47)$ & $(0.48)$ \\
\hline \multirow[t]{2}{*}{ Trend } & 0.07 & -0.00 & 0.07 & 0.07 \\
\hline & $(0.05)$ & $(0.02)$ & $(0.07)$ & $(0.07)$ \\
\hline \multirow[t]{2}{*}{ Trend $\times 1[$ Female $]$} & $-0.23^{* * *}$ & -0.01 & $-0.23^{* * *}$ & $-0.23^{* * *}$ \\
\hline & $(0.06)$ & $(0.02)$ & $(0.07)$ & $(0.07)$ \\
\hline Number of observations & 8,462 & 8,462 & 8,462 & 8,462 \\
\hline Number of individuals & 2,490 & 2,490 & 2,490 & 2,490 \\
\hline Kleibergen-Paap F-statistic & - & 438 & - & - \\
\hline
\end{tabular}

Note: Column (1) presents the results of a fixed-effects instrumental variable regression of preferred hours of public sector employees on average hours worked of civil servants. Column (2) presents the corresponding first-stage regression results. Robust standard errors are presented between parentheses. Column (3) presents the results of a fixed-effects OLS regression of preferred hours on average working hours of civil servants, including the standard workweek of civil servants as an additional explanatory variable. Column (4) presents the reduced-form of the effect of the standard working time of civil servants on the preferred hours of public sector employees. Robust standard errors are presented in parentheses. The asterisks ***,** and * indicate significance at the 1-, 5-, and 10-percent level, respectively. 
group of civil servants by the average hours worked of civil servants living in the same state/year potentially inflicts a downward bias on the estimated coefficient $\left(\beta_{\bar{h}_{C S}}\right)$, because of random measurement error in $\bar{h}_{C S}$. This downward bias then inflicts an upward bias upon $\beta_{h s_{C S}}$. Such an upward bias in the estimate of $\beta_{h s_{C S}}$ indicates that the true effect of the standard workweek on preferred hours would be weaker than presented in column (3) of Table 5.2. A strong bias would then imply that the exclusion restriction might still hold.

On the other hand, as discussed in Section 5.3, the OLS coefficient of average hours worked $\left(\beta_{\bar{h}_{C S}}\right)$ may suffer from spurious correlation between $\bar{h}_{C S}$ and $h p$, which is likely to inflict a positive bias on $\beta_{\bar{h}_{C S}}$. If such a bias exists, the OLS coefficient might in fact be an overestimate of the (potentially insignificant) true effect. Because of the positive correlation between $\bar{h}_{C S}$ and $h s_{C S}$, the coefficient of the standard workweek in the OLS regression in column (3) of Table $5.2\left(\beta_{h s_{C S}}\right)$ is potentially biased towards zero. It would therefore be a lower-bound estimate, suggesting that the true $\beta_{h s_{C S}}$ is potentially stronger and more significant than presented here, falsifying the exclusion restriction maintained in the instrumental variable approach with more certainty.

If the exclusion restriction does not hold, changes in the standard workweek likely affect preferences through other channels than via average hours worked. ${ }^{16}$ Even though a direct effect of the excluded instrument on the dependent variable hampers the identification of the preference-interdependence effect as investigated up to this point (i.e. the effect of average hours on preferences), it is still interesting to estimate the reduced-form total effect of the change in the standard workweek $\left(h s_{C S}\right)$ on the preferences for work and leisure of the public sector employees. The results of this regression are presented in column (4) of Table 5.2. The estimate of $\beta_{h s_{C S}}$ suggests that a one-hour increase in the standard workweek of civil servants leads to a quarter of an hour increase in the preferred working time of public sector employees.

\subsection{Discussion and concluding remarks}

In this chapter we exploit the particular composition of the workforce in the German public sector in an attempt to identify the effect of average hours worked by coworkers on an individual's preferred number of hours worked. The workforce in the German public sector consists of two types of workers: public sector employees and civil servants. The particular feature of the German public sector is that these two types of workers are often co-workers and can even perform the same tasks. A difference between the two groups of workers is the length of the standard workweek. During the 1993-2005 period the standard hours of public sector employees remained

\footnotetext{
${ }^{16}$ As discussed in the previous chapter we argued that the standard working time an individual is subject to can act as a social norm individuals might want to adhere to. The standard workweek of civil servants might act as a similar social norm.
} 
constant at 38.5 hours per week, whereas the standard workweek of civil servants was lengthened from 38.5 hours in 1993 to 40-42 hours per week by the end of the sample period. These policy changes provide a quasi-experimental design that offers the opportunity to estimate the effect of changes in co-worker's working hours on individual preferences for work and leisure. To the best of our knowledge, this study is the first to exploit variation in the standard workweek in an attempt to identify preference interdependence.

We estimate a standard labor supply model in which we allow preferences for labor supply of a public sector employee to depend on the average hours worked of the civil servants in the same state/year. The average-hours variable in turn is instrumented using the length of the standard workweek. The results in Table 5.2 suggest that the changes in standard and average hours worked of civil servants significantly impacts the preferred hours of public sector employees. A one-hour increase in the average hours worked of civil-servants increases desired hours of public sector employees by about two-thirds of an hour.

Two points of discussion when employing instrumental variable techniques are the absence of spurious correlation between the instrument and the dependent variable, as well as the validity of the exclusion restriction of the instrument. With respect to the first point one usually relies on assumptions. In this study, changes in the instrument did not seem to be related to an economic shock that might have simultaneously affected the dependent variable in our analysis. With respect to the second point we performed an additional check. The results of this additional analysis, an OLS regression with the excluded instrument added as regressor, indicate that the exclusion restriction of the instrument may not hold. Since the coefficients estimated by this OLS regression might suffer from upward as well as downward biases, we also presented the results of a reduced-form estimation in which the preferred hours of public sector employees are regressed on the standard workweek of civil servants. These results suggest that a one-hour increase in the standard workweek of civil servants leads to a quarter of an hour increase in the preferred working time of public sector employees. This total effect may consist of a direct effect of the standard workweek on individual preferences, as well as the indirect effect of a change in the standard working time through the average hours of civil servants. 



\section{Conclusion and discussion}

In this thesis we investigate the heterogeneity in working time preferences and their formation. In this concluding chapter we summarize, discuss and reflect on the findings.

\subsection{Chapter 2}

The aim of Chapter 2 is twofold. First, it presents an overview of the heterogeneity in the desire to change weekly working hours by applying regression analysis techniques. Second, it incorporates the findings of this heterogeneity analysis and formulates an implication for policy aimed at increasing the working hours among working women in the Netherlands.

The results from the heterogeneity analysis indicate that there is a sizable group of part-time-working women who would like to increase their weekly working hours, mainly women who perform semi- or unskilled manual labor and women with lower education levels. At the same time, a large group of women would prefer to reduce their weekly working hours. This second group consists mainly of highly educated women.

The particular structure of the heterogeneity with respect to the discrepancy between actual and preferred hours suggests a fruitful route for policymakers who would like to induce women to work longer hours. We suggest that policy could be tailored towards those women who are already willing to work longer hours as 
their preferences do not need to be altered in order to facilitate an increase in hours worked.

If we target policy towards those already willing work more hours, how large of an effect on participation could we expect? The size of a potential increase is hard to quantify exactly. Yet, we find that about six percent of the 2010 -wave consists of working women with a lower level of educational attainment ${ }^{1}$ who would like to increase their working hours. An additional 1.5 percent of the sample performs manual work and prefers to increase their weekly working hours. These two groups together form over 7 percent of the sample and would prefer to increase their workweek by about 7 hours. Given the length of their current workweek of slightly more than 18 hours, this would represent a substantial increase in working hours for a substantial fraction of the sample.

\subsection{Chapter 3}

In Chapter 3 we explain the implication of heterogeneity in the desire to change weekly working hours from a different angle. Instead of putting the focus on heterogeneity between different groups of employees, we investigate the heterogeneity with respect to the desire to reduce working hours within groups of individuals sharing a comparable set of characteristics. Several previous studies show that there is a strong correlation between the number of hours worked and the desire to change weekly working hours. Namely, those who work longer hours are more likely to prefer a reduction in their weekly working hours, while those working only few hours per week are more likely to desire an increase. This implies that there is a point at which the probability of desiring a change in the weekly working hours is, on average, zero. Booth and Van Ours (2013) identified this point and named it the "equilibrium hours of work".

In the first part of the analysis of Chapter 3 we extend the approach of Booth and Van Ours and show that this equilibrium depends on individual characteristics. For example, semi- or unskilled manual workers aged 16-35 generally prefer to decrease their hours worked (on average) when they work about 32 hours or more. For nonmanual workers aged 55-59 the tendency to desire a reduction in weekly working hours sets in earlier, at about 16 hours per week. The fact that this point differs between groups with different background characteristics motivated the second part of the analysis.

In the second part of the analysis we investigate several groups of women with a particular combination of background characteristics and what fraction of each group works longer hours than the equilibrium hours of work belonging to that group. This fraction is an indication of how many women with a particular set of

\footnotetext{
${ }^{1}$ That is, either no education at all, primary education only, or a vmbo diploma.
} 
characteristics we expect to be willing to work shorter hours. This analysis provides useful insights for, for example, a supply-stimulating policy. If applied, a supplystimulating policy should primarily be focused on those who desire to reduce their weekly working hours for at least two reasons. First, the fact that employers like these women to work longer hours than they prefer to work suggests excess demand for workers with such characteristics. This is not the case for women who already prefer to work longer hours. ${ }^{2}$ Second, aligning preferred and actual working hours seems to be welfare-enhancing.

The results indicate, for example, that women who are working in business services relatively often (compared to those working in health care and welfare) work longer hours than the equilibrium belonging to women with their characteristics. Also, for highly educated women we find that they often work more hours than this 'equilibrium' and, therefore, we expect that the tendency to desire a reduction in the weekly working hours is stronger among this group. The heterogeneity uncovered here does not only provide policymakers with information on whom (or which groups) to target with supply-stimulating policy, but also gives them an hour range in which supply-stimulating policy may be fruitful.

In general, the results presented in Chapter 2 and Chapter 3 imply that the goal of a supply-stimulating policy should not be to increase the working hours of all working women in part-time jobs. ${ }^{3}$ Rather, the analyses show that there are groups of workers who already prefer to increase the number of hours they work. Stimulating the supply of labor, in terms of the preferred working hours, of these groups would be ineffective. To be successful, supply-stimulating and other policies should take into account the heterogeneity analyzed in Chapters 2 and 3.

\subsection{Chapter 4}

In Chapter 4 we turn to the question of whether working time preferences, as measured by self-reported preferred working hours, are subject to reference effects. Several theories, like preference interdependence and habit formation, point to the importance of reference effects in labor supply. We investigate whether preferences for work and leisure are affected by such reference effects. We exploit changes in the length of the standard workweek of (former) West German civil servants and public sector employees and investigate whether working time preferences change in response to reductions and extensions in the length of the standard workweek. In particular, we estimate a standard labor supply model in which we model an individual's preferred working hours of work as a function of conventional determinants of labor supply and augment this model with the length of the

\footnotetext{
${ }^{2}$ Rather, in order to increase hours worked in the latter group, one may consider policies stimulating the demand side of the market (Chapter 2).

${ }^{3}$ This was the goal of the Task Force Part-time Plus (Ministry of Social Affairs, 2008).
} 
standard workweek as an additional explanatory variable.

The results indicate that the variations in the standard workweek significantly and strongly changed the preferences with respect to weekly working hours. A reduction in the standard workweek was followed by a strong contemporaneous decrease in preferred hours. However, in the subsequent years preferences partly reverted towards the old level, such that the long-term effect was smaller than the short-term effect. A workweek extension led to a gradual increase in preferred weekly working hours over time. That is, we found an asymmetry in the adjustment process of preferred labor supply for extensions and reductions of standard hours.

Given that the data we have at our disposal are not experimental in nature, we were unable to pin down the exact mechanism or combination of mechanisms that account for the effects we detect in our analysis. Rather, we present evidence that a change in the standard working time affects preferred working hours, which in turn suggests that reference effects like the ones discussed above do influence working time preferences.

For future research it would be valuable to think about whether it is possible to identify these different reference effects (e.g. habit formation and preference interdependence) separately. And, if so, what kind of data would we need in order to identify these effects? That is, can we, for example, think of a source of exogenous variation in the actual hours worked that allows us to estimate the effect of individual behavior on individual preferences (habit formation), while guaranteeing that preference-interdependence effects are not in play? In Chapter 4 we cannot make this assumption as one of the potential channels through which the length of the standard workweek affects individual preferences is the labor supply behavior of others. Yet, in Chapter 5 we attempt to exclude habit formation as a potential explanation.

\subsection{Chapter 5}

As discussed, the analysis in Chapter 4 leaves open through which channel, or channels, working time preferences are shaped, following a change in the standard workweek. One of the potential channels through which this effect could work is preference interdependence with respect to hours worked. That is, individuals may prefer to work longer hours following an increase in the standard working time because they observe their co-workers working longer hours. In Chapter 5 we attempt to empirically isolate the effect of co-workers' labor supply decisions on the labor supply preferences of individuals, while ruling out the effect of own behavior (habit formation) as an explanation.

We model working time preferences as a function of conventional determinants of labor supply and, in addition, the average of actual hours worked by colleagues. 
To be able to identify the effect of the average hours worked by colleagues on individual preferences, we would ideally need a change in policy that affected the average hours worked by someone's colleagues, but that left this individual's own hours worked unchanged. In order to identify the effect of the hours worked by colleagues on individual preferences we therefore rely on the particular composition of the workforce in the German public sector, which consists of both public sector employees and civil servants. These two types of workers are often colleagues and may even perform the same tasks. Between 1993 and 2005 the standard workweek of civil servants experienced several prolongations which induced changes in average hours worked. Using the length of the standard workweek of civil servants as an instrument for the average hours worked by civil servants we assess empirically whether the resulting changes affect the stated preferences with respect to working time of their colleagues in the public sector who work as employees and whose standard hours did not change. The advantage of this approach is that the sudden change in the length of the standard working time of civil servants did not seem to be related to an economic shock that might have affected preferred working hours of public sector employees simultaneously.

Maintaining the assumption that the standard workweek of civil servants does not have a direct effect on the preferred working time of public sector employees (the exclusion restriction), the instrumental-variable estimation indicates that the average hours worked by civil servants significantly and positively affect the working time preferences of public sector employees. A one-hour increase in average hours of civil servants increases the preferred working hours of public sector employees by about two-thirds of an hour.

In order to investigate whether the exclusion restriction holds, we estimate an OLS regression in which we include the excluded instrument as an additional explanatory variable in the model. The coefficient of the length of the standard workweek of civil servants is marginally significant, casting doubt on the exclusion restriction on the instrumental variable. However, because of potential measurement error in the average hours worked by civil servants it is impossible to provide strong evidence against (or in favor of) the validity of the exclusion restriction of the instrumental variable. For the case that the exclusion restriction does not hold, we also presented the results of a reduced-form estimation in which the preferred hours of public sector employees are regressed on the standard workweek of civil servants. These results suggest that a one-hour increase in the standard workweek of civil servants leads to a fifteen-minute increase in the preferred working time of public sector employees. This total effect consists of a direct effect of the standard workweek on individual preferences, as well as the indirect effect of a change in the standard working hours through the average hours of civil servants. 



\section{Bibliography}

Abel, A. (1990). Asset prices under habit formation and catching up with the Joneses. American Economic Review, 80(2):38-42.

Angrist, J. and Evans, W. (1998). Children and their parents' labor supply: Evidence from exogenous variation in family size. American Economic Review, 88(3):450-477.

Angrist, J. and Pischke, J.-S. (2008). Mostly harmless econometrics. Princeton University Press.

Ashenfelter, O., Doran, K., and Schaller, B. (2010). A shred of credible evidence on the long-run elasticity of labour supply. Economica, 77(308):637-650.

Attanasio, O., Low, H., and Sánchez-Marcos, V. (2008). Explaining changes in female labor supply in a life-cycle model. American Economic Review, 98(4):1517-1552.

Barrett, G. and Doiron, D. (2001). Working part time: By choice or by constraint. Canadian Journal of Economics, 34(4):1042-1065.

Becker, G. (1971). Human Capital: A Theoretical and Empirical Analysis with Special Reference to Education. 2nd ed., New York: Columbia University Press.

Blomquist, S. (1993). Interdependent behavior and the effect of taxes. Journal of Public Economics, 51(2):211-218.

Blundell, R., Duncan, A., and Meghir, C. (1998). Estimating labor supply responses using tax reforms. Econometrica, 66(4):827-861.

Blundell, R. and MaCurdy, T. (1999). Handbook of Labor Economics; Labor Supply: A review of alternative approaches. Elsevier Science B.V.

Böheim, R. and Taylor, M. (2004). Actual and preferred working hours. British Journal of Industrial Relations, 42(1):149-166.

Bonin, H., Kempe, W., and Schneider, H. (2003). Household labor supply effects of low-wage subsidies in Germany. Journal of Applied Social Sciences Studies, 123(1):199-208.

Booth, A. and Van Ours, J. (2013). Part-time jobs: What women want? Journal of Population Economics, 26(1):263-283.

Bosch, N., Deelen, A., and Euwals, R. (2010). Is part-time employment here to 
stay? working hours of Dutch women over successive generations. Review of Labour Economics and Industrial Relations, 24(1):35-54.

Bosch, N. and Van Der Klaauw, B. (2012). Analyzing female labor supply: Evidence from a Dutch tax reform. Labour Economics, 19(3):271-280.

Bover, O. (1991). Relaxing intertemporal separability: A rational habits model of labor supply estimated from panel data. Journal of Labor Economics, 9(1):85100.

Campbell, J. and Deaton, A. (1989). Why is consumption so smooth? Review of Economic Studies, 56(3):357-373.

Carroll, C., Overland, J., and Weil, D. (2000). Saving and growth with habit formation. American Economic Review, 90(3):341-355.

Clark, A., Frijters, P., and Shields, M. (2008). Relative income, happiness, and utility: An explanation for the Easterlin Paradox and other puzzles. Journal of Economic Literature, 46(1):95-144.

Clark, A. and Senik, C. (2010). Who compares to whom? The anatomy of income comparisons in Europe. Economic Journal, 120(554):573-594.

Cloïn, M. (2010). Het werken waard. Het arbeidsaanbod van laagopgeleide vrouwen vanuit een economisch en sociologisch perspectief. $\mathrm{PhD}$ thesis, Utrecht University.

Constantinides, G. (1990). Habit formation: A resolution of the equity premium puzzle. Journal of Political Economy, 98(3):519-543.

Del Boca, D. and Vuri, D. (2007). The mismatch between employment and child care in Italy: the impact of rationing. Journal of Population Economics, 20(4):805832.

Di Tella, R., Haisken-De New, J., and MacCulloch, R. (2010). Happiness adaptation to income and to status in an individual panel. Journal of Economic Behavior and Organization, 76(3):834-852.

Duesenberry, J. (1949). Income, savings and the theory of consumer behavior. $\mathrm{PhD}$ thesis, Harvard University.

Euwals, R. (2001). Female labor supply, flexibility of working hours, and job mobility. Economic Journal, 111(471):C120-C134.

Euwals, R., Knoef, M., and Van Vuuren, D. (2011). The trend in female labor force participation: What can be expected for the future? Empirical Economics, 40(3):729-753.

Euwals, R., Melenberg, B., and Van Soest, A. (1998). Testing the predictive power of subjective labour supply data. Journal of Applied Econometrics, 13(5):567585.

Euwals, R. and Van Soest, A. (1999). Desired and actual labour supply of unmarried men and women in the Netherlands. Labour Economics, 6(1):95-118.

Evers, M., de Mooij, R., and Van Vuuren, D. (2008). The wage elasticity of labour supply: A synthesis of empirical estimates. De Economist, 156(1):25-43.

Fernández, R. (2013). Cultural change as learning: The evolution of female labor force participation over a century. American Economic Review, 103(1):472-500.

Fogli, A. and Veldkamp, L. (2011). Nature or nurture? learning and the geography of female labor force participation. Econometrica, 79(4):1103-1138. 
Bibliography

Fouarge, D. and Baaijens, C. (2003). Veranderende arbeidstijden. Slagen werknemers er in hun voorkeuren te realiseren? OSA Tilburg.

Frederick, S., Loewenstein, G., and O'Donoghue, T. (2002). Time discounting and time preference: A critical review. Journal of Economic Literature, 40(2):351401.

Friedman, M. (1957). A Theory of the Consumption Function. Princeton University Press.

Fuhrer, J. (2000). Habit formation in consumption and its implications for monetary-policy models. American Economic Review, 90(3):367-390.

Gregory, M. and Connolly, S. (2008). The price of reconciliation: Part-time work, families and women's satisfaction. Economic Journal, 118(526):F1-F7.

Grodner, A. and Kniesner, T. (2006). Social interactions in labor supply. Journal of the European Economic Association, 4(6):1226-1248.

Grodner, A. and Kniesner, T. (2008). Labor supply with social interactions: Econometric estimates and their tax policy implications. Research in Labor Economics, 28:1-23.

Haisken-DeNew, J. and Hahn, M. (2006). Panelwhiz: A flexible modularized stata interface for accessing large scale panel data sets. Retrieved from http: //panelwhiz. com/.

Hall, R. (1978). Stochastic implications of the life cycle-permanent income hypothesis: Theory and evidence. Journal of Political Economy, 86(6):971-987.

Hashimoto, M. (1981). Firm-specific human capital as a shared investment. American Economic Review, 71(3)(3):475-482.

Hausman, J. and Ruud, P. (1984). Family labor supply with taxes. American Economic Review, 74(2):242-248.

Holst, E. (2009). Full-time workers want to work fewer hours, part-time workers want to work longer hours. Weekly Report No. 19/2009, DIW Berlin.

Hotz, J., Kydland, F., and Sedlacek, G. (1988). Intertemporal preferences and labor supply. Econometrica, 56(2):335-360.

Jermann, U. (1998). Asset pricing in production economies. Journal of Monetary Economics, 41(2):257-275.

Johnson, T. and Pencavel, J. (1984). Dynamic hours of work functions for husbands, wives, and single females. Econometrica, 52(2):363-390.

Kahn, S. and Lang, K. (1991). The effect of hours constraints on labor supply estimates. Review of Economics and Statistics, 73(4):605-611.

Kahn, S. and Lang, K. (1992). Constraints on the choice of work hours. Journal of Human Resources, 27(4):661-678.

Kahn, S. and Lang, K. (1995). The causes of hours constraints: evidence from Canada. Canadian Journal of Economics, 28(4a):914-928.

Kahneman, D., Krueger, A., Schkade, D., Schwarz, N., and Stone, A. (2004). A survey method for characterizing daily life experience: The day reconstruction method. Science, 306(5702):1776-1780.

Kapteyn, A. (1977). A theory of preference formation. PhD thesis, Rijksuniversiteit Leiden. 
Keuzenkamp, S., Hillebrink, C., Portegijs, W., and Pouwels, B. (2009). Working part-time: (not) a problem? The Netherlands Institute for Social Research.

Killingsworth, M. (1983). Labor Supply. Cambridge University Press.

Krueger, A., Kahneman, D., Fischler, C., Schkade, D., Schwarz, N., and Stone, A. (2009). Time use and subjective well-being in France and the U.S. Social Indicators Research, 93(1):7-18.

Lazear, E. (1979). Why is there mandatory retirement? Journal of Political Economy, 87(6):1261-1284.

Lazear, E. (1981). Agency, earnings profiles, productivity, and hours restrictions. American Economic Review, 71(4):606-620.

Loog, B., Dohmen, T., and Vendrik, M. (2011). Meer of minder werken: Heterogeniteit onder werkende vrouwen. TPEdigitaal, 5(4):50-63.

Loog, B., Dohmen, T., and Vendrik, M. (2013). The scope for increasing total hours worked. De Economist, 161(2):157-174.

Manski, C. (1993). Identification of endogenous social effects: The reflection problem. Review of Economic Studies, 60(3):531-542.

Maurin, E. and Moschion, J. (2009). The social multiplier and labor market participation of mothers. American Economic Journal: Applied Economics, 1(1):251-272.

Mayraz, G., Wagner, G., and Schupp, J. (2009). Life satisfaction and relative income: Perceptions and evidence. IZA DP No. 4390.

Mehra, R. and Prescott, E. (1985). The equity premium: A puzzle. Journal of Monetary Economics, 15(2):145-161.

Mincer, J. (1963). Labor force participation of married women. In Aspects of Labor Economics. National Bureau of Economic Research.

Ministry of Social Affairs (2008). Instellingsbesluit Taskforce DeeltijdPlus. Staatscourant, 71:13.

Pollak, R. (1970). Habit formation and dynamic demand functions. Journal of Political Economy, 78(4):745-763.

Pollak, R. (1976). Interdependent preferences. American Economic Review, 66(3):309-320.

Portegijs, W., Cloïn, M., Keuzenkamp, S., Merens, A., and Steenvoorden, E. (2008). A picture of part-time working. The Netherlands Institute for Social Research.

Scherpenzeel, A. (2011). Data collection in a probability-based internet panel: How the liss panel was built and how it can be used. Bulletin of Sociological Methodology, 109(1):56-61.

Smulders, P. and de Feyter, M. (2001). Gewenste arbeidsduur, deeltijdbeleid van bedrijven en beïnvloedende factoren. Tijdschrift voor Arbeidsvraagstukken, 17(2):119-137.

Statistics Netherlands (2009). Arbeidsparticipatie in Nederland behoort tot de top van de EU. Retrieved from http://www.cbs.nl/nl-NL/menu/themas/arbeidsociale-zekerheid/publicaties/artikelen/archief/2009/2009-2819-wm.htm, May 4, 2010.

Statistics Netherlands (2011). Arbeidsrekeningen. 
Stewart, M. and Swaffield, J. (1997). Constraints on the desired hours of work of British men. Economic Journal, 107(441):520-535.

Task Force Part-time Plus (2008). One plus one is three: Work plan for the task force part time plus. Retrieved from http://www.detaskforcedeeltijdplus.nl/, November 17, 2009. Currently (November 13, 2013) available from: http://www.rijksoverheid.nl/bestanden/documentenen-publicaties/kamerstukken/2008/07/01/werkplan-taskforce-deeltijdplus/352008-3-11998.pdf).

Task Force Part-time Plus (2010). De discussie voorbij: Eindrapport Taskforce DeeltijdPlus. Den Haag: Ministerie van Sociale Zaken en Werkgelegendheid.

Tijdens, K. (2000). Vraag en aanbod van huishoudelijke diensten in Nederland. Amsterdams Instituut voor Arbeidsstudies, Amsterdam.

Tversky, A. and Kahneman, D. (1974). Judgment under uncertainty: Heuristics and biases. Science, 185(4157):1124-1131.

Van Lomwel, G. and Van Ours, J. (2005). On the employment effects of part-time labor. De Economist, 153(4):451-460.

Vendrik, M. (1993). Habits, hysteresis and catastrophes in labor supply. Journal of Economic Behavior and Organization, 20(3):353-372.

Vendrik, M. (1998). Unstable bandwagon and habit effects on labor supply. Journal of Economic Behavior and Organization, 36(2):235-255.

Vendrik, M. (2003). Dynamics of a household norm in female labour supply. Journal of Economic Dynamics and Control, 27(5):823-841.

Weinberg, B., Reagan, P., and Yankow, J. (2004). Do neighborhoods affect hours worked? Evidence from longitudinal data. Journal of Labor Economics, 22(4):891-924.

Woittiez, I. and Kapteyn, A. (1998). Social interactions and habit formation in a model of female labour supply. Journal of Public Economics, 70(2):185-205.

Wooden, M., Warren, D., and Drago, R. (2009). Working time mismatch and subjective well-being. British Journal of Industrial Relations, 47(1):147-179. 



\section{Samenvatting (Summary in Dutch)}

\section{Het proefschrift}

Dit proefschrift is geschreven rondom de vraag hoeveel uur per week werkende mensen willen werken. Hierbij schenken we aandacht aan twee aspecten. ${ }^{1}$ Het eerste aspect heeft betrekking op het verschil tussen het aantal uren dat personen werken en het aantal uren dat ze aangeven te willen werken. Het tweede aspect heeft te maken met de vraag hoe voorkeuren voor arbeidsduur worden gevormd.

In de eerste twee inhoudelijke hoofdstukken (Hoofdstukken 2 en 3) staat het verschil tussen het aantal gewerkte en het aantal gewenste arbeidsuren centraal. Deze hoofdstukken zijn beschrijvend van aard, en geven inzicht in hoe personen met verschillende kenmerken van elkaar verschillen met betrekking tot de wens om meer of minder uren per week te willen werken.

In de laatste twee inhoudelijke hoofdstukken (Hoofdstukken 4 en 5) worden fundamentelere vragen beantwoord omtrent de vorming van de voorkeuren met betrekking tot de wekelijkse arbeidsduur. In dit afsluitende hoofdstuk worden de resultaten van de in dit proefschrift gepresenteerde analyses samengevat en besproken.

\section{Hoofdstuk 2}

In Hoofdstuk 2 wordt bekeken hoe werkende vrouwen in Nederland aankijken tegen hun wekelijkse arbeidsduur. De aanleiding voor dit onderzoek was de wens van het

\footnotetext{
${ }^{1}$ Hoewel uitsluitend mijn naam op de voorkant van dit boekje staat, schrijf ik hier en in de rest van het proefschrift bewust 'we'. 'We', omdat een groot deel van dit proefschrift gebasseerd is op samenwerking met Thomas Dohmen en Maarten Vendrik.
} 
toenmalige kabinet (Balkenende IV) dat vrouwen meer uren zouden gaan werken (Ministerie van Sociale Zaken en Werkgelegenheid, 2008). In dit hoofdstuk wordt daarom specifiek onderzocht in hoeverre werkende vrouwen in Nederland meer of minder uren willen werken, en hoe de verschillen tussen de feitelijke en gewenste uren afhangen van persoonskenmerken, zoals het opleidingsniveau, leeftijd, en de positie in het huishouden. Doel daarvan is om te onderzoeken of het verstandig is alle werkende vrouwen te stimuleren om meer uren per week te gaan werken.

Met behulp van informatie afkomstig uit een internetpanel wordt de wens om meer of juist minder uren te werken in beeld gebracht. Uit de resultaten blijkt dat reeds een groot deel van de werkende vrouwen in Nederland juist minder uren wil werken, maar dat er ook een groep bestaat (kleiner in omvang) die juist meer uren wil werken. ${ }^{2}$ Interessant om te zien is dat deze twee groepen met betrekking tot achtergrondkenmerken duidelijk van elkaar verschillen. De eerste groep bestaat voor meer dan de helft uit hoger opgeleiden (hbo en wo) die op het moment van het invullen van de vragenlijst ook meer uren per week werkten, gemiddeld 34 uur. $^{3}$ De tweede groep bestaat voor minder dan een kwart uit hoger opgeleiden en heeft vaker ten hoogste een vmbo opleiding afgerond, werkt doorgaans minder uren (21 uur per week), en heeft in eenvijfde van de gevallen ongeschoold of laaggeschoold werk.

Uit deze resultaten volgt dat het laten toenemen van de arbeidsduur onder werkende vrouwen voor een groot deel van de vrouwen geen punt van discussie lijkt, omdat zij zelfs minder willen werken dan ze al doen. Voor een ander deel van de groep is het ook niet zozeer een punt van discussie, maar is het probleem eerder dat men wel meer wil werken, maar dit mogelijk niet gerealiseerd krijgt. In Hoofdstuk 2 wordt daarom beargumenteerd dat bij het maken van beleid deze verschillen in achtergrondkenmerken en gewenste arbeidsduur op een juiste manier in beschouwing genomen moeten worden. Voor de ene groep is het belangrijk te achterhalen waar de problemen zitten met betrekking tot de wens om de arbeidsduur uit te breiden, terwijl er bij de andere groep in eerste instantie moet worden achterhaald welke mogelijkheden er zijn om het aantal gewerkte uren niet te doen afnemen.

\section{Hoofdstuk 3}

In Hoofdstuk 2 ligt de nadruk op hoe personen met verschillende achtergrondkenmerken hun arbeidsduur zouden willen aanpassen. In Hoofdstuk 3 ligt de nadruk op de wens om meer of minder uren te werken binnen groepen personen met vergelijkbare kenmerken. Het uitgangspunt van de analyse in Hoofdstuk 3 is eerder onderzoek van Booth and Van Ours (2013) waaruit blijkt

\footnotetext{
${ }^{2}$ Men heeft antwoord gegeven op de vraag: "Hoeveel uren per week zou u in totaal willen werken? Het gaat om het aantal uren in alle banen die u hebt, bij elkaar genomen."

${ }^{3}$ De onderliggende cijfers zijn te vinden in Tabel 2.1.
} 
dat personen die relatief weinig uren werken hun arbeidsduur doorgaans willen verhogen, terwijl mensen die relatief veel uren werken, hun arbeidsduur vaker willen laten afnemen. Ergens tussen deze twee uitersten in bestaat er een aantal uren per week waarbij men gemiddeld genomen niet meer of minder uren wil werken. Het werk van Booth en Van Ours toont aan dat dit 'evenwicht' voor gehuwde en samenwonende vrouwen in Nederland rond de 21 uur per week ligt. ${ }^{4}$

In Hoofdstuk 3 laten we in het eerste deel van de analyse zien dat het punt waarbij men de arbeidsduur gemiddeld genomen niet wil aanpassen afhangt van achtergrondkenmerken. Zo ligt het hierboven beschreven 'evenwicht' voor ongeschoolde of laaggeschoolde vrouwelijke werknemers in de leeftijd van 16 tot 35 jaar bij ongeveer vier voltijddagen (32 uur per week). Bij 55-plussers die geschoolde arbeid verrichten ligt dit 'evenwicht' bij ongeveer 16 uur per week. Dit betekent dat bij een arbeidsduur tot aan 32 uur per week personen in de eerstgenoemde groep gemiddeld genomen meer uren willen werken. Voorbij de 32 uur verandert dit (gemiddeld genomen) in een wens om de arbeidsduur te laten afnemen. Bij de laatstgenoemde groep doet dit zich al voor vanaf 16 uur per week. Het 'evenwicht' met betrekking tot gewerkte uren hangt dus af van achtergrondkenmerken.

In het tweede deel van de analyse wordt bekeken hoe de verdeling van de arbeidsduur eruit ziet binnen groepen met verschillende achtergrondkenmerken. Wanneer een groot aandeel van de personen binnen een bepaalde groep minder uren werkt dan het 'evenwicht' behorende bij die groep, betekent dit dat (wederom, gemiddeld genomen) personen binnen die groep vaak de wens zullen hebben om hun arbeidsduur uit te breiden. Het stimuleren van het arbeidsaanbod bij een dergelijke groep zal weinig effect hebben op het aantal gewerkte uren van een dergelijke groep, aangezien een groot deel van de personen binnen een dergelijke groep de arbeidsduur reeds wil uitbreiden.

De resultaten van Hoofdstuk 3 laten dus zien dat de wens om de arbeidsduur te veranderen niet alleen verschilt tussen groepen met verschillende achtergrondkenmerken (Hoofdstuk 2), maar dat het verschil in de abeidsduur binnen die groepen ook in ogenschouw moet worden genomen.

\section{Hoofdstuk 4}

In Hoofdstuk 4 wordt onderzocht of voorkeuren met betrekking tot de wekelijkse arbeidsduur worden beïnvloed door zogenaamde referentie-effecten. Verschilende theorieën voorspellen namelijk dat de eigen arbeidsduur (gewoontevorming) en/of de arbeidsduur van andere personen in een referentiegroep (interpersonele

\footnotetext{
${ }^{4}$ Het gaat hierbij niet om een evenwicht zoals dat doorgaans in de economische theorie besproken wordt, namelijk een situatie waarin geen van de personen zijn of haar manier van handelen zou willen aanpassen, gegeven het handelen van de andere personen in de economie.
} 
afhankelijkheid van voorkeuren) van invloed kunnen zijn op de vorming van de voorkeuren van een individu. ${ }^{5}$

Om een dergelijke onderzoeksvraag te beantwoorden is doorgaans een experiment nodig. Dat wil zeggen: Idealiter zouden we mensen in een laboraturiumsetting plaatsen, en vervolgens hun arbeidsduur veranderen. Vervolgens zou onderzocht kunnen worden of en hoe de verandering van de arbeidsduur de voorkeuren verandert. Het is echter heel lastig (en onethisch, bovendien) om mensen te dwingen een exact aantal uren per week te werken. In Hoofdstuk 4 maken we daarom gebruik van een zogenoemd natuurlijk experiment. In dat experiment verandert de lengte van de standaardwerkweek van ambtenaren (Beamte) en werknemers (Angestellte) van de Duitse overheid. In het hoofdstuk wordt onderzocht in hoeverre deze verandering in wetgeving de voorkeuren met betrekking tot gewenste uren heeft beïnloed.

De resultaten laten zien dat de standaardwerkweek, bovenop de leeftijd, het uurloon en de huishuidsamenstelling, een significante invloed heeft op de gewenste wekelijkse arbeidsduur. Helaas is het aan de hand van de data die we tot onze beschikking hebben niet mogelijk om exact te achterhalen welke van de verschillende door de theorie voorspelde mechanismen het effect van de standaardwerkweek op de gewenste arbeidsduur verklaren. Zo voorspelt de theorie van de gewoontevorming dat een verandering van de eigen arbeidsduur leidt tot een verandering van de voorkeuren met betrekking tot diezelfde arbeidsduur. De theorie van de interpersonele afhankelijkheid van voorkeuren (IAV) voorspelt dat een verandering van de arbeidsduur van een referentiegroep, bijvoorbeeld collega's, een direct effect heeft op individuele voorkeuren. Omdat men doorgaans als groep collega's getroffen wordt door een verandering in de standaardwerkweek, en nooit als individu, is het lastig om binnen een groep collega's (zoals Beamte of Angestellte) het potentiële effect van gewoontevorming te onderscheiden van het effect van IAV.

\section{Hoofdstuk 5}

Zoals besproken in de vorige paragraaf is het lastig om te achterhalen hoe het mechanisme, of de combinatie van mechanismen, achter het effect van de standaardwerkweek op de voorkeuren voor de arbeidsduur exact werkt. Eén van de mogelijke mechanismen is interpersonele afhankelijkheid van voorkeuren (IAV). Dit betekent dat de arbeidsduur van personen in iemands referentiegroep een direct effect heeft op de voorkeuren met betrekking tot de arbeidsduur van die persoon.

In Hoofdstuk 5 wordt onderzocht of de voorkeuren met betrekking tot de arbeidsduur van personen die zelf geen verandering in de standaardwerkweek

\footnotetext{
${ }^{5}$ In het inhoudelijke hoofdstuk en het conclusiehoofdstuk worden verschillende andere mogelijke manieren besproken waarop een dergelijke verandering van de (standaard) arbeidsduur van invloed kan zijn op voorkeuren.
} 
ondergaan worden beïnvloed door de arbeidsduur van collega's, die wel een dergelijke verandering ondergaan. Hierbij wordt gebruik gemaakt van het feit dat Beamte (ambtenaren) en Angestellte (andere werknemers in het publieke domein) onder andere regelgeving vallen met betrekking tot de lengte van de standaardwerkweek, maar wel vaak collega's zijn. Zo kon er in de periode tussen 2003 en 2009 dus een situatie ontstaan waarin Beamte wel een verandering van de standaardwerkweek ondergingen, terwijl een dergelijke verandering voor Angestellte niet gold.

Door dit verschil in regelgeving hebben we kunnen onderzoeken in hoeverre de voorkeuren van Angestellte hebben gereageerd op een verandering van de gewerkte uren van Beamte, zonder dat zij zelf veranderingen in hun arbeidsduur ondergingen. Dit is een interessant vraagstuk, omdat hier één van de andere mogelijke verklaringen van de relatie tussen de standaardwerkweek en de voorkeuren met betrekking tot gewenste uren, namelijk gewoontevorming, kan worden uitgesloten als verklaring.

De resultaten laten zien dat een verandering van de standaardwerkweek van Beamte heeft geleid tot een toename van hun arbeidsduur en dat deze toename in de arbeidsduur van de groep Beamte heeft geleid tot een kleine verhoging in de gewenste arbeidsduur van Angestellte. 



\section{Curriculum Vitae}

Bart Loog was born on 6 March 1986 in Hoensbroek, the Netherlands. After graduating from Sint-Janscollege in Hoensbroek he started studying economics at Maastricht University in 2004, where he received his Master of Science degree in International Economic Studies in September 2008, with a major in Behavioral Economics.

After a year of course work in applied econometrics and working as a student assistant at Statistics Netherlands (CBS), Bart returned to Maastricht University as a $\mathrm{PhD}$ candidate at the Department of Economics of the School of Business and Economics in September 2009. The results of his work as a doctoral candidate are collected in this dissertation. His research has been presented at various conferences, including the 2012 meetings of the European Society of Population Economics (Bern, Switzerland), the European Economic Association (Málaga, Spain) and the European Association of Labour Economists (Bonn, Germany). Two of the chapters in this dissertation, Chapter 1 (Loog et al., 2011) and Chapter 2 (Loog et al., 2013), were published earlier.

In November 2012, after teaching for two months, Bart left Maastricht University to become a researcher at Statistics Netherlands in the sector 'Labour, income and quality of life statistics' of the division 'Socio-economic and spatial statistics'. 


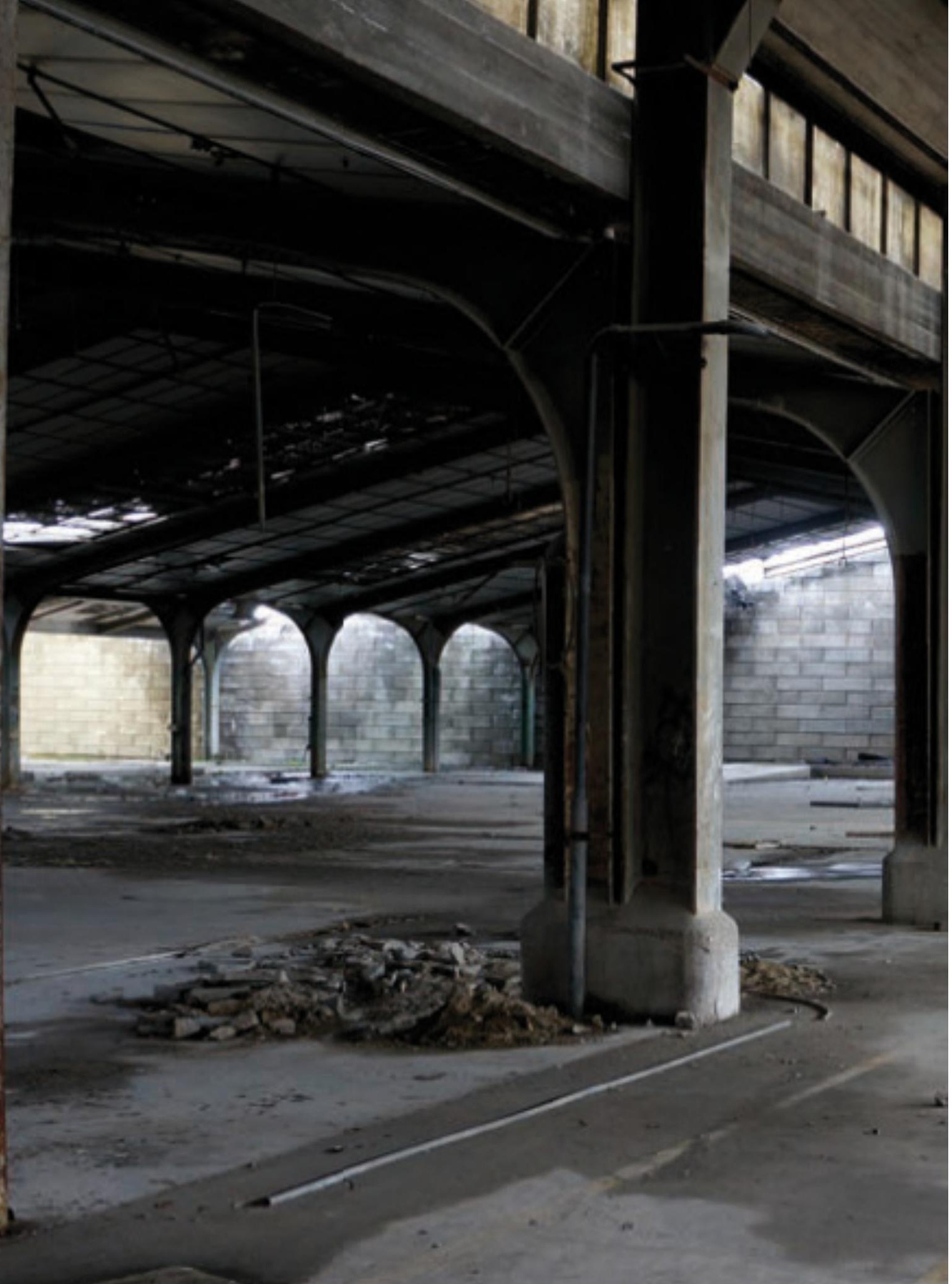

